US Army Corps

of Engineers ${ }_{\circledast}$

Engineer Research and

Development Center

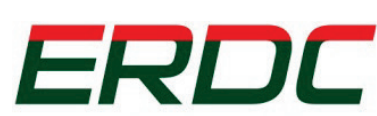

INNOVATIVE SOLUTIONS

for a safer, better world

Wetlands Regulatory Assistance Program

\title{
Evaluation of Wetland Hydrology in Formerly Irrigated Areas
}

Jacob F. Berkowitz, Jason P. Pietroski, and Steven J. Currie

July 2017
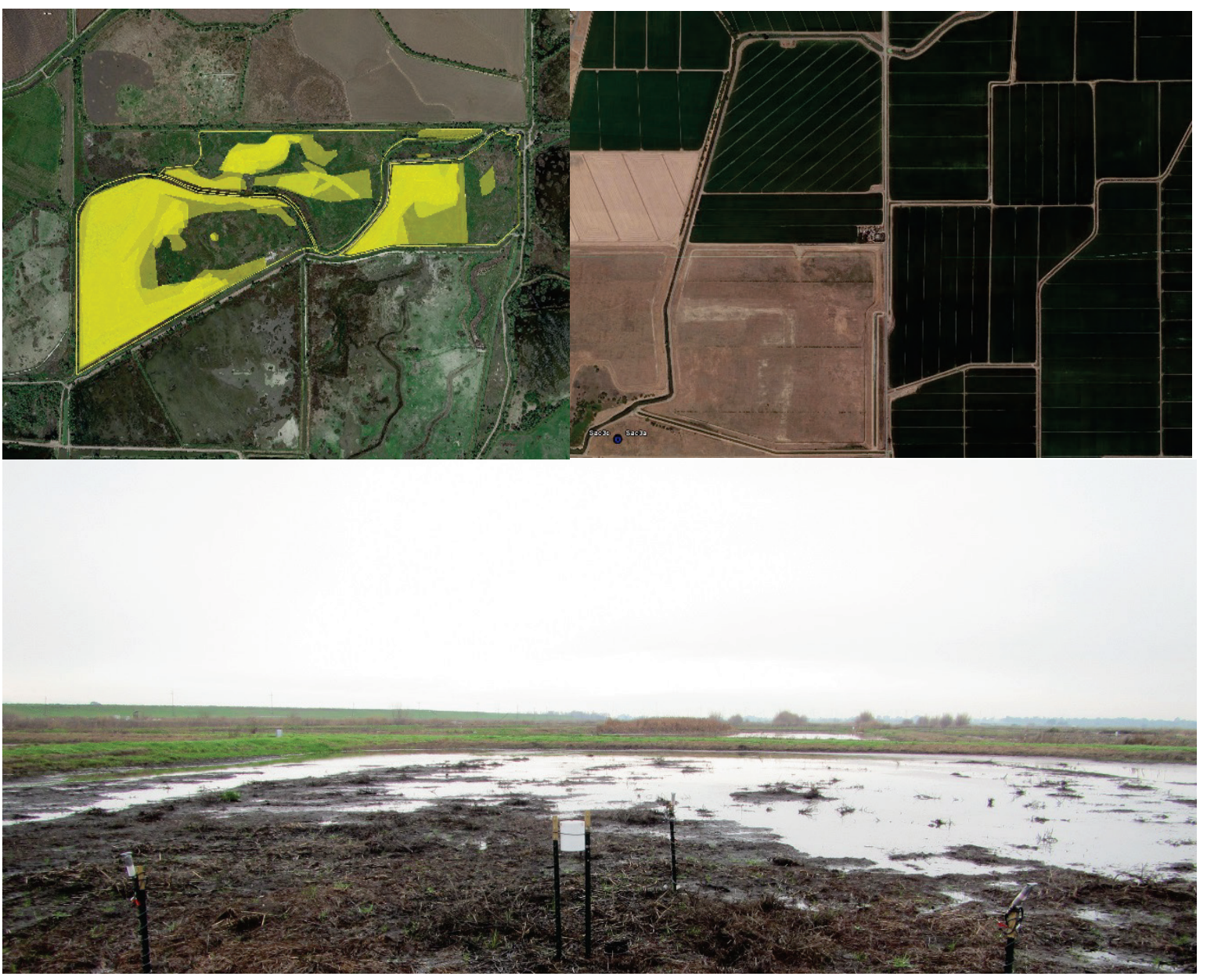
The U.S. Army Engineer Research and Development Center (ERDC) solves the nation's toughest engineering and environmental challenges. ERDC develops innovative solutions in civil and military engineering, geospatial sciences, water resources, and environmental sciences for the Army, the Department of Defense, civilian agencies, and our nation's public good. Find out more at www.erdc.usace.army.mil.

To search for other technical reports published by ERDC, visit the ERDC online library at http://acwc.sdp.sirsi.net/client/default. 


\section{Evaluation of Wetland Hydrology in Formerly Irrigated Areas}

Jacob F. Berkowitz, Jason P. Pietroski, and Steven J. Currie

Environmental Laboratory

U.S. Army Engineer Research and Development Center

3909 Halls Ferry Road

Vicksburg MS 39180

Final report

Approved for public release; distribution is unlimited.

Prepared for U.S. Army Corps of Engineers

Washington, DC 20314-1000

Under Project A1360 Technical Guidance for Irrigated Wetlands 


\section{Abstract}

The application of irrigation waters has the potential to alter soil morphology, patterns of hydrology, and the distribution of plant communities. As a result, the identification of wetlands in irrigated areas remains challenging. The following report is the first to evaluate the capacity of wetland hydrology to persist following the cessation of external water inputs for the purposes of wetland identification. Twelve of the thirteen study locations examined met the established criteria for wetland identification. The spatial extent of wetland hydrology was determined onsite and compared to estimates based upon an analysis of aerial imagery. Findings suggest that aerial image interpretation provides a useful, but conservative approach to identifying areas of wetland hydrology in formerly irrigated areas. A framework is proposed to support wetland delineations conducted in formerly irrigated areas incorporating off-site evaluations, site visits conducted during the regular wet portion of the year, and analysis of rainfall normality.

DISCLAIMER: The contents of this report are not to be used for advertising, publication, or promotional purposes. Citation of trade names does not constitute an official endorsement or approval of the use of such commercial products. All product names and trademarks cited are the property of their respective owners. The findings of this report are not to be construed as an official Department of the Army position unless so designated by other authorized documents. 


\section{Contents}

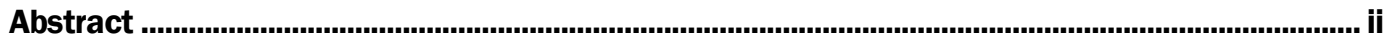

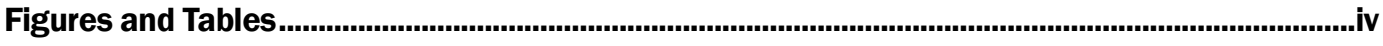

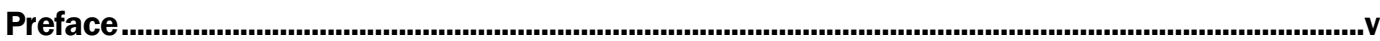

Executive Summary .......................................................................................................................

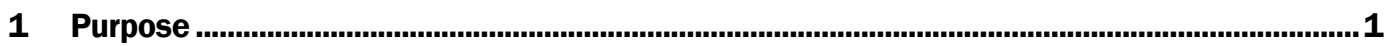

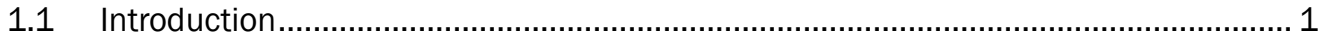

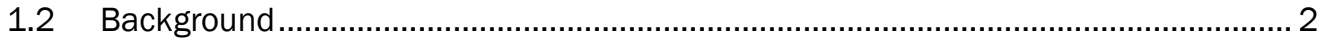

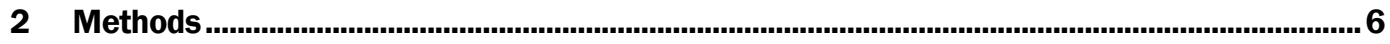

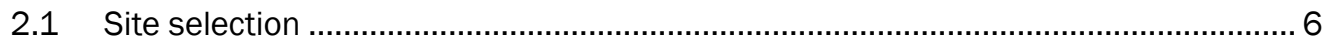

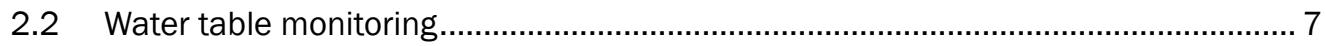

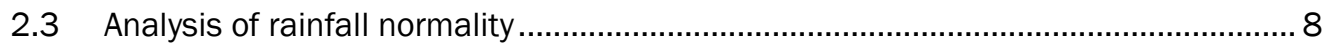

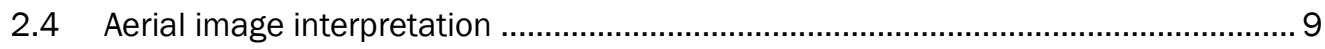

3 Results and Discussion ........................................................................................................10

3.1 Water table measurements .............................................................................. 10

3.2 Rainfall normality........................................................................................... 16

3.3 Application of the Technical Standard for Water-Table Monitoring of Potential Wetland Sites (TSWTM) ................................................................................ 19

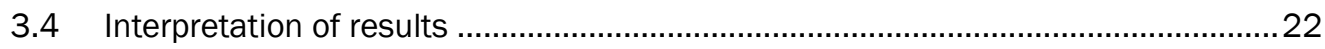

3.5 Framework for wetland delineation in formerly irrigated areas ..............................22

4 Summary..................................................................................................................................25

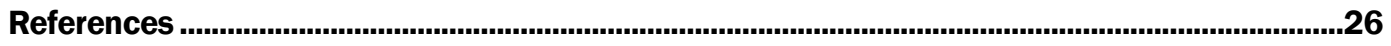

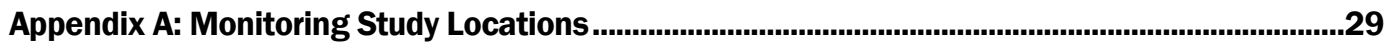

Appendix B: Results Aerial Image Interpretation and Field Verification .........................................35

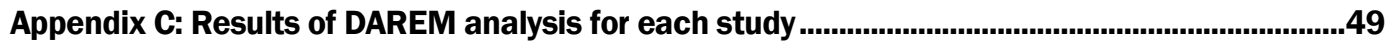

\section{Report Documentation Page}




\section{Figures and Tables}

\section{Figures}

Figure 1. Study locations within MLRA 16 (left) and 17 (right).

Figure 2. Schematic of monitoring well installation (left; USACE 2005) and deployment of automated data logger during fall 2015 (right).

Figure 3. Example ground water and rainfall monitoring data at T1. Note the response of groundwater levels to rainfall events. Dashed line represents 12 inches below ground surface (BGS).

Figure 4. Groundwater and precipitation patterns at study location A4. Note that early season rainfall events increase soil moisture and shallow groundwater elevation prior to the onset of wetland hydrologic conditions in which water tables reach the upper portion of the soil profile. Dashed line represents 12 inches (BGS).

Figure 5. Water table monitoring data at study location A5, which was adjacent to an irrigation ditch. Asterisks indicate high water table events associated with periods when water was observed in the irrigation ditch. Precipitation driven high water tables occurred during March, an extended period when no water was present in the irrigation ditch. Dashed line represents 12 inches (BGS).

Figure 6. Water budget for Sacramento, CA (WebWIMP 2003).

Figure 7. Palmer drought severity index during October 2015, the first month of water table monitoring.

Figure 8. A2 site visit photograph depicting high water table and surface soil saturation in lower elevation portion of study area.

Figure 9. Comparison of wetland extent as determined by image interpretation (left) and on-site verification (right).

\section{Tables}

Table 1. Study area location, size, irrigation cessation year, and cropping history. . 7

Table 2. Results of ground water monitoring conducted in formerly irrigated areas. ........................10

Table 3. Mapped soil series information for each sample location (Soil Survey Staff 2016)............15

Table 4. Rainfall data collected during the study period. ....................................................................16

Table 5. Monthly DAREM analysis results during the monitoring period...........................................16

Table 6. Palmer Drought Severity Index ratings 2013-2016. Monitoring period data in italics.

Table 7. Comparison of off-site and field verified spatial extent of wetland hydrology. 


\section{Preface}

This study was conducted for the Wetlands Regulatory Assistance Program under A1360 "Technical Guidance for Irrigated Wetlands." Funding was provided by the USACE Wetlands Regulatory Assistance Program (Ms. Sally Stroupe, Program Manager).

The work was performed by the Wetlands and Coastal Ecology Branch (EEW) of the Ecosystem Evaluation and Engineering Division (EE), U.S. Army Engineer Research and Development Center, Environmental Laboratory (ERDC-EL). At the time of publication: Ms. Patty Tolley was Chief, CEERDEE-W; Mr. Mark Farr was Chief, CEERD-EE; and Dr. Al Cofrancesco, CEERD-EM-W was the Technical Director. The Deputy Director of ERDCEL was Dr. Jack Davis and the Director was Dr. Beth Fleming.

The authors would like to thank the following organizations and individuals for granting access, allowing installation of monitoring equipment, and other assistance: Mr. Mark Morse (Environmental Coordinator - City of Roseville, CA), Mr. John Roberts (Executive Director - Natomas Basin Conservancy), Mr. Jeremy Lor (Field Assistant - Natomas Basin Conservancy), Mr. Bryan Brock (Senior Engineer - California Department of Water Resources), Mr. Andy Atkinson and Mr. Dave VanBaren (Senior Environmental Specialist and Environmental Specialist - California Department of Fish and Wildlife/Gray Lodge Wildlife Area), and Mr. Jeffrey Prentice and Mr. David Jernigan (Wildlife Biologists - Sacramento International Airport). Without your help this project and the development of this Technical Report would not have been possible.

The authors also acknowledge Mr. James Robb (USACE Sacramento District) who provided significant assistance with site access and field data collection. Mr. Thomas Cavanaugh and Mr. Wade Eakle (USACE South Pacific Division) also provided valuable insight regarding the project. Mr. Kevin Philley, Mr. Darrell Evans, and staff members from USACE SPD and Sacramento District, including Mr. Michael Jewell (Regulatory Chief), provided logistical support and technical review of the document. Mr. Michael Finan was instrumental in the development of this project, providing mentorship, and a wealth of knowledge; he expanded the understanding of wetland resources in the region.

The Commander of ERDC was COL Bryan S. Green and the Director was Dr. David W Pittman. 


\section{Executive Summary}

The application of irrigation waters has the potential to alter soil morphology, patterns of hydrology, and the distribution of plant communities. As a result, the identification of wetlands in areas formerly receiving irrigation remains challenging. The following report is the first to evaluate the capacity of wetland hydrology to persist in irrigated areas following the cessation of external water inputs for the purposes of wetland identification. Hydrology was monitored in 13 formerly irrigated croplands to determine if study areas met the U.S. Army Corps of Engineers (USACE) Technical Standard for Water-Table Monitoring of Potential Wetland Sites (TSWTM). Periods of continuous near surface saturation ranged from 9-37 days (average $\pm \mathrm{SE}=20.8 \pm 2.0$ days). Additionally, rainfall normality was evaluated, demonstrating that high water table events occurred during periods of normal or below normal rainfall. Twelve of the thirteen study locations met the TSWTM and the established criteria for wetland identification. One site failed to meet the TSWTM due to water tables dropping below 12 inches one 24 hour period. However, persistent surface water and soil saturation were documented on portions of the study location, highlighting the importance of monitoring well placement. The spatial extent of wetland hydrology was determined during site visits and compared to estimates based upon an analysis of aerial imagery. No difference in the acreage of wetland hydrology was detected between on-site monitoring and image interpretation approaches at five locations. The acreage of wetland hydrology was underestimated utilizing off-site approaches at the remaining eight sites, likely due to the difficulty in identifying saturated soil conditions using off-site sources. The findings suggest that aerial image interpretation provides a useful, but conservative approach to identifying areas of wetland hydrology in formerly irrigated areas. Based on these observations, a framework is proposed to support wetland delineations conducted in formerly irrigated areas incorporating off-site evaluations, site visits conducted during the regular wet portion of the year, and analysis of rainfall normality. In some cases, on-site monitoring of wetland hydrology may be required to further refine wetland boundaries. Additionally, this procedure has proven to be effective for evaluating hydrology and assisting with the identification and delineation of a variety of wetland types in multiple land use scenarios. The information generated is a valuable tool to further document the administrative record in support of wetland determinations. 


\section{Purpose}

The following report addresses challenges associated with wetland determinations conducted in areas affected by irrigation inputs. The document outlines recommendations within existing guidance documents and discusses background information regarding efforts to support wetland delineation in areas receiving irrigation water. The results of a study conducted to evaluate the capacity of wetlands to persist in the absence of irrigation inputs are also presented, including an evaluation of the use of aerial image interpretation. Additionally, a framework for conducting wetland determinations in formerly irrigated areas is provided.

\subsection{Introduction}

The U.S. Army Corps of Engineers (USACE) is responsible for administering Section 404 of the Clean Water Act, which regulates the discharge of dredged or fill material into waters of the U.S., including wetlands and other aquatic resources. As part of the permitting process, aquatic resources within a project area must be identified and mapped. As such, wetland delineation is required to determine the extent of federal jurisdiction, if the proposed activity is regulated, the proposed acreage of jurisdictional aquatic resource impact, and the associated regulatory permitting requirements.

Wetlands are identified based upon the observation of indicators of wetland hydrology, hydrophytic vegetation, and hydric soils (Environmental Laboratory 1987; USACE 2008). Long term irrigation has the potential to alter these indicators. In some cases, wetland indicators may be created and maintained solely, or in part by, the application of irrigation waters (USACE 2008; 2010). According to the 1986 preamble to 33 CFR Part 328.3 (51 FR 41217), the USACE generally does not consider artificially irrigated areas which would revert to uplands if the irrigation ceased to be waters of the United States under Section 404 of the Clean Water Act. However, it remains difficult to distinguish wetlands that would persist from those relying solely on irrigation under normal circumstances (Environmental Laboratory 1987).

The USACE requires defensible documentation identifying the presence or absence of wetland conditions when agricultural lands receiving irrigation 
water are converted to other land uses. This includes areas in the arid west region where irrigation has been practiced for more than 125 years, changing natural hydrology regimes over large areas (Department of Ecology 2010). The impact of irrigation water applications has been shown to alter vegetation and soil characteristics (e.g., color, redox features, and salt content) of affected areas (Ekstein and Hygnstrom 1996; Sueltenfuss et al. 2013; Kendy and Bredehoeft 2006; Strange et al. 1999). Long-term irrigation of pastures, crops, and overflow of excess irrigation water into adjacent areas has been shown to create wetlands or enhance/alter pre-existing wetlands in the region (Summerford 2009).

To address these challenges, USACE developed strategies to assist with the identification of areas in which wetland conditions would persist following the removal of irrigation water inputs (USACE 2012; Berkowitz et al., 2016). Both the USACE Wetland Delineation Manual (Environmental Laboratory 1987) and associated regional supplements provide guidance on conducting wetland delineations in disturbed and problematic areas, including in irrigated agricultural areas (USACE 2008). In 2012, the USACE South Pacific Division (SPD) developed guidelines encouraging landowners to discontinue application of irrigation inputs for one or more years (USACE 2012). Additionally, this guidance recommends assessing hydrology during the wet or non-irrigated season, evaluating rainfall normality, examining aerial imagery, installation of groundwater monitoring wells, and establishing reference sites if necessary.

The examination of wetland hydrology in the absence of water additions in combination with analysis of rainfall normality provides a technically sound approach to making wetland determinations in irrigated areas (USACE 2012). However, limited data exist from which to develop technical guidance to aid in the identification of wetlands that would persist in the absence of irrigation inputs (Berkowitz and Evans 2014; Berkowitz et al., 2016). As a result, the identification of wetlands in formerly irrigated areas remains difficult, even in the absence of irrigation inputs, because hydrophytic vegetation may persist for several years and hydric soil features can remain decades after changes to site hydrology have occurred (Environmental Laboratory 1987; Vepraskas and Vaughn 2016).

\subsection{Background}

In order to address the challenges associated with identifying wetlands in irrigated areas, a multi-year investigation was developed to provide 
technical support regarding irrigated wetland issues. The project included publication of a literature review which examined available information on irrigated wetland distribution and geographic range; regulatory status; creation in agricultural landscapes; wildlife habitat; threatened and endangered species; water quality; hydrology, soils, and vegetation (Berkowitz and Evans 2014). The review documented a paucity of data supporting technical approaches to wetland delineation in irrigated wetlands. Also, the likelihood that wetland characteristics would persist in the absence of irrigation supplemented hydrology was not adequately addressed.

Due to the challenges outlined above, in which indicators of hydrophytic vegetation, hydric soils, and wetland hydrology may show signs of potential alteration, wetland determinations in formerly irrigated areas must rely on the best available information (USACE 2008). In most cases, this results in additional emphasis being placed on the capacity for wetland hydrology to remain intact in the absence of irrigation inputs (USACE 2012). An approach that focuses on wetland hydrology is applied because once established, field indicators of hydric soil and hydrophytic vegetation may be unreliable in the years following the removal of irrigation applications. For example, the Regional Supplement to the Corps of Engineers Wetland Delineation Manual: Arid West Region (Version 2.0) (USACE 2008) states the following in the discussion of problematic hydric soil determinations:

The application of irrigation water to upland areas can create wetland hydrology and, given adequate time, induce the formation of hydric soil indicators. In some cases, a soil scientist can distinguish naturally occurring hydric soil features from those induced by irrigation. Characterizing the naturally occurring hydrology is often important to the determination, and the timing of field observations can be critical. Observations made during the early part of the growing season, when natural hydrology is often at its peak and irrigation has not yet begun, may help to differentiate naturally occurring and irrigation-induced hydric soil features.

Similarly, the regional supplement provides a discussion of problematic vegetation determinations conducted in areas impacted by managed plant communities. The regional supplement instructs users to evaluate unaltered reference areas, evaluate vegetation one or more years following 
cessation of management activities, and utilize offsite sources. The regional supplement then states the following:

If the unmanaged vegetation condition cannot be determined, make the wetland determination based on indicators of hydric soil and wetland hydrology.

Further guidance has been developed by USACE (2012) including the following two statements:

Where irrigation is ongoing, wetland indicators may be the result solely of the irrigation. Therefore, discontinuing the application of irrigation water is usually the best method for determining whether or not wetland hydrology would be present under normal circumstances.

Hydrology is the most reliable, measureable, factor for making wetland determinations on irrigated land, but caution must be exercised when assessing hydrology in these areas. In areas where natural hydrology occurs only during a portion of the year, assessing hydrology during the wet or non-irrigation season may be the most reliable for making wetland determinations. The effects of irrigation may persist for some time, so it is important, when irrigation ceases, to ensure that sufficient time has passed and the observed hydrology is not an artifact of irrigation.

The guidance provided above indicates that wetland delineations in formerly irrigated wetlands should focus on determining the presence of wetland hydrology. This approach provides evidence that formerly irrigated areas continue to function as wetlands, in which hydric soil and hydrophytic plant community processes are occurring. As a result, USACE Engineer Research and Development Center (ERDC) staff developed a Technical Report outlining approaches to identify areas exhibiting potential wetland hydrology utilizing off-site tools including aerial image interpretation, Light Detection and Ranging (LiDAR), and analysis of rainfall normality (Berkowitz et al. 2016). The report concluded that evaluating multiple years of imagery can provide additional documentation for the administrative record and determine the presence, persistence, and spatial extent of wetness signatures in formerly irrigated areas. Further, constructing composite images in conjunction with analysis of rainfall normality refine 
the identification of formerly irrigated areas that contain wetlands and aid in field data collection/verification efforts.

Based upon results of the previous efforts, a field monitoring project was implemented in 2015-2016 to evaluate the potential for formerly irrigated areas to maintain wetland conditions following removal of supplemental water additions. In order to determine if wetlands and wetland hydrology persisted, the USACE Technical Standard for Water-Table Monitoring of Potential Wetland Sites (TSWTM) was evaluated at 13 locations in California (USACE 2005). The TSWTM states the following:

The site is inundated (flooded or ponded) or the water table is $\leq 12$ inches below the soil surface for $\geq 14$ consecutive days during the growing season at a minimum frequency of 5 years in $10(\geq 50 \%$ probability). Any combination of inundation or shallow water table is acceptable in meeting the 14-day minimum requirement. Shortterm monitoring data may be used to address the frequency requirement if the normality of rainfall occurring prior to and during the monitoring period each year is considered.

In addition to determining the presence or absence of wetlands at the 13 sites examined, the spatial extent of wetlands was determined during site visits. The acreage of wetlands was then compared with results from image analysis to investigate the utility and reliability of off-site sources for making wetland determinations in formerly irrigated areas when onsite monitoring remains impracticable. The current report combines onsite evaluations utilizing the TSWTM and off-site approaches via image analysis as described in Berkowitz et al. (2016); providing additional technical guidance to aid in determining the presence and extent of wetlands in formerly irrigated areas. A framework for evaluating potential wetland areas is also proposed.

The information herein supports and supplements current approaches and is not intended to replace or supersede current USACE national, division, or district level guidance for making wetland determinations in irrigated croplands. The procedures in this document should not be the sole basis for making wetland determinations for the purposes of the Clean Water Act; rather, these procedures are intended to supplement existing guidance and provide additional supporting information for making wetland determinations. 


\section{Methods}

\subsection{Site selection}

During 2015, a wide range of potential study locations were evaluated by ERDC staff and SPD along with local land managers. Study locations occurred in formerly agricultural areas near Sacramento, CA. All study areas were found within Land Resource Region C - California Subtropical Fruit, Truck, and Specialty Crop Region; with 12 study locations located within Major Land Resource Area (MLRA) 17 - Sacramento and San Joaquin Valleys and one study location in MLRA 16 - California Delta (USDA-NRCS 2006; Figure 1; Appendix A).

Figure 1. Study locations within MLRA 16 (left) and 17 (right).
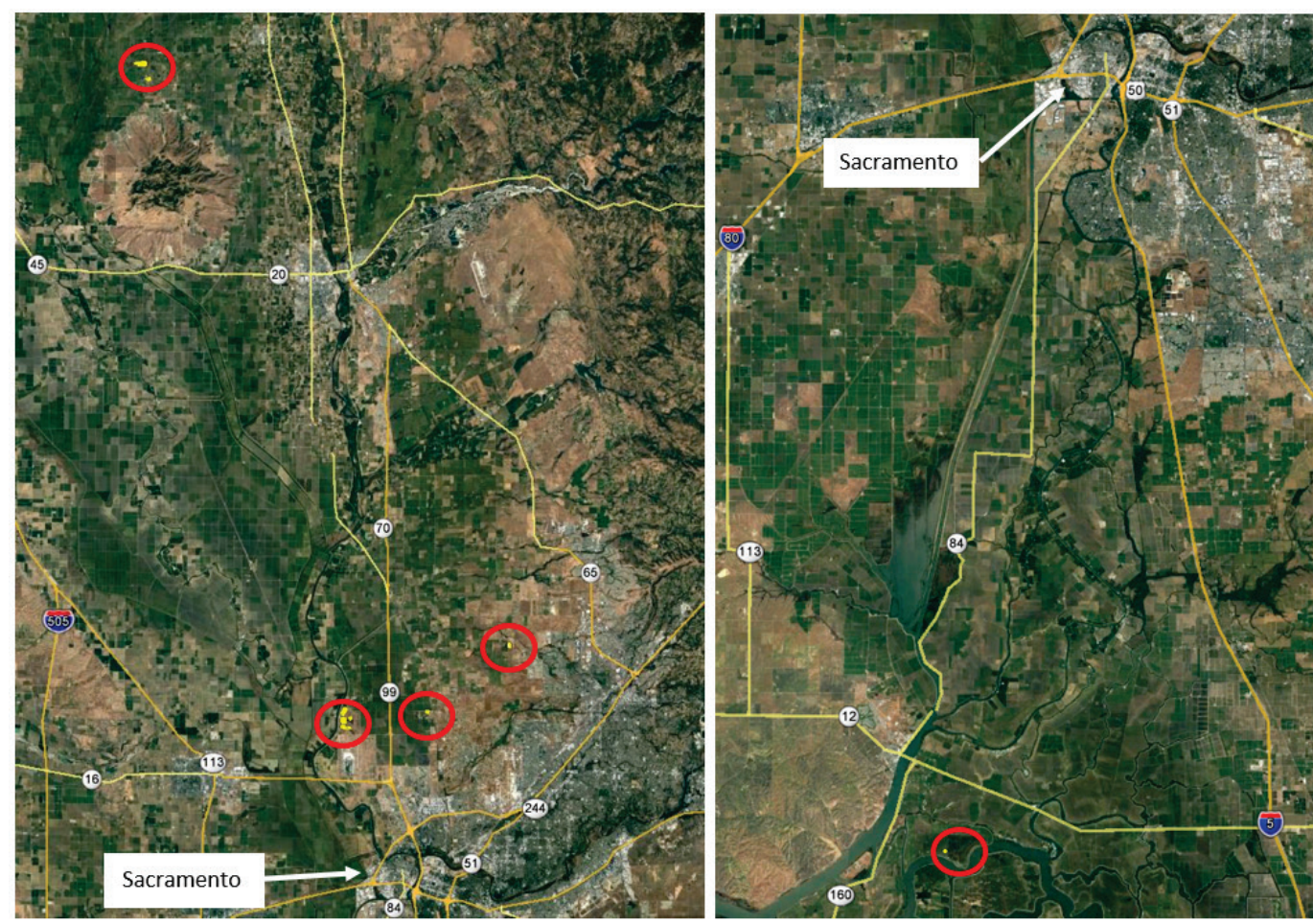

Site selection criteria included formerly irrigated croplands no longer receiving supplemental water additions. Potential study areas also displayed potential wetland conditions based on the presence of hydric soils and evidence of potential hydrophytic vegetation (e.g., remnant plant remains) although hydrophytic vegetation was not dominant at all study locations during initial site visits. Additionally, remote sensing and aerial imagery resources were evaluated to determine if study areas displayed potential wetness signatures (Berkowitz et al. 2016; USDA NRCS 1997). 
Finally, limited site access was required to protect monitoring equipment from vandalism. A subset of these sites (Table 1) were identified for further analysis and monitoring. Installation of monitoring equipment occurred at 13 study locations, representing a geographically and morphologically diverse set of study areas located on a combination of properties managed by a variety of city, county, federal, state, and non-profit entities.

Table 1. Study area location, size, irrigation cessation year, and cropping history.

\begin{tabular}{|c|l|c|l|l|}
\hline Study location & County & Size (acres) & Last irrigation & Crop history \\
\hline A1 & Sacramento & 4 & June 2005 & Wheat \\
\hline A2 & Sacramento & 15.3 & July 2000 & Safflower/wheat \\
\hline A3 & Sacramento & 5.26 & August 2005 & Rice \\
\hline A4, A6 & Sacramento, Sutter & 31.4 & August 2005 & Rice \\
\hline A5 & Sacramento & 32 & August 2005 & Wheat \\
\hline G8-1 & Butte, Plumas & 20.7 & August 2015 & Pasture/Rice \\
\hline G8-2 & Butte, Plumas & 15.5 & August 2015 & Pasture/Rice \\
\hline G9 & Butte, Plumas & 18.1 & August 2015 & Pasture/Rice \\
\hline G27 & Butte, Plumas & 8.19 & August 2015 & Pasture/Rice \\
\hline N1 & Sacramento, Sutter & 7.52 & August 1999 & Wheat/Pasture \\
\hline R1 & Placer & 12.8 & August 2015 & Wheat/Pasture \\
\hline T1 & Sacramento & 1.1 & August 2015 & Rice \\
\hline
\end{tabular}

tSample locations A4 and A6 are co-located on separate portions of the same large fallow field.

\subsection{Water table monitoring}

Once study areas were selected, analysis of potential wetness signatures on aerial imagery was utilized to determine where installation of monitoring equipment should occur. It is important to note that monitoring locations were not selected randomly or systematically stratified across the landscape, but were targeted in areas displaying potential wetness signatures on aerial images, remnant hydrophytic vegetation species, lower elevation areas identified via LiDAR, and/or other evidence that wetland conditions may be present. In study areas exhibiting an apparent wetland boundary, monitoring equipment was installed near the estimated boundary location. This approach allowed for a determination of both 1) the presence/absence of wetland conditions and 2) the spatial extent of wetlands within each study location.

Triplicate shallow groundwater monitoring wells were installed to 20 inches below the soil surface as described in USACE (2005; Figure 2). 
Slotted PVC well screens were surrounded with a sand filter pack to remove fine particles and provide a zone of high hydraulic conductivity that promotes water movement toward the well. Each monitoring well was mounded with clay and sloped away from the well inlet to avoid infiltration of surface water into the bore hole (Figure 2). One pressure transducer (In-Situ LevelTroll ${ }^{\circledR} 500$ ) with automated data logging capabilities was installed at each well location. Barometric pressure was accounted for via vented cables. Water levels were recorded twice daily. Water table measurements began between October and December 2015, and continued until June 2016 capturing the normal wet portion of the growing season within the region (October - May; USDA-NRCS 2006). One data logger malfunctioned during the monitoring period and was excluded from analysis.

Figure 2. Schematic of monitoring well installation (left; USACE 2005) and deployment of automated data logger during fall 2015 (right).
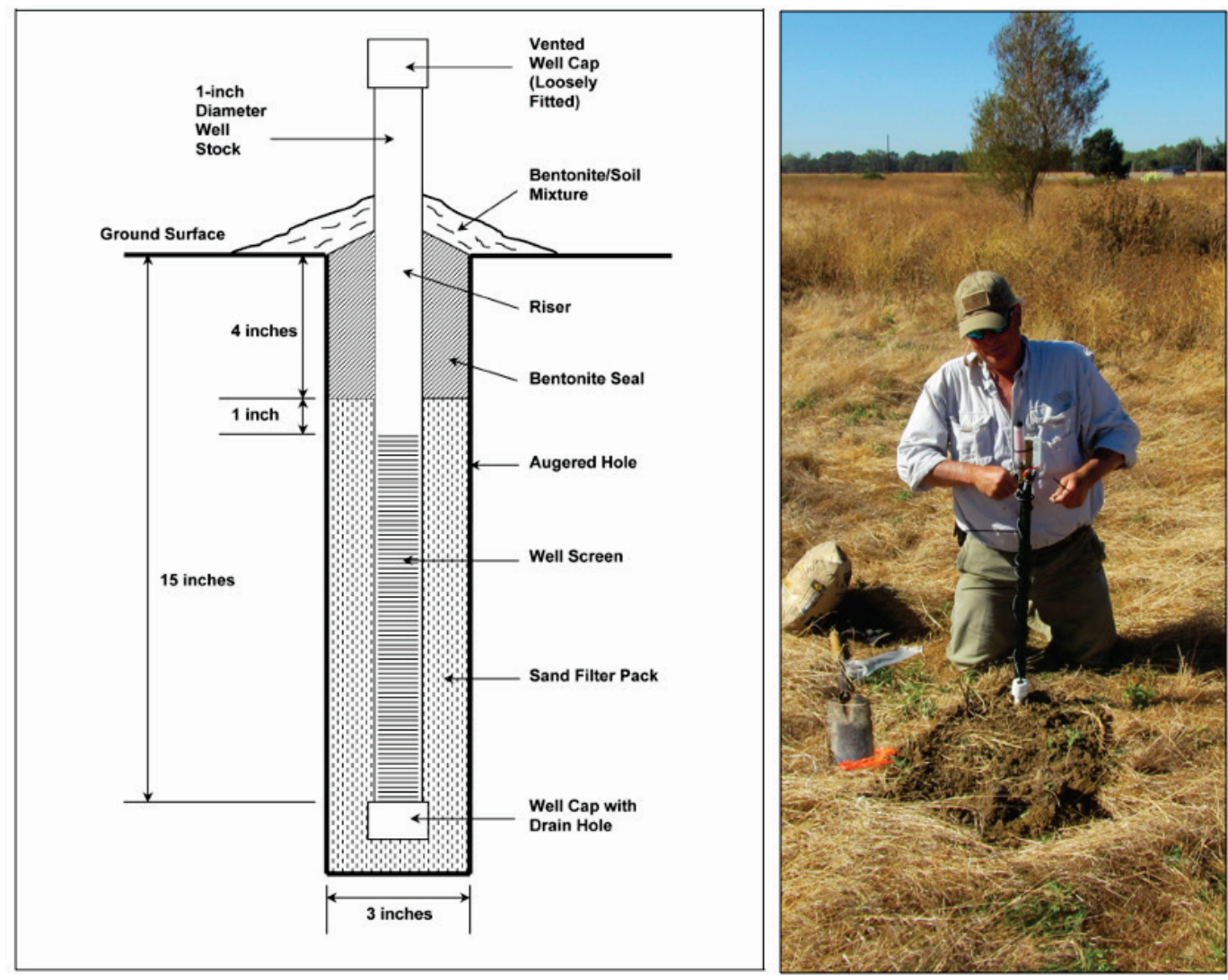

\subsection{Analysis of rainfall normality}

Analysis of rainfall normality is an essential tool for determining when wetland hydrology can be expected to occur, with regard to both on-site 
and off-site data analysis and interpretation (Sprecher and Warne 2000). On-site rainfall data was collected using tipping bucket rain gauges (Onset HOBO ${ }^{\circledR}$ Rain Gauge Data Logger). Precipitation data was evaluated through the application of the Direct Antecedent Rainfall Evaluation Method (DAREM) (Sumner et al. 2009). The DAREM method examines rainfall patterns during the previous three months to determine if precipitation during each month of the monitoring period was normal, above normal, or below normal compared to the $30^{\text {th }}$ and $70^{\text {th }}$ percentile averages based on long-term (i.e., 30-year) average precipitation records provided in WETS tables developed by the USDA-NRCS National Water and Climate Center (Sprecher and Warne 2000; Berkowitz and Noble 2015). The DAREM analysis approach has been utilized in a number of studies examining wetland factors, including hydrology and hydric soil determinations and is recommended for interpreting wetland hydrologic data for USACE wetland delineation and monitoring efforts (USACE 2005; Berkowitz et al. 2014) as well as the Hydric Soils Technical Standard (HSTS) (National Technical Committee for Hydric Soils (NTCHS) 2015).

\subsection{Aerial image interpretation}

At each study location, available aerial images were examined and analyzed for potential wetland hydrologic features. Images collected during wetter than normal rainfall periods were excluded from analysis as described in Berkowitz et al. (2016). The most commonly observed indicators of potential wetland hydrology identified included: areas consistently excluded from cropping, surface water/saturation, shifts in vegetation, areas of crop stress, and other features. Potential wetness signatures were compared with nearby agricultural and mapped wetland locations to aid in verification and analysis of results.

Potential wetland features were outlined using polygon tools in order to estimate the spatial extent of the feature and track features from year to year. While not all discolorations provide evidence of a vegetation shift, soil saturation, or other potential wetland signatures, it is possible to find consistent signature patterns on the landscape by comparing multiple images collected over time. Composite images were developed by combining wetness signatures from multiple images (Appendix B). Berkowitz et al. (2016) provides an in-depth discussion of image interpretation specific to identifying potential wetland hydrology signatures in irrigated areas, development of composite images, and data interpretation. 


\section{Results and Discussion}

\subsection{Water table measurements}

Following the conclusion of data collection, each study location was evaluated to identify continuous high water table periods (hydroperiods) during which water remained within 12 inches of the soil surface (Table 2; Figure 3). The observed hydroperiods ranged from 9 to 37 days. Mean hydroperiod was 20.8 days, with a standard error of 2.0 days. Appendix B contains data collected by each monitoring well. All 13 study locations exhibited high water tables during March. Additionally, six of the thirteen study locations exhibited multiple periods of high water table, occurring in December/January or January/February. The patterns of soil saturation observed in the current study agree with Rains et al. (2006) who investigated ephemeral wetland hydrology in the region, reporting that early wet-season rainfall events infiltrate the soil augmenting soil moisture. As additional rainfall occurs, soil moisture increases toward the soil surface, resulting in the near surface water tables (Figure 4).

Table 2. Results of ground water monitoring conducted in formerly irrigated areas.

\begin{tabular}{|c|c|c|l|l|c|}
\hline Site & $\begin{array}{c}\text { Consecutive high } \\
\text { water table days }\end{array}$ & $\begin{array}{c}\text { Wells with } \geq 14 \\
\text { days }\end{array}$ & \multicolumn{1}{|c|}{ Dates } & \multicolumn{1}{|c|}{$\begin{array}{c}\text { Rainfall } \\
\text { Normality }\end{array}$} & Meets TSWTM \\
\hline A1 & 14 & $3 / 3$ & $3 / 6 / 16-3 / 19 / 16$ & Dry & Yes \\
\hline A2 & 9 & $0 / 3$ & $3 / 11 / 16-3 / 20 / 16$ & Dry & No \\
\hline A3 & 17 & $3 / 3$ & $3 / 6 / 16-3 / 22 / 16$ & Dry & Yes \\
\hline A4 & 29 & $3 / 3$ & $3 / 6 / 16-4 / 03 / 16$ & Dry/Normal & Yes \\
\hline A5 & 15 & $3 / 3$ & $12 / 26 / 16-1 / 10 / 16$ & Normal/Dry & Yes \\
\hline & 20 & $3 / 3$ & $3 / 6 / 16-3 / 25 / 16$ & Dry & Yes \\
\hline A6 & 18 & $3 / 3$ & $3 / 11 / 16-3 / 28 / 16$ & Dry & Yes \\
\hline G8-1 & 37 & $2 / 2^{\ddagger}$ & $1 / 21 / 16-2 / 27 / 16$ & Dry/Wet & No** \\
\hline & 22 & $2 / 2^{\ddagger}$ & $3 / 5 / 16-3 / 27 / 16$ & Normal & Yes \\
\hline G8-2 & 34 & $3 / 3$ & $1 / 22 / 16-2 / 24 / 16$ & Normal/Wet & No $^{* *}$ \\
\hline & 24 & $2 / 3$ & $3 / 5 / 16-3 / 29 / 16$ & Normal & Yes \\
\hline G9 & 22 & $3 / 3$ & $1 / 22 / 16-2 / 12 / 16$ & Normal/Wet & No** $^{*}$ \\
\hline & 22 & $3 / 3$ & $3 / 5 / 16-3 / 27 / 16$ & Normal & Yes $^{*}$ \\
\hline G27 & 16 & $1 / 3$ & $1 / 22 / 16-2 / 6 / 16$ & Normal/Wet & No** $^{*}$ \\
\hline & 15 & $1 / 3$ & $3 / 5 / 16-3 / 16 / 16$ & Normal & Yes $^{*}$ \\
\hline N1 & 17 & $3 / 3$ & $1 / 18 / 16-2 / 3 / 16$ & Dry/Normal & Yes \\
\hline & 16 & $3 / 3$ & $3 / 5 / 16-3 / 20 / 16$ & Dry & Yes $^{*}$ \\
\hline
\end{tabular}




\begin{tabular}{|c|c|c|l|l|c|}
\hline Site & $\begin{array}{c}\text { Consecutive high } \\
\text { water table days }\end{array}$ & $\begin{array}{c}\text { Wells with } \geq 14 \\
\text { days }\end{array}$ & \multicolumn{1}{|c|}{ Dates } & \multicolumn{1}{|c|}{$\begin{array}{c}\text { Rainfall } \\
\text { Normality }{ }^{\dagger}\end{array}$} & Meets TSWTM \\
\hline R1 & 20 & $3 / 3$ & $3 / 6 / 16-3 / 25 / 16$ & Dry & Yes \\
\hline T1 & 33 & $3 / 3$ & $1 / 1 / 16-2 / 7 / 16$ & Dry/Normal & Yes \\
\hline & 16 & $3 / 3$ & $3 / 5 / 16-3 / 20 / 16$ & Normal & Yes \\
\hline
\end{tabular}

†Two rainfall normality values are provided when high water table periods occurred in more than one month. ${ }^{\ddagger}$ Monitoring well malfunction reduced sample size at G8-1. *Sample location A5 was influenced by water in an irrigation ditch adjacent to the site during October, as a result the water tables cannot be solely attributed to local hydrologic events. **TSWTM not considered met due to wetter than normal rainfall conditions during a portion of the high water table period.

Figure 3. Example ground water and rainfall monitoring data at T1. Note the response of groundwater levels to rainfall events. Dashed line represents 12 inches below ground surface (BGS).

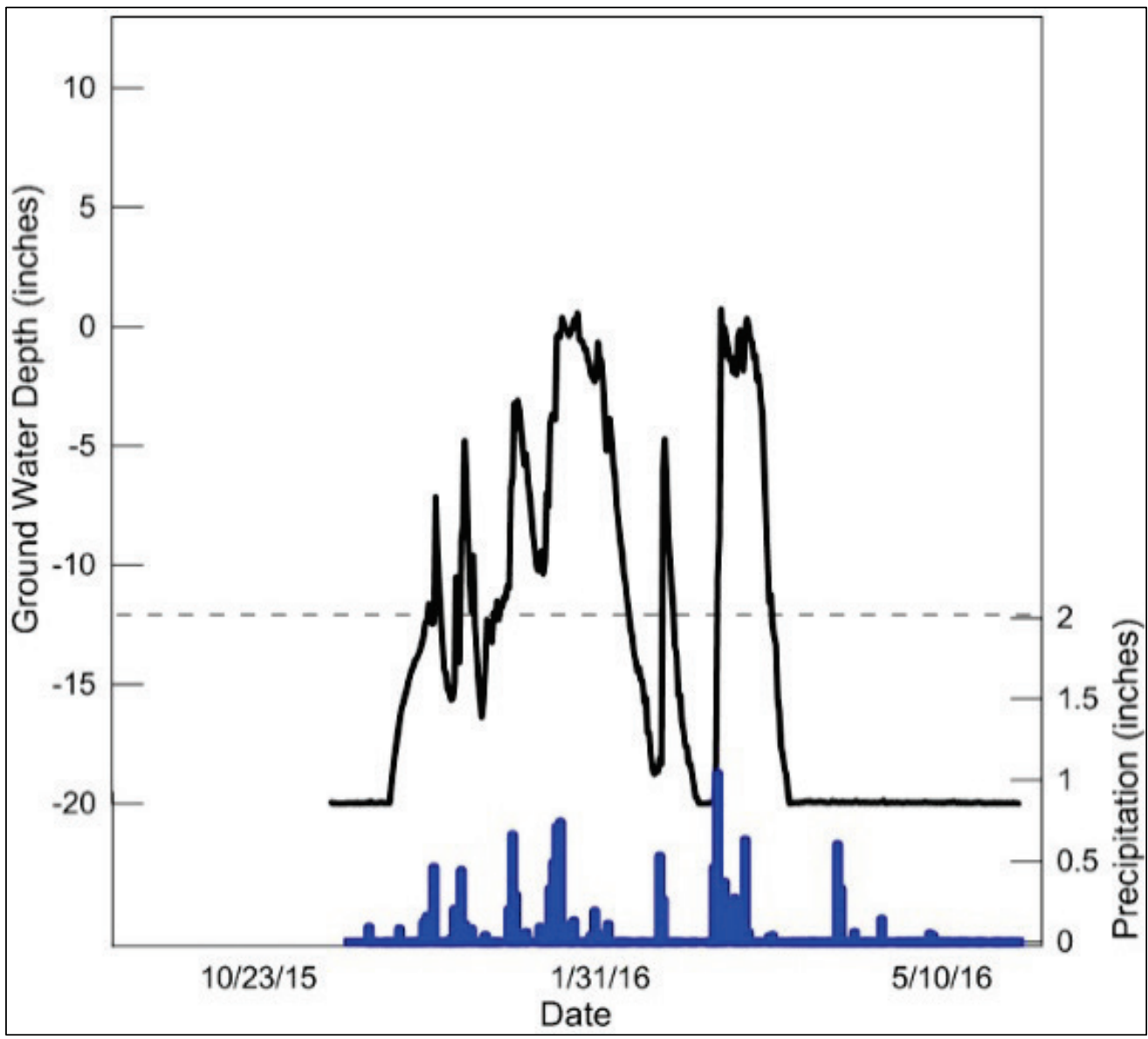

Monitoring wells at study location A5 displayed several high water table events potentially enhanced by the presence of an irrigation ditch adjacent to the site (Figure 5). As a result, water table data during periods when the ditch was full cannot be attributed solely to precipitation events. Data collected during periods when the ditch contained water were not included in the analysis. Wetland hydrology was identified at the site during a 
20 day period in March when water tables responded to a series of rain events and the irrigation ditch remained empty for over 30 days prior to the high water table period. The 20 day hydroperiod was similar to durations observed at other study locations in the area, suggesting that the March event can be attributed to precipitation. Many areas throughout the Arid West region contain ditches and other features designed to convey irrigation water, and the proximity of ditches to study locations, as well as periods when ditches are being utilized, should be considered when evaluating potential wetland areas.

Figure 4. Groundwater and precipitation patterns at study location A4. Note that early season rainfall events increase soil moisture and shallow groundwater elevation prior to the onset of wetland hydrologic conditions in which water tables reach the upper portion of the soil profile. Dashed line represents 12 inches (BGS).

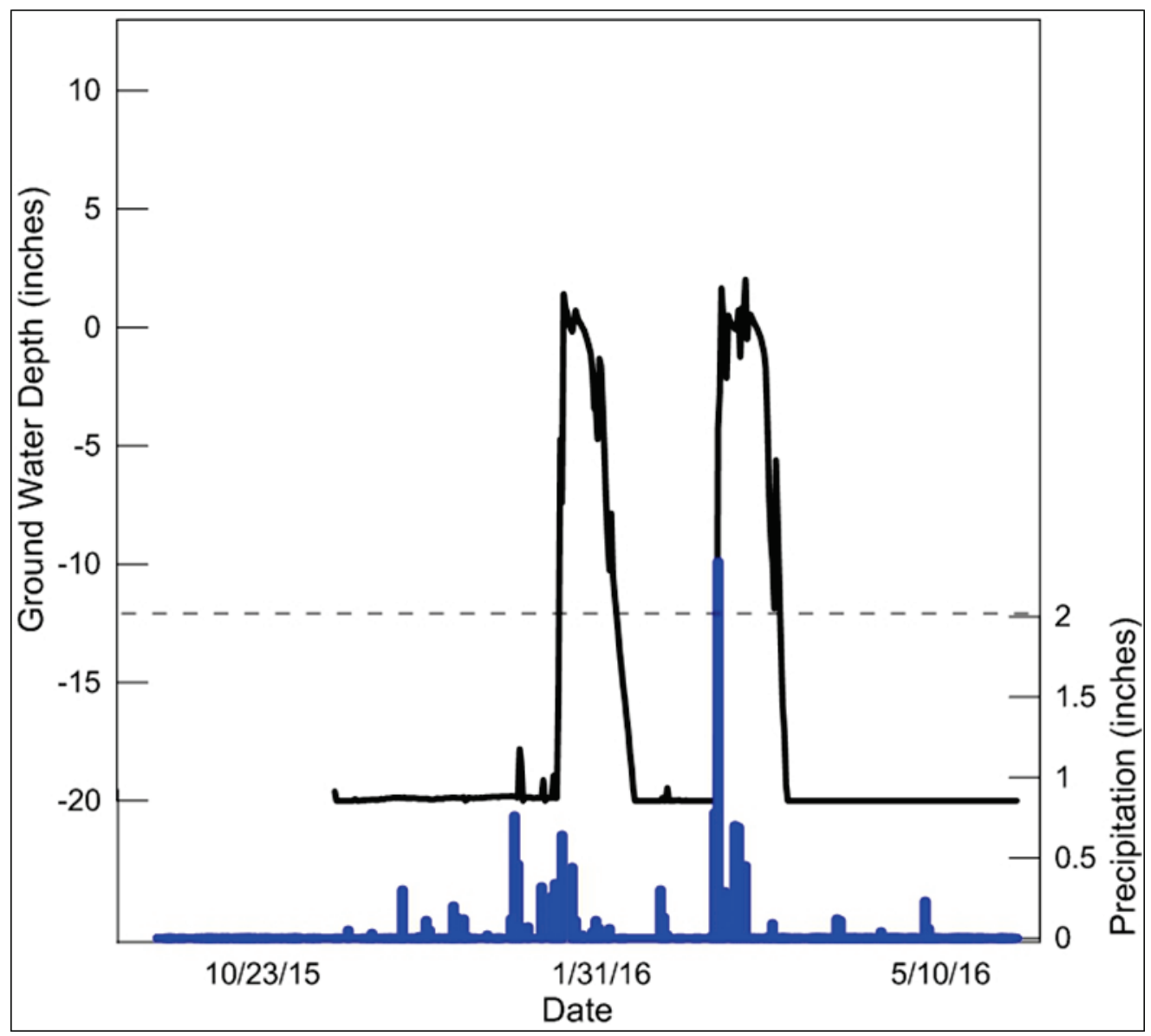


Figure 5. Water table monitoring data at study location A5, which was adjacent to an irrigation ditch. Asterisks indicate high water table events associated with periods when water was observed in the irrigation ditch. Precipitation driven high water tables occurred during March, an extended period when no water was present in the irrigation ditch. Dashed line represents 12 inches (BGS).

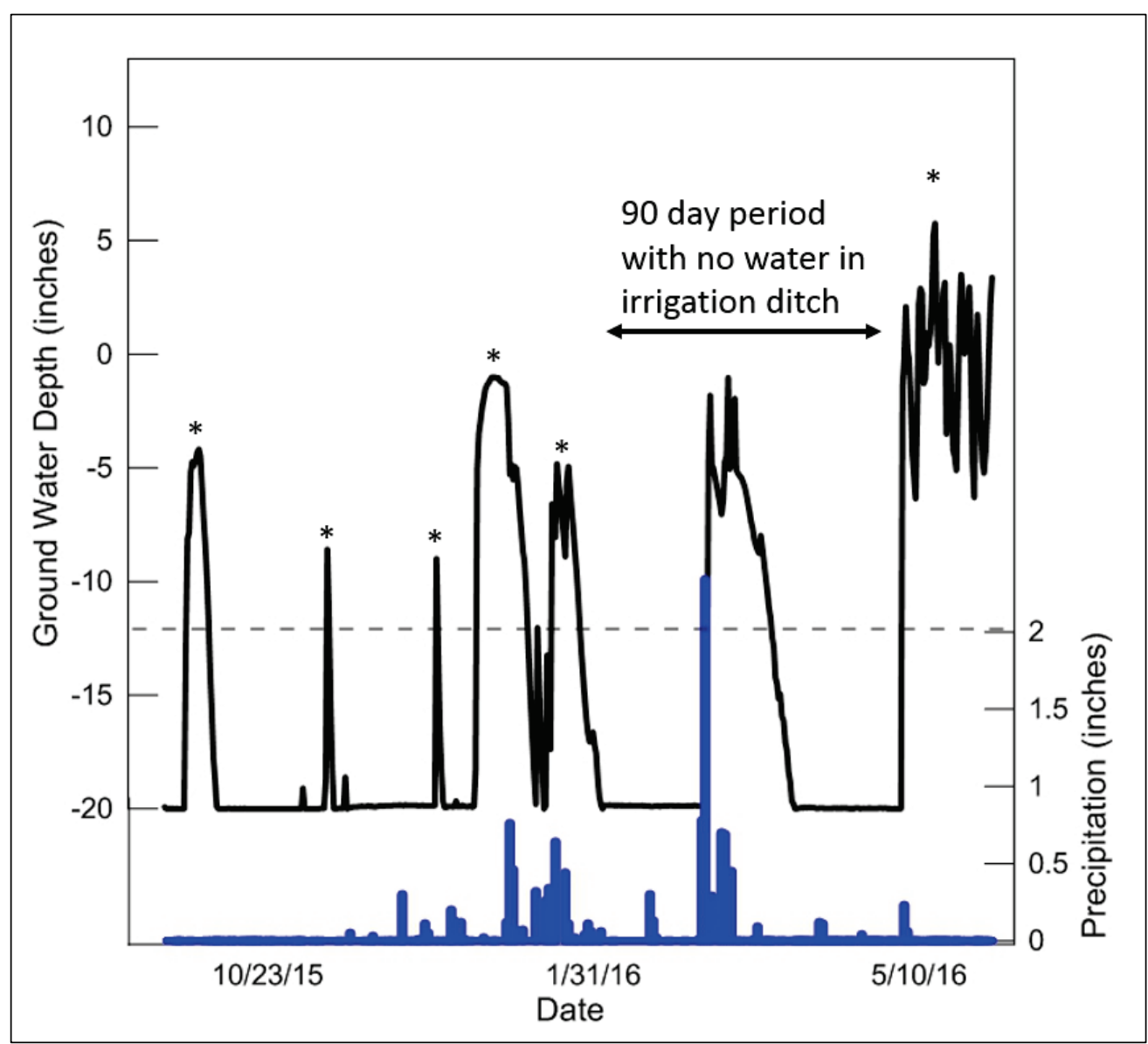

The short duration hydroperiods identified are within the range observed in regional wetlands (Silveira 1998), but remain shorter than inundation periods reported by Pyke and Matry (2005) and others who examined unaltered wetlands with ephemeral hydrology in the Central Valley of California. As noted in USACE (2012; 2008), activities associated with agriculture and other land management practices can alter natural patterns of wetland hydrology resulting in hydroperiods that are longer or shorter than observed in unaltered locations. As a result, studies examining the duration and frequency of high water table events in unaltered wetlands may not be directly applicable to evaluations conducted in altered landscapes. 
Monitoring well data indicates that, at the sample locations examined, soils have the capacity to support high water tables in the absence of irrigation inputs. Soil type plays a large role in maintaining high water tables within the study area, which are often characterized by the presence of duripans, clay layers, and indurated horizon with low rates of leaching (i.e., claypans) (Soil Survey Staff 2016). For example, soils underlying several study locations have a mapped restrictive layer 20-40 inches below the soil surface (Table 3). Clay layers and restrictive layers capable of perching shallow groundwater near the soil surface were identified during monitoring equipment installation. Further, many of the monitoring locations have layers exhibiting low saturated hydrologic conductivity (kSat) including values ranging from 0.00 to 0.20 inches per hour (Nikiforoff 1941; Hanes and Stromberg 1998). Study location T1, which lacks a restrictive layer, is characterized by poorly drained mucky silt loam and thick organic soil horizons characteristic of marsh landforms; which remain wet due to landscape position and endosaturation associated with the Sacramento-San Juaquin River Delta (Fujii 1998). 
Table 3. Mapped soil series information for each sample location (Soil Survey Staff 2016).

\begin{tabular}{|c|c|c|c|c|c|c|c|}
\hline Location & $\begin{array}{l}\text { Dominant soil series } \\
\text { (mapped) }\end{array}$ & Typical Profile (in) & $\begin{array}{l}\text { Drainage } \\
\text { Class }^{\dagger}\end{array}$ & \begin{tabular}{|l|} 
Restrictive \\
Layer (in)
\end{tabular} & Ksat $^{\ddagger}$ (in/hr) & $\begin{array}{l}\text { Hydric } \\
\text { Soil }\end{array}$ & $\begin{array}{l}\text { Hydric } \\
\text { Rating }\end{array}$ \\
\hline $\mathrm{A} 1, \mathrm{~A} 2$ & $\begin{array}{l}\text { Cosumnes silt loam, } \\
\text { partially drained, } 0 \text { - } 2 \\
\text { percent slopes }\end{array}$ & $\begin{array}{l}0 \text { - 8: silt loam, } 8 \text { - 21: } \\
\text { stratified silty clay loam - clay, } \\
21 \text { - 43: stratified clay loam - } \\
\text { clay, } 43 \text { - } 60: \text { stratified clay } \\
\text { loam - clay }\end{array}$ & SPD & $>80$ & 0.06 to 0.20 & Yes & 99 \\
\hline A3, A5 & $\begin{array}{l}\text { Clear Lake clay, hardpan } \\
\text { substratum, drained, } 0 \text { - } \\
1 \text { percent slopes }\end{array}$ & $\begin{array}{l}0 \text { - 15: clay, } 15 \text { - 34: clay, } 34 \text { - } \\
\text { 48: clay loam, } 48 \text { - 64: } \\
\text { cemented }\end{array}$ & SPD & 48 to 64 & 0.00 to 0.00 & Yes & 93 \\
\hline A4, A6 & $\begin{array}{l}\text { Valpac loam, partially } \\
\text { drained, } 0 \text { - } 2 \text { percent } \\
\text { slopes }\end{array}$ & $\begin{array}{l}0 \text { - 10: loam, } 10-61 \text { : } \\
\text { stratified sandy loam - silty } \\
\text { clay loam }\end{array}$ & SPD & $>80$ & 0.20 to 0.57 & Yes & 100 \\
\hline A5 & $\begin{array}{l}\text { San Joaquin-Galt } \\
\text { complex, leveled, } 0 \text { - } 1 \\
\text { percent slopes }\end{array}$ & $\begin{array}{l}\text { 0 - 15: silt loam, } 15 \text { - 20: clay } \\
\text { loam, } 20 \text { - 46: indurated, } 46 \text { - } \\
60: \text { stratified sandy loam - } \\
\text { loam }\end{array}$ & MWD & 20 to 46 & 0.00 to 0.00 & No & 44 \\
\hline $\begin{array}{l}\text { G8-1, } \\
\text { G8-2 }\end{array}$ & $\begin{array}{l}\text { Subaco taxadjunct clay, } \\
0 \text { - } 1 \text { percent slopes }\end{array}$ & $\begin{array}{l}\text { 0 - 8: clay, } 8 \text { - 16: silty clay, } 16 \\
\text { - 29: silty clay, } 29 \text { - 35: clay, } \\
35 \text { - 42: cemented silty clay } \\
\text { loam, } 42 \text { - } 60 \text { : sandy loam, } \\
\text { material }\end{array}$ & PD & 20 to 40 & 0.00 to 0.00 & Yes & 98 \\
\hline G9 & $\begin{array}{l}\text { Esquon-Neerdobe , } 0 \text { - } 1 \\
\text { percent slopes }\end{array}$ & $\begin{array}{l}0 \text { - 5: clay, } 5 \text { - 11: clay, } 11 \text { - } \\
\text { 22: clay, } 22 \text { - 35: clay, } 35 \text { - 46: } \\
\text { clay, } 46 \text { - } 50: \text { silty clay, } 50 \text { - } \\
\text { 56: silty clay, } 56 \text { - } 67: \\
\text { cemented material }\end{array}$ & PD & 40 to 60 & 0.00 to 0.00 & Yes & 98 \\
\hline G27 & $\begin{array}{l}\text { Gridley taxadjunct-Calcic } \\
\text { Haploxerolls } 0 \text { - } 2 \\
\text { percent slopes }\end{array}$ & $\begin{array}{l}0 \text { - 10: loam, } 10 \text { - 20: clay } \\
\text { loam, } 20 \text { - 22: clay, } 22 \text { - } 60 \text { : } \\
\text { cemented material }\end{array}$ & SPD & 20 to 40 & 0.00 to 0.00 & No & 5 \\
\hline \multirow[t]{2}{*}{ N1 } & $\begin{array}{l}\text { San Joaquin sandy } \\
\text { loam, } 0-2 \text { percent } \\
\text { slopes }\end{array}$ & $\begin{array}{l}\text { 0 - 16: sandy loam; } 16 \text { - 20: } \\
\text { clay } \\
20 \text { - 40: indurated } \\
40 \text { - } 60 \text { : stratified sandy loam } \\
\text { - loam }\end{array}$ & WD & 20 to 40 & 0.00 to 0.06 & No & 0 \\
\hline & $\begin{array}{l}\text { San Joaquin silt loam, } 0 \\
-3 \text { percent slopes }\end{array}$ & $\begin{array}{l}0 \text { - 23: silt loam, } 23 \text { - 28: clay } \\
\text { loam, } 28 \text { - } 54: \text { indurated, } 54 \text { - } \\
60: \text { stratified sandy loam - } \\
\text { loam }\end{array}$ & MWD & 28 to 54 & 0.00 to 0.00 & No & 4 \\
\hline R1 & $\begin{array}{l}\text { Cometa-Fiddyment } \\
\text { complex, } 1 \text { - } 5 \text { percent } \\
\text { slopes }\end{array}$ & $\begin{array}{l}0 \text { - 18: sandy loam, } 18 \text { - } 29 \text { : } \\
\text { clay, } 29 \text { - } 60 \text { : sandy loam }\end{array}$ & WD & $>80$ & 0.00 to 0.06 & No & 5 \\
\hline T1 & $\begin{array}{l}\text { Rindge mucky silt loam, } \\
\text { partially drained, } 0 \text { - } 2 \\
\text { percent slopes }\end{array}$ & $\begin{array}{l}0 \text { - 13: mucky silt loam, } 13 \text { - } \\
60 \text { : mucky peat }\end{array}$ & VPD & $>80$ & 1.98 to 5.95 & Yes & 100 \\
\hline
\end{tabular}

† WD = well drained; MWD = moderately well drained; SPD = somewhat poorly drained; PD = poorly drained; VPD = very poorly drained. tKsat = saturated hydraulic conductivity of the limiting layer; in = inches; in/hr = inches per hour. 


\subsection{Rainfall normality}

Precipitation amounts varied based upon monitoring period and location (Table 4). The DAREM analysis indicated that rainfall was dominated by normal or drier than normal conditions throughout the monitoring period (Table 5; Appendix C), although study location $\mathrm{G}$ exhibited wetter than normal rainfall during the month of February 2016. Precipitation during the observation period followed typical patterns in the region in which a cool, rainy period occurs from November through April, followed by an extended dry period from May through October (USDA NRCS 2006).

Based on data from Hanes and Stromberg (1998), Sacramento, CA has mean annual precipitation of 18.1 inches and mean annual potential evapotranspiration is estimated to be 51.9 inches (University of California 1987). Examining monthly precipitation and potential evapotranspiration relationships, precipitation exceeds potential evapotranspiration for the period of November through February (WebWIMP 2003; Figure 6). During this period there is a 6.6 inch surplus of water available for soil moisture recharge, percolation to groundwater, or runoff (Hanes and Stromberg 1998). The presence of excess water during the winter and early spring months represents a potential source of hydrology to the formerly irrigated wetlands examined in the current study.

Table 4. Rainfall data collected during the study period.

\begin{tabular}{|c|c|c|}
\hline Study location & Rainfall (inches) & Monitoring period \\
\hline A & 12.2 & $9 / 22 / 15-06 / 01 / 16$ \\
\hline$G$ & 5.2 & $1 / 21 / 16-06 / 01 / 16$ \\
\hline N & 7.48 & $2 / 19 / 15-06 / 01 / 16$ \\
\hline$R$ & 15.5 & $11 / 19 / 15-06 / 01 / 16$ \\
\hline$T$ & 10.5 & $11 / 18 / 15-05 / 29-16$ \\
\hline
\end{tabular}

Table 5. Monthly DAREM analysis results during the monitoring period.

\begin{tabular}{|c|c|c|c|c|c|}
\hline \multirow{2}{*}{ Month } & \multicolumn{5}{|c|}{ Site } \\
\cline { 2 - 6 } & A & G & N & R & T \\
\hline October & Normal & & & & \\
\hline November & Dry & & & & Dry \\
\hline December & Normal & Normal & Normal & Dry & Dry \\
\hline January & Dry & Normal & Dry & Dry & Normal \\
\hline February & Normal & Wet & Normal & Normal & Dry \\
\hline March & Dry & Normal & Dry & Dry & Normal \\
\hline April & Normal & Normal & Normal & Normal & Normal \\
\hline May & Normal & Dry & Normal & Normal & Normal \\
\hline
\end{tabular}


Figure 6. Water budget for Sacramento, CA (WebWIMP 2003).

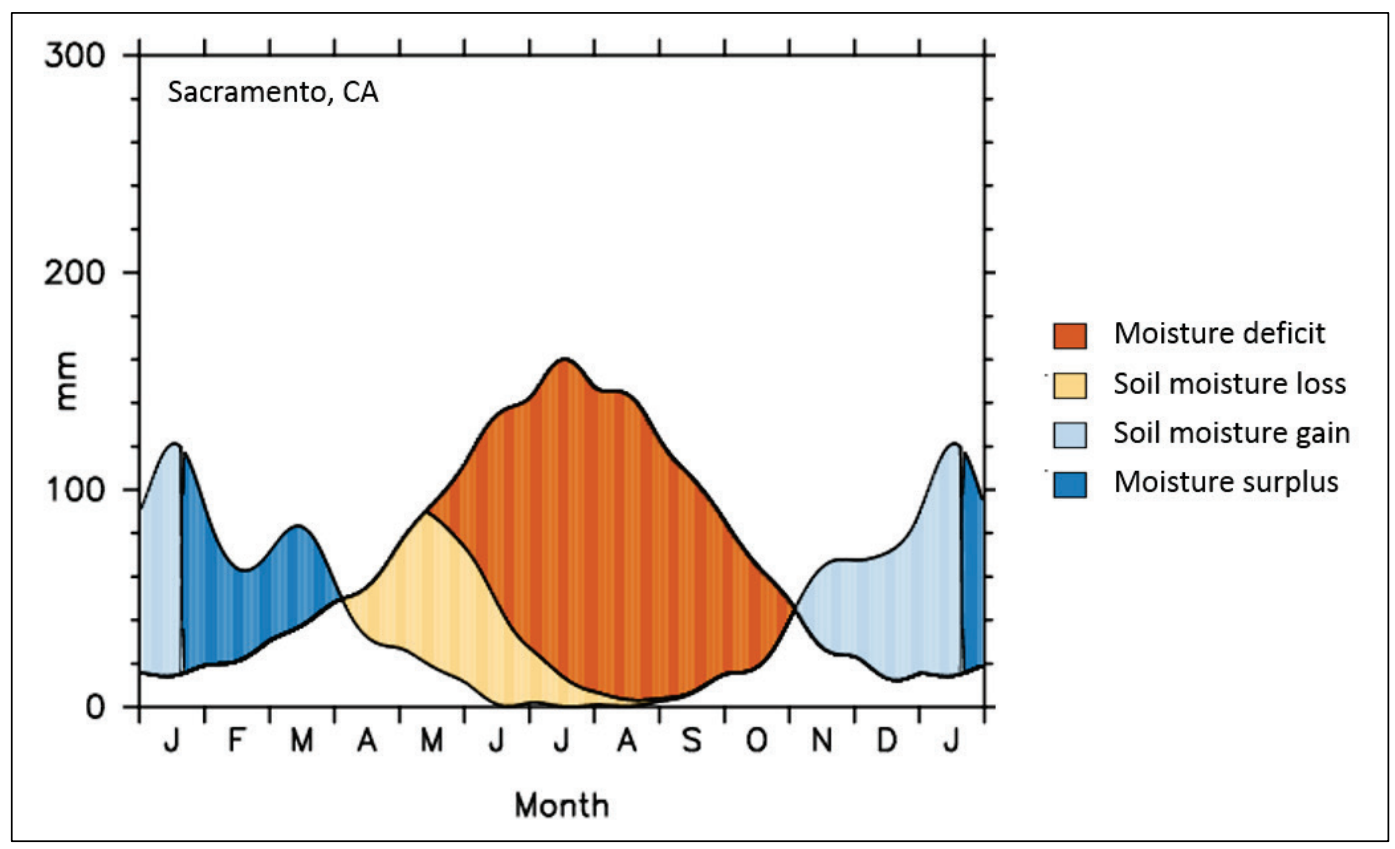

The Central Valley of California experienced protracted drought conditions from 2012 to 2016 (Williams et al. 2015; Wang et al. 2016). Drought conditions lasting 2 or more consecutive years can impact wetland hydrology (USACE 2008). The Palmer Drought Severity Index (PDSI) is used to track drought conditions over time, incorporating rainfall normality and temperature to estimate evapotranspiration and soil moisture (Sprecher and Warne 2000; Figure 7). Based upon PDSI data, moderate to severe drought conditions dominated the 24 months leading up to the monitoring period, and drought conditions continued into the first three months of the study (Table 6). As a result, soil moisture levels and water tables in the formerly irrigated study locations likely remained below historic levels at the beginning of the study (Wang et al. 2016). The PDSI ratings shifted into Moderate drought or Mid-range conditions during the study. It is important to note that both rainfall normality and PDSI results were not indicative of a wetter than normal period or moist soil conditions capable of producing erroneous water table monitoring results. 
Figure 7. Palmer drought severity index during October 2015 , the first month of water table monitoring.

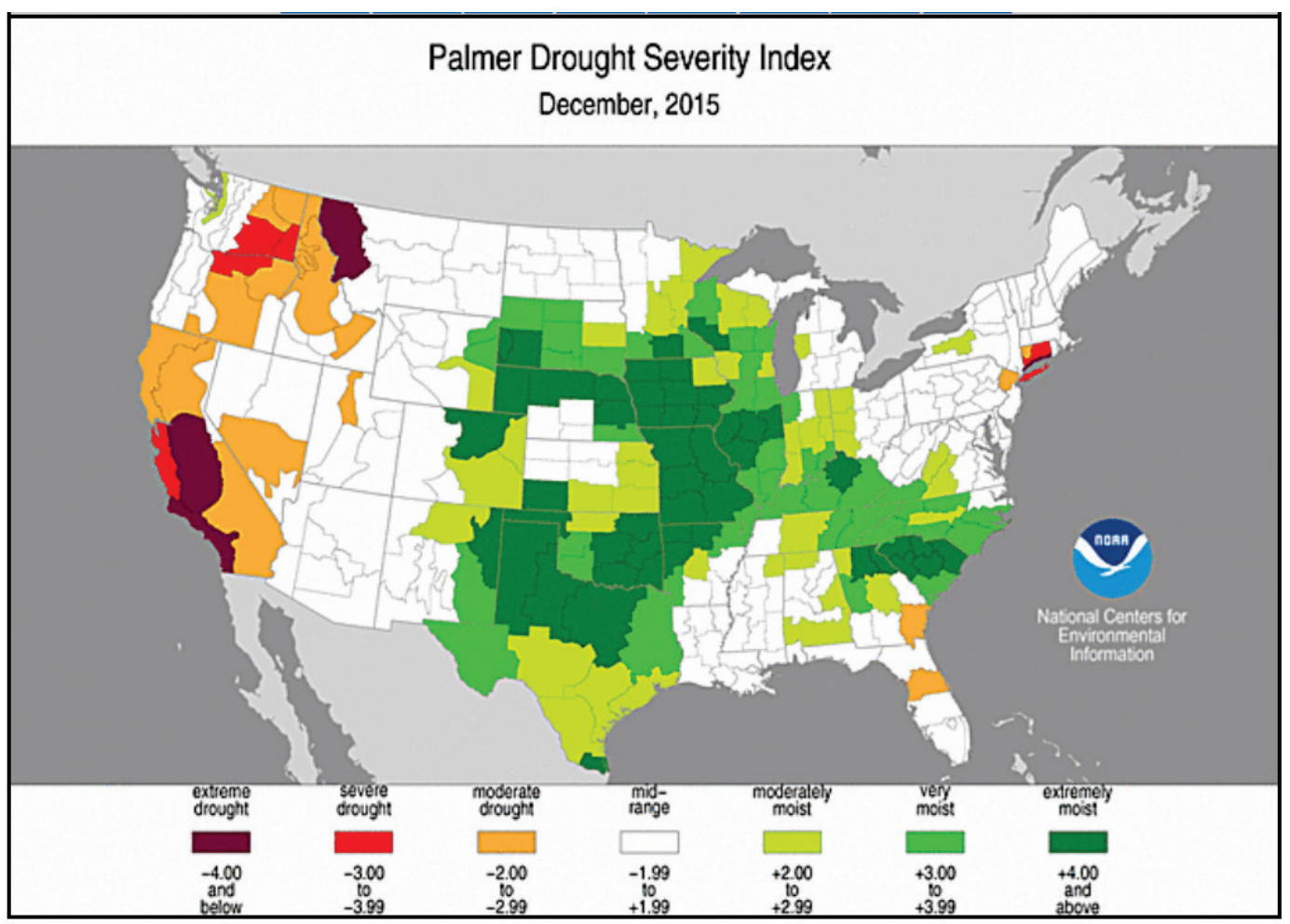

Table 6. Palmer Drought Severity Index ratings 2013-2016. Monitoring period data in italics.

\begin{tabular}{|c|c|c|c|c|}
\hline \multirow[b]{2}{*}{ Month } & \multicolumn{4}{|c|}{ Year } \\
\hline & 2013 & 2014 & 2015 & 2016 \\
\hline January & Mid-range & Extreme drought & Moderate drought & Mid-range \\
\hline February & Mid-range & Severe drought & Moderate drought & Moderate drought \\
\hline March & Moderate drought & Moderate drought & Severe drought & Mid-range \\
\hline April & Moderate drought & Moderate drought & Severe drought & Mid-range \\
\hline May & Moderate drought & Moderate drought & Severe drought & Mid-range \\
\hline June & Moderate drought & Severe drought & Severe drought & Mid-range \\
\hline July & Moderate drought & Severe drought & Severe drought & \\
\hline August & Moderate drought & Severe drought & Severe drought & \\
\hline September & Mid-range & Moderate drought & Severe drought & \\
\hline October & Moderate drought & Moderate drought & Severe drought & \\
\hline November & Moderate drought & Moderate drought & Severe drought & \\
\hline December & Severe drought & Mid-range & Moderate drought & \\
\hline
\end{tabular}




\subsection{Application of the Technical Standard for Water-Table Monitoring of Potential Wetland Sites (TSWTM)}

The soil saturation criteria of the TSWTM requires a water table within 12 inches of the soil surface for 14 consecutive days during the growing season. Rainfall normality must also be considered when applying the TSWTM, which requires a hydrologic return interval of 5 years in 10 (50\% probability). When less than 10 years of hydrology monitoring data is available, USACE (2005) recommends examination of a three month period prior to high water events to determine if precipitation was wetter than normal, normal, or drier than normal (i.e., DAREM analysis). As a result, the current study utilized a combination of 1 ) high water table events in one or more of the monitoring wells at each site and 2) events occurring during normal or drier than normal rainfall conditions to determine if study locations satisfied the TSWTM criteria. Twelve of the study areas met the TSWTM during the monitoring period (Table 2). Two locations met the TSWTM multiple times. Sample location near area G, met the saturation depth and duration requirement during January/February, but failed to meet the TSWTM due to wetter than normal rainfall conditions occurring during the month of February. All sample locations at area G met TSWTM criteria during March.

One study area, (A2) failed to meet the TSWTM at the location where wells were installed. However, surface saturation was observed during multiple site visits on portions of the site (Figure 8). At sample location A2, high water tables were detected during the periods of 3/06/16-3/09/16 and $03 / 11 / 16-03 / 20 / 16$. Data indicates that the water table dropped to 12.8 inches for 24 hours, below the threshold value of 12 inches required by the TSWTM. As a result, it remains highly likely that the TSWTM would be met at slightly lower elevations. Field observations of surface water at the study location supports this assumption. These findings highlight the importance of selecting appropriate locations for well placement and the need to conduct regular site visits to verify monitoring data. 
Figure 8. A2 site visit photograph depicting high water table and surface soil saturation in lower elevation portion of study area.

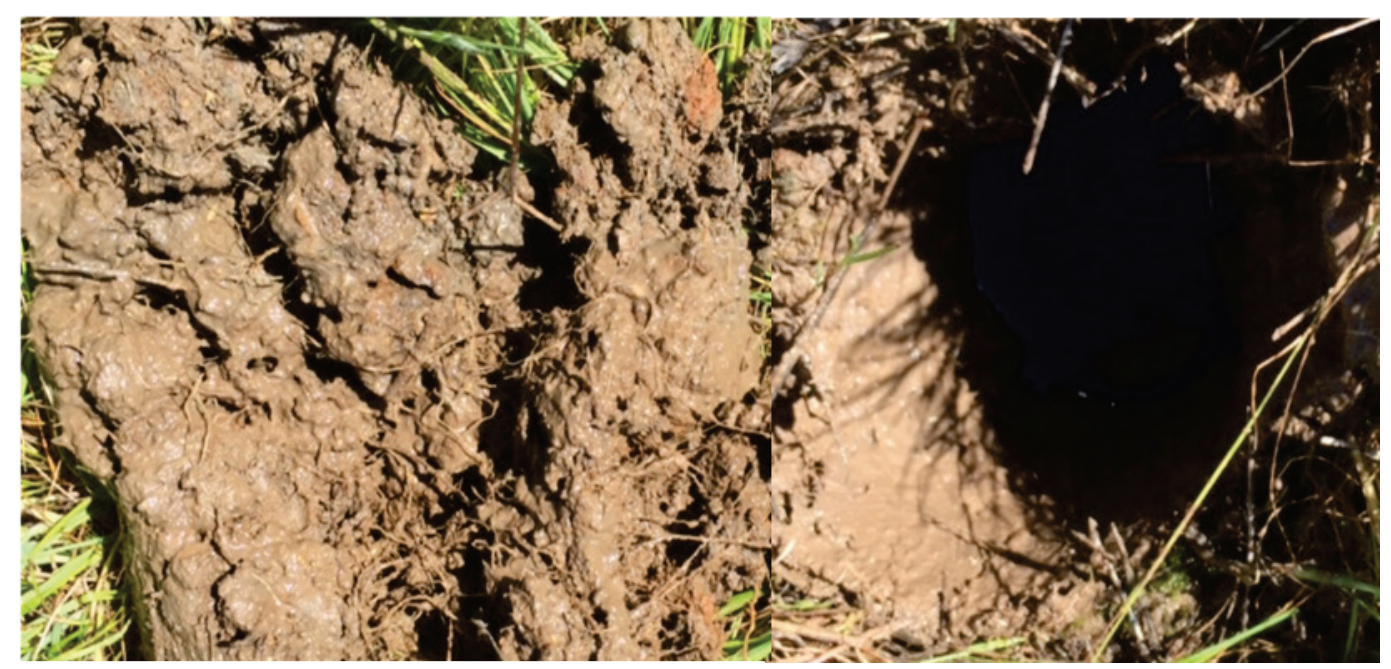

Site visits were conducted throughout the monitoring period to download data loggers, conduct maintenance, verify monitoring well data, and document on-site conditions. On-site evaluation included determinations of the spatial extent of high water tables (i.e., soil saturation within 12 inches of the soil surface). A site visit was conducted 20-21 March 2016, 14 days after a >2.0 inch rain event which resulted in high water tables at each of the 13 study locations. Monitoring well data confirmed that high water tables were maintained from the time of the rain event through the site visit, allowing for examination of site conditions immediately after the period when the TSWTM had been met (see discussion above regarding A2).

Staff utilized GPS, soil probes, range finders, and measuring tapes to verify the spatial extent of wetland hydrology (Figure 9; Appendix B). At five of the study locations, no difference was detected in the area displaying wetland hydrology when comparing off-site and field verified information (Table 7). At the remainder of monitoring locations, the off-site analysis underestimated the area displaying wetland hydrology. The observed differences between on-site and off-site data likely result from the difficulty in identifying subsurface soil saturation when evaluating aerial images. However, analysis of off-site sources does provide a valuable tool for identifying areas in which wetland hydrology is likely to persist following removal of irrigation inputs, especially when applying the approaches outlined in Berkowitz et al. (2016). These findings highlight the benefit of using off-site sources to evaluate the potential presence of wetlands in conjunction with on-site data collection to refine the location of wetland boundaries and verify the results of image interpretation. 
Conducting site visits during the normal wet portion of the year, within approximately 14 days after a rain event, provides a reliable approach to evaluate the longevity of wetland hydrology, verify the presence of wetlands, and determine the spatial extent of wetland boundaries. However, practitioners should consider and document the amount of precipitation along with recent and longer term (e.g., drought) climate conditions when scheduling and executing field activities. In the absence of a field site visit conducted under these conditions, data from Berkowitz et al. (2016) and the current study suggest image interpretation offers an approach to identifying areas in which wetland conditions would likely persist following removal of irrigation waters. However, utilizing off-site sources as the only tool to identify wetlands and determine their boundaries may result in identification of less wetland acreage, and represent a conservative approach.

Figure 9. Comparison of wetland extent as determined by image interpretation (left) and on-site verification (right).
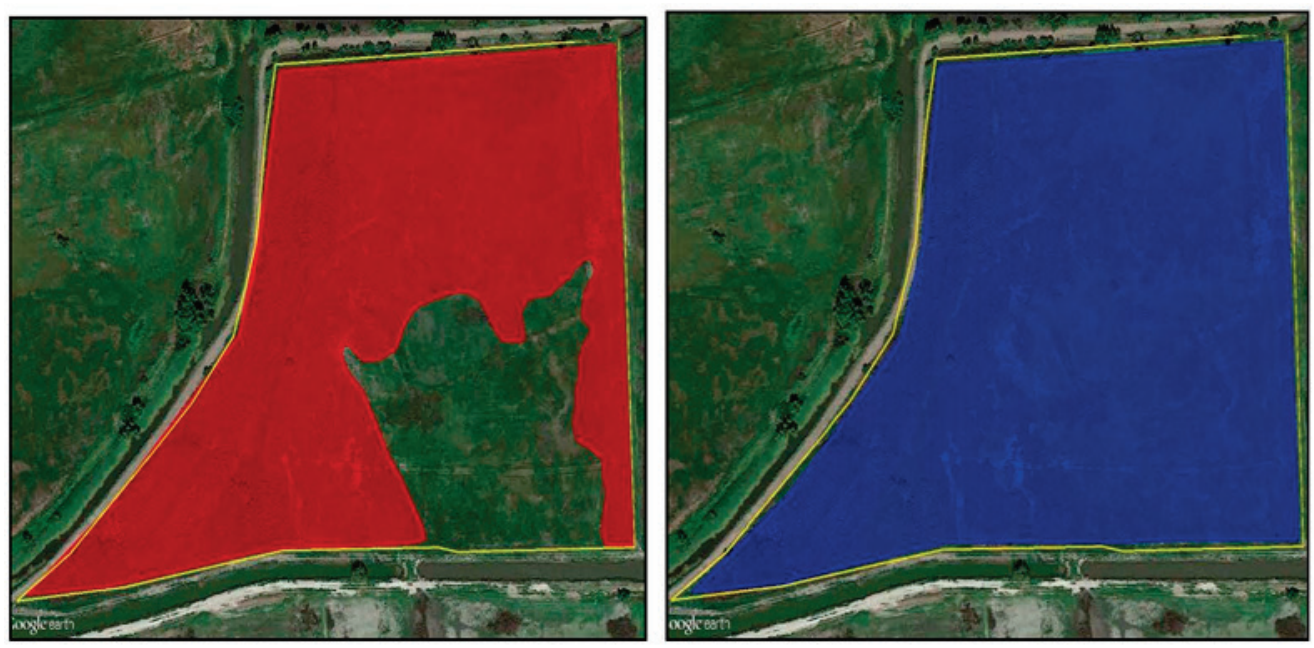

Table 7. Comparison of off-site and field verified spatial extent of wetland hydrology.

\begin{tabular}{|c|c|c|c|}
\hline \multirow{2}{*}{ Site } & \multicolumn{3}{|c|}{ Spatial extent of wetland hydrology (acres) } \\
\cline { 2 - 4 } & Field verified analysis & Off-site analysis & Difference \\
\hline A1 & 3.81 & 3.19 & -0.62 \\
\hline A2 & 4.53 & 4.53 & 0.00 \\
\hline A3 & 4.94 & 3.00 & -1.94 \\
\hline A4 & 29.4 & 29.4 & 0.00 \\
\hline A5 & 3.14 & 3.14 & 0.00 \\
\hline A6 & 29.4 & 29.4 & 0.00 \\
\hline
\end{tabular}




\begin{tabular}{|c|c|c|c|}
\hline \multirow{2}{*}{ Site } & \multicolumn{3}{|c|}{ Spatial extent of wetland hydrology (acres) } \\
\cline { 2 - 4 } & Field verified analysis & Off-site analysis & Difference \\
\hline R1 & 12.2 & 6.83 & -5.37 \\
\hline N1 & 6.74 & 3.10 & -3.64 \\
\hline T1 & 0.99 & 0.99 & 0.00 \\
\hline G8-1 & 20.7 & 13.9 & -6.8 \\
\hline G8-2 & 15.5 & 8.72 & -6.78 \\
\hline G9 & 18.1 & 15.4 & -2.7 \\
\hline G27 & 8.35 & 6.10 & -2.25 \\
\hline
\end{tabular}

\subsection{Interpretation of results}

Results indicate that 12 of the 13 formerly irrigated areas examined in the current study displayed wetland conditions during the 2015-2016 water year. The fact that high water table events were observed 1) during normal or drier than normal periods and 2) following an extended period of drought, promotes confidence that the study locations would display wetland hydrology with a frequency and duration sufficient to meet TSWTM criteria. These findings suggest that wetland hydrology can persist in some formerly irrigated areas following the removal of supplemental water applications. However, careful analysis conducted on a case-by-case basis is required due to the variety of site conditions observed across the region, patterns of climate, land use history, and other factors.

As noted above, study locations were selected based upon potential wetness signatures in aerial images, low elevation areas identified utilizing LiDAR, and other evidence that wetland conditions may be present. As a result, these findings should not be directly extrapolated to landscape scales. For example, several monitoring locations in the current study only exhibited wetland conditions across a portion of the study area. However, results clearly demonstrate that wetland conditions can persist in the absence of irrigation inputs in some areas. The potential for wetlands to persist should be considered when irrigated areas are converted to other land uses subject to USACE permitting and regulation.

\subsection{Framework for wetland delineation in formerly irrigated areas}

The current report investigates the capacity of formerly irrigated areas to exhibit wetland conditions following the removal of supplemental water inputs. Investigations focus on the presence of wetland hydrology during 
the normal wet portion of the year, in normal or drier than normal rainfall periods. This approach builds upon guidance provided in the Corps of Engineers Wetland Delineation Manual (Environmental Laboratory 1987) and associated regional supplements which address wetland determinations conducted in altered and difficult situations, including image analysis, rainfall normality, and direct hydrological monitoring. As a result, the following procedure is proposed.

1. Off-site analysis is utilized to identify potential wetness signatures as described in Berkowitz et al. (2016), in which image interpretation is conducted and seasonality and rainfall conditions are considered. In some cases, wetness signatures may be absent, reducing the need for further investigation. Conversely, areas showing obvious wetness signatures that persist over time and display clear, abrupt boundaries may be delineated using off-site sources with little field verification. However, most evaluations require a combination of on-site and off-site approaches.

2. On-site field evaluations are utilized to verify off-site results and refine potential wetland boundaries. Timing of site visits is critical and should occur within approximately 14 days after rain events, with consideration of short and long term climatic conditions. Appropriate timing of site visits provides a reliable approach to evaluate the longevity of wetland hydrology. Site visits should focus on the documentation of high water tables and determination of the spatial extent of wetland hydrology (i.e., water within 12 inches of the soil surface) and associated wetland boundaries. On-site data should be compared with off-site data to determine the overall extent of wetlands expected to persist over time.

3. If additional information is needed, direct monitoring of water tables and rainfall can further document the presence of wetlands and delineation of wetland boundaries. Wetland hydrology monitoring should follow techniques and procedures outlined in the current report in accordance with the TSWTM (USACE 2005). Care must be taken to ensure that monitoring equipment is installed in the appropriate location, based upon results of off-site analysis and ground conditions. Further, monitoring data should be examined to ensure that irrigation activities in nearby ditches or adjacent fields is not influencing results.

Other potential approaches (not examined herein) to evaluating wetland conditions in formerly irrigated areas could include the application of alpha-alpha dipyridyl dye, installation of platinum electrodes, or Indicator of Reduction in Soils (IRIS) tubes to document hydric soil functions are 
currently occurring (Berkowitz and Noble 2015). Additionally, long term monitoring of plant communities using the prevalence index can determine if plant communities are shifting toward wetter or drier assemblages (USACE 2005). These approaches also depend on seasonal and long term climate fluctuations; however, when utilized in the framework outlined above, these techniques may provide additional information for identifying wetlands in formerly irrigated areas. 


\section{Summary}

The majority (12 of 13) of the study locations examined met the TSWTM and associated wetland criteria based upon onsite water table monitoring and analysis of rainfall normality. Results demonstrate that wetland hydrology can persist in portions of the study area due to natural patterns of precipitation following removal of irrigation applications. Wetland hydroperiods ranged from 14-37 days. In some cases, the frequency and duration of wetland hydrology may differ from unaltered wetlands in the region due to the degree of alteration (e.g., land-leveling, soil compaction) and other factors. High water table periods occurred during drier than normal and/or normal rainfall periods, following a historic drought period, suggesting that the extent of wetlands may expand during higher than normal rainfall periods and/or non-drought conditions. One location failed to meet the TSWTM due to a 24 hour decrease in water table elevation, highlighting the importance of monitoring well placement.

The findings support the application of aerial image interpretation as a tool to aid in wetland determinations as outlined in Berkowitz et al. (2016). Analysis conducted using off-site approaches yielded identical wetland acreages in 5 (38\%) of the areas examined when verified using on-site data. In some cases, estimated wetland acreages decreased when using off-site analysis only. Results suggest that off-site analysis provides valuable information regarding the presence or absence of wetland hydrology; however, on-site evaluations should be conducted to refine wetland boundaries and verify the findings derived from off-site approaches. The timing of site visits remains critical. Rainfall normality and seasonality should be considered throughout the delineation process including when conducting image interpretation, scheduling site visits, and during direct monitoring for application of the TSWTM. A framework has been proposed to aid in the identification and delineation of wetlands in formerly irrigated areas, complementing existing approaches including the Corps of Engineers Wetland Delineation Manual (Environmental Laboratory 1987), associated regional supplements, and guidance provided in USACE (2012). This procedure has proven to be effective for evaluating hydrology and assisting with the identification and delineation of a variety of wetland types in multiple land use scenarios. The information generated is a valuable tool to further document the administrative record in support of wetland determinations. 


\section{References}

Berkowitz, J. F., J. Pietroski, and D. Krenz. 2016. Identifying areas of potential wetland hydrology in irrigated croplands using aerial image interpretation and analysis of rainfall normality. ERDC/EL TR-16-6. Vicksburg, MS: U.S. Army Engineer Research and Development Center.

Berkowitz, J. F., and C. V. Noble. 2015. Development of new hydric soil field indicators: Guidelines for data collection and submission. Soil Horizons 56(1).

Berkowitz J. F., S. Page, and C. V. Noble. 2014. Potential disconnect between observations of hydrophytic vegetation, wetland hydrology indicators, and hydric soils in unique pitcher plant bog habitats of the southern Gulf Coast. Southeastern Naturalist 13(4):721-734.

Berkowitz, J. F., and D. Evans. 2014. A review of the recent scientific literature on irrigation induced and enhanced wetlands. ERDC/EL TN-14-5. Vicksburg, MS: U.S. Army Engineer Research and Development Center.

Department of Ecology. 2010. Focus on irrigation-influenced wetlands. Olympia, Washington: State of Washington Department of Ecology. https://fortress.wa.gov/ecy/publications/SummaryPages/1006015.html

Environmental Laboratory. 1987. Corps of Engineers wetland delineation manual. U.S. Army Corps of Engineers. Wetland Research Program Technical Report Y-87-1. Vicksburg, MS: U.S. Army Engineer Research and Development Center.

Ekstein, J. D., and S. Hygnstrom. 1996. Fate of wetlands associated with the central Nebraska irrigation canal system. Great Plains Research 6:41-60.

Fujii, R. 1998. Dissolved organic carbon concentrations and compositions, and trihalomethane formation potentials in waters from agricultural peat soils, Sacramento-San Joaquin Delta, California: Implications for drinking-water quality. US Geologic Survey, Sacramento, CA.

Hanes T., and L. Stromberg. 1998. Hydrology of vernal pools on non-volcanic soils in the Sacramento Valley. Eds. C. W. Witham, E. T. Bauder, D. Belk, W. R. Ferren Jr., and R. Ornduff. Ecology, Conservation, and Management of Vernal Pool Ecosystems - In proceedings from a 1996 Conference. California Native Plant Society, Sacramento, CA.

Kendy, E., and J. D. Bredehoeft. 2006. Transient effects of groundwater pumping and surface-water-irrigation returns on streamflow. Water Resources Research $42(8)$.

National Technical Committee for Hydric Soils (NTCHS). 2015. Hydric soils technical note 11: Hydric soils technical standard and data submission requirements for field indicators of hydric soils. Washington, DC: United States Department of Agriculture (USDA), NRCS. 
Nikiforoff C. C. 1941. Hardpan and micro relief in certain soil complexes of California. U.S. Department of Agriculture Technical Bulletin No. 745. U.S. Government Printing Office: Washington, DC.

Pyke, C. R., and Marty, J. 2005. Cattle grazing mediates climate change impacts on ephemeral wetlands. Conservation Biology 19(5):1619-1625.

Rains, C. M., Fogg, G. E., Harter, T., Dahlgren, R. A., and Williamson, R. J. 2006. The role of perched aquifers in hydrological connectivity and biogeochemical processes in vernal pool landscapes, Central Valley, California. Hydrological Processes 20(5):1157-1175.

Simon Wang S. Y., Y. H. Lin, R. R. Gillies, and K. Hakala. 2016. Indications for protracted groundwater depletion after drought over the Central Valley of California*. Journal of Hydrometeorology 17(3):947-955.

Silveira J. G. 1998. Avian uses of vernal pools and implications for conservation practice. Eds. C. W. Witham, E. T. Bauder, D. Belk, W.R. Ferren Jr., and R. Ornduff. Ecology, Conservation, and Management of Vernal Pool Ecosystems - In proceedings from a 1996 Conference. California Native Plant Society, Sacramento, $C A$.

Soil Survey Staff, Natural Resources Conservation Service, United States Department of Agriculture. Web Soil Survey. Available online at http://websoilsurvey.nrcs.usda.gov/. (Accessed 09/02/2016).

Sprecher, S. W., and A. G. Warne. 2000. Accessing and using meteorological data to evaluate wetland hydrology. ERDC/EL TR-WRAP-oo-1. Vicksburg, MS: U.S. Army Engineer Research and Development Center.

Strange, E. M., K. D. Faush, and A. P. Covich. 1999. Sustaining ecosystem services in human-dominated watersheds: Biohydrology and ecosystem processes in the South Platte River Basin. Environmental Management 24(1):39-54.

Sueltenfuss, J., D. Cooper, R. Knight, and R. Waskom. 2013. The creation and maintenance of wetland ecosystems from irrigation canal and reservoir seepage in a semi-arid landscape. Wetlands 33(5):799-810.

Summerford, S. E. 2009. Characterization of soil/vegetation on flood irrigated hayfields in Grand Teton National Park, Wyoming: A predictive evaluation tool for agricultural wetlands. MS thesis, Montana State University.

Sumner, J. P., M. J. Vepraskas, R. K. Kolka. 2009. Methods to evaluate normal rainfall for short-term wetland hydrology assessment. Wetlands 29(3):1049-1062.

University of California. 1987. Determining daily reference evapotranspiration (Eto). Cooperative Extension, Division of Agriculture and Natural Resources, Leaflet 21426.

U.S. Army Corps of Engineers (USACE). 2005. Technical standard for water-table monitoring of potential wetland sites. ERDC TN-WRAP-05-02. Vicksburg, MS: U.S. Army Engineer Research and Development Center. 
U.S. Army Corps of Engineers (USACE). 2008. Regional supplement to the Corps of Engineers wetland delineation manual: Arid west region (Version 2.o). Eds. J. S. Wakeley, R. W. Lichvar, and C. V. Noble. ERDC/EL TR-08-28. Vicksburg, MS: U. S. Army Engineer Research and Development Center.

U.S. Army Corps of Engineers (USACE). 2010. Regional supplement to the Corps of Engineers wetland delineation manual: Western mountains, valleys, and coast region (Version 2.o). Eds. J. S. Wakeley, R. W. Lichvar, and C. V. Noble. ERDC/EL TR-10-3. Vicksburg, MS: U.S. Army Engineer Research and Development Center.

U.S. Army Corps of Engineers (USACE). 2012. Regulatory program wetlands determination and delineation procedures for irrigated lands. San Francisco, CA: U.S. Army Corps of Engineers. South Pacific Division.

U.S. Department of Agriculture - Natural Resources Conservation Service. 2006. Land Resource Regions and Land Resource Areas of the United States, the Caribbean, and the Pacific Basin. U.S. Department of Agriculture Handbook 296.

U.S. Department of Agriculture - Natural Resources Conservation Service (USDA-NRCS). 1997. Chapter 19 - Hydrology Tools for Wetland Determination. Part 650. Engineering Field Handbook.

Vepraskas M. J., K. L. Vaughan. 2016. Morphological feature of hydric and reduced soils. In Wetland soils: genesis, hydrology, landscapes, and classification. Eds. Vepraskas, M. J., Craft. Boca Raton, FL: CRC Press.

Web-based, Water-Budget, Interactive, Modeling Program (WebWIMP v. 1.01). 2003. Department of Geography, University of Delaware. http://climate.geog.udel.edu/ wimp/

Williams, A. P., R. Seager. J. T. Abatzoglou, B. I. Cook, J. E. Smerdon, and E. R. 2015. Contribution of anthropogenic warming to California drought during 2012-2014. Geophysical Research Letters 42(16): 6819-6828. 


\section{Appendix A: Monitoring Study Locations}
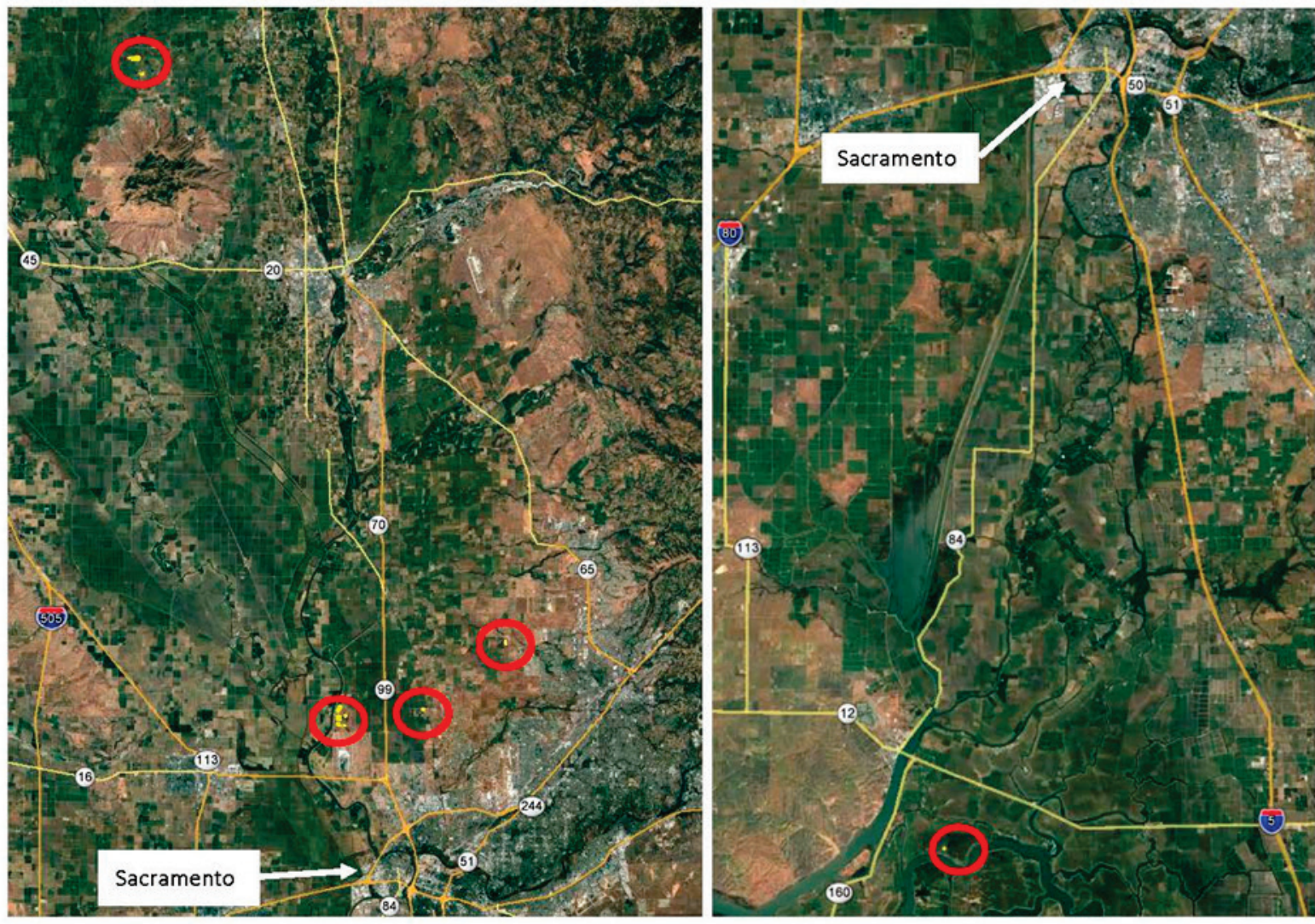


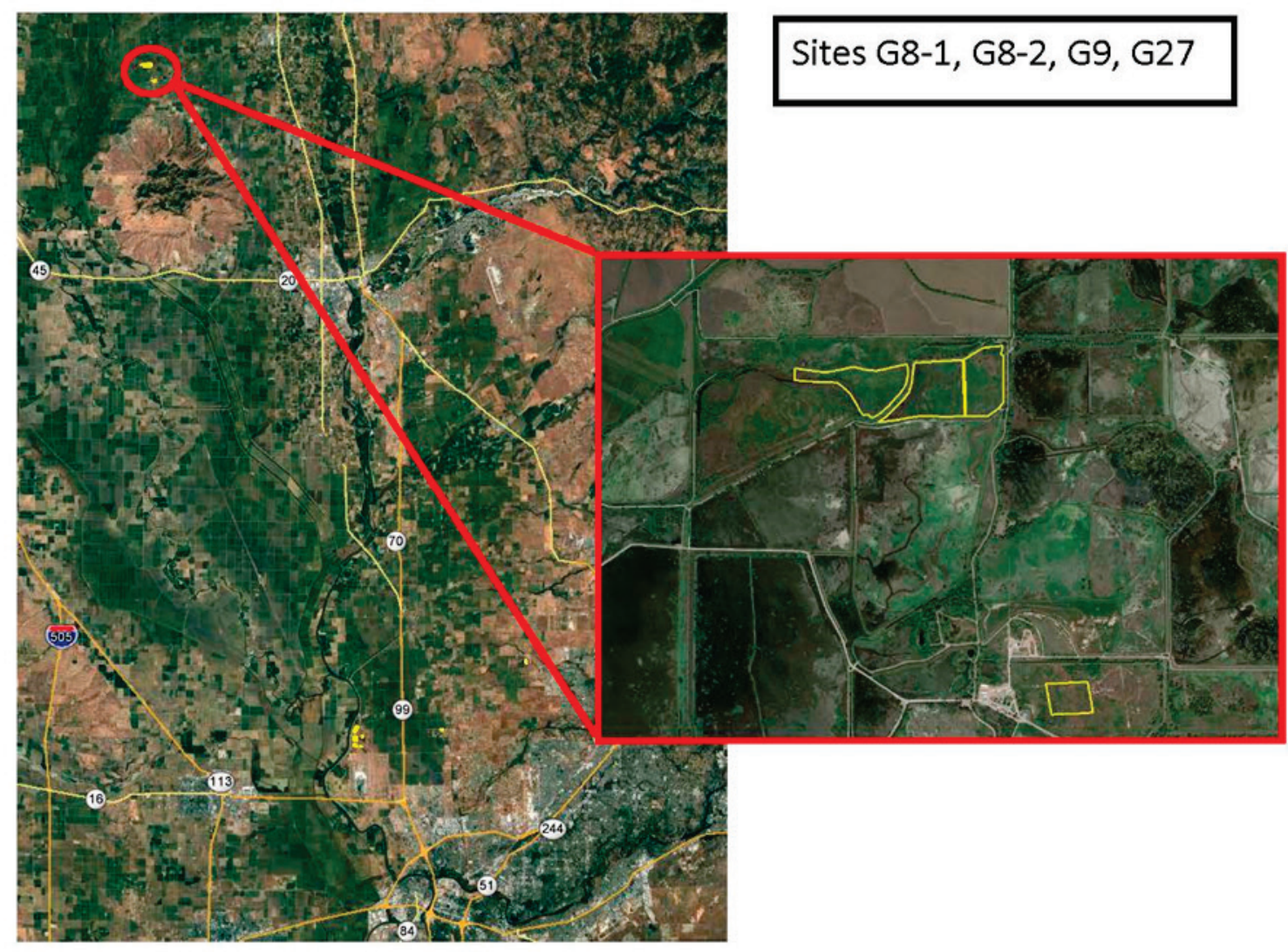




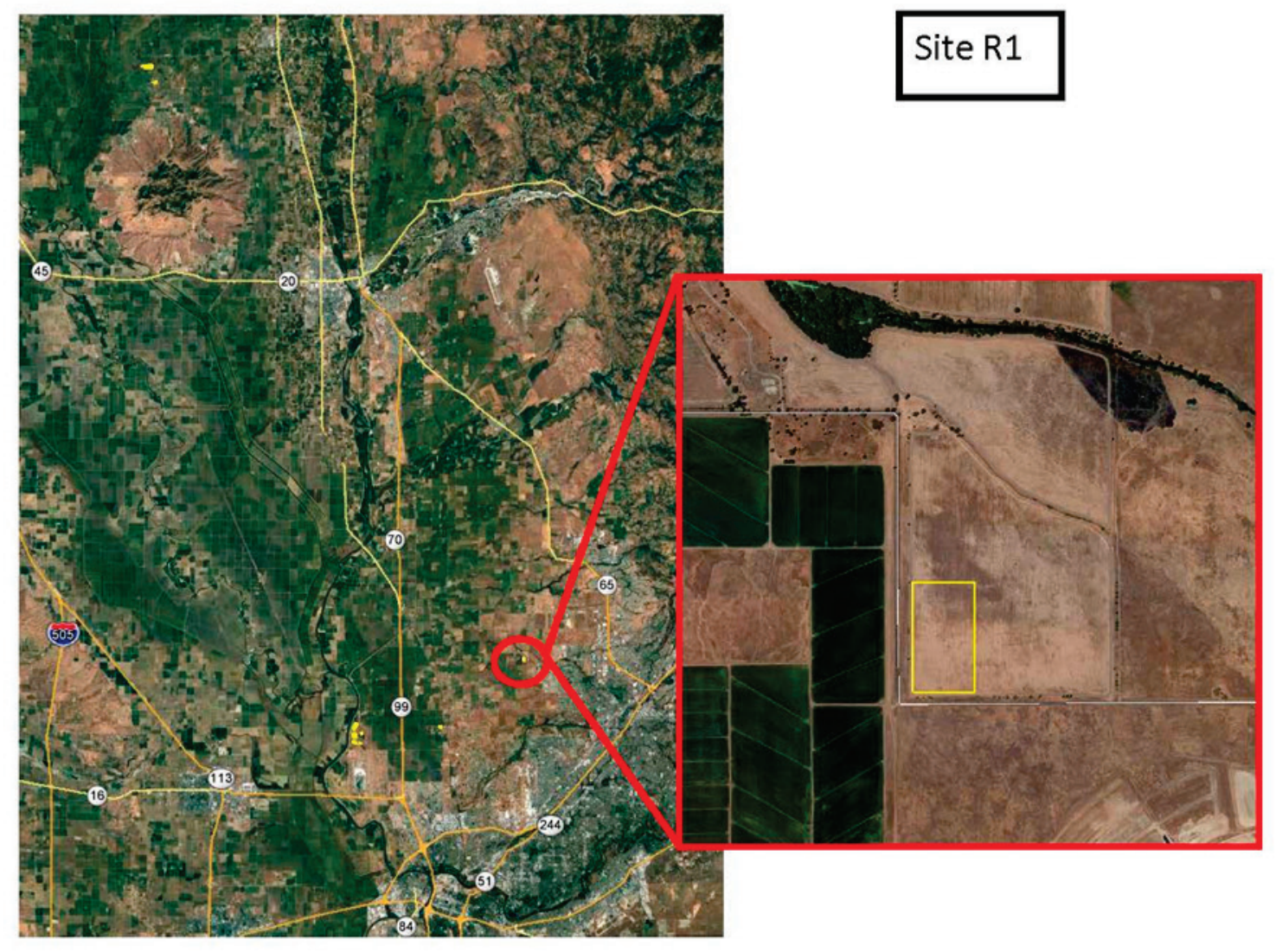




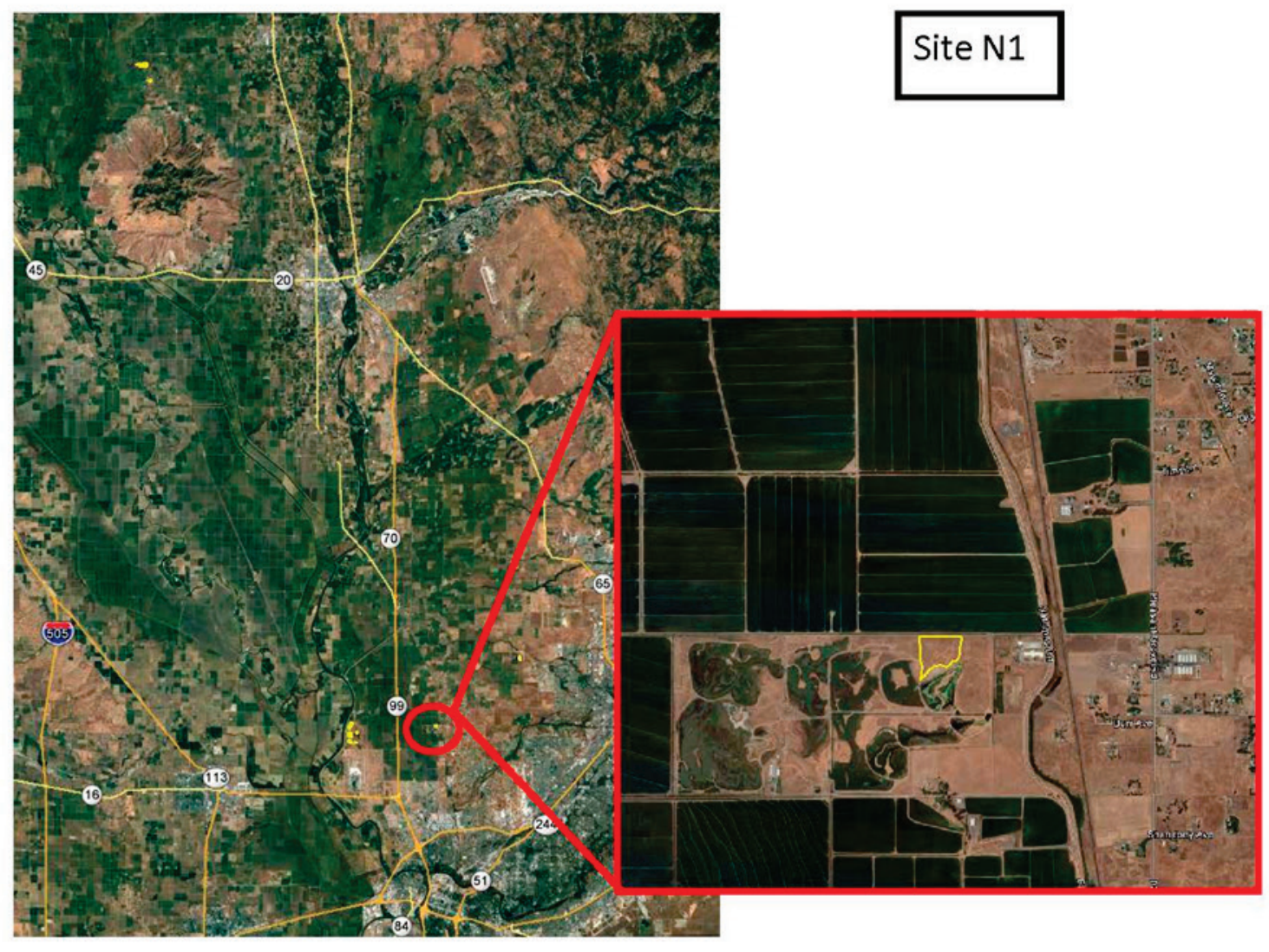




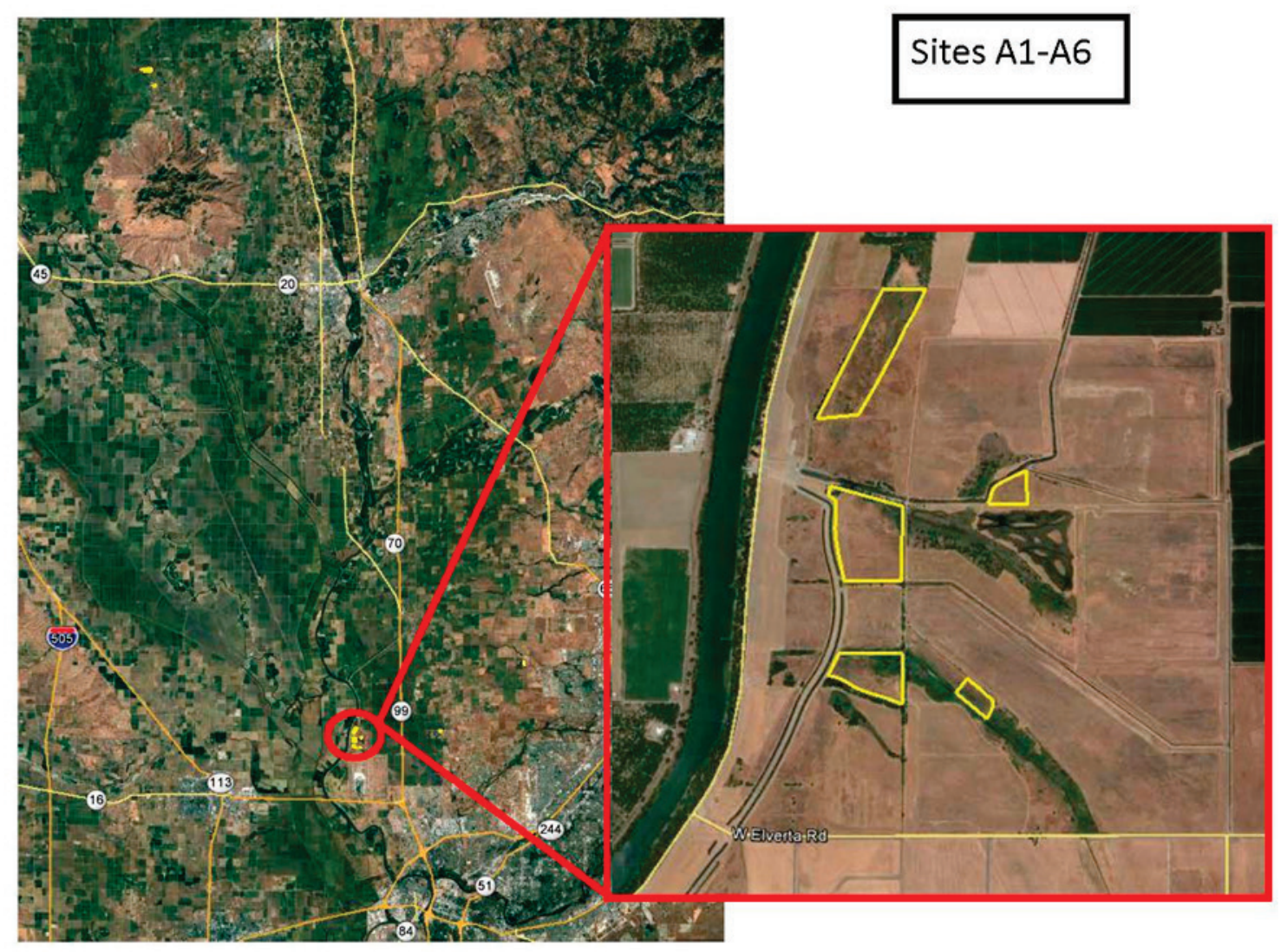




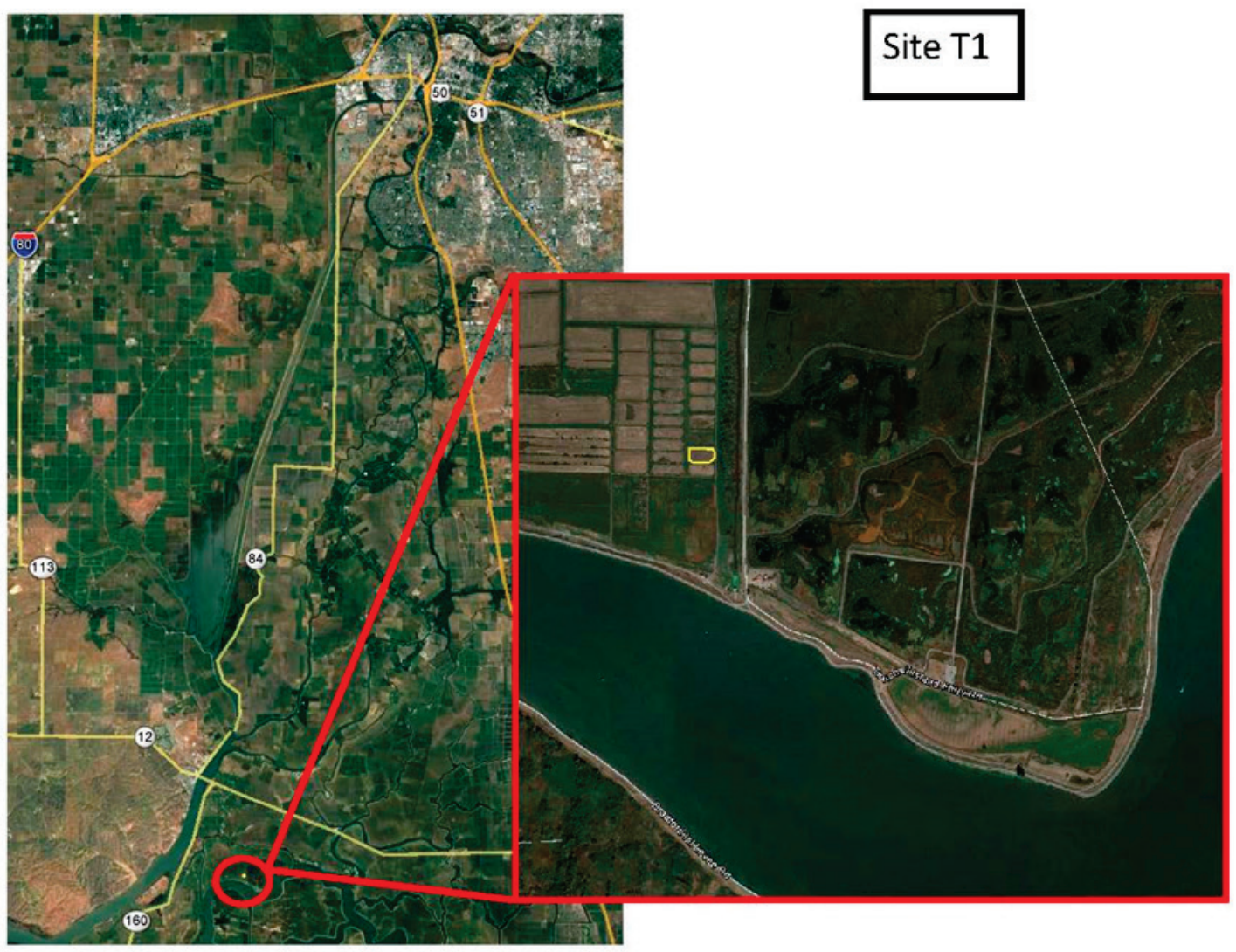




\section{Appendix B: Results Aerial Image Interpretation and Field Verification}

Field site photo, water table monitoring results, composite of wetland areas based on aerial image interpretation (red) and field verification (blue). 
Study location A1
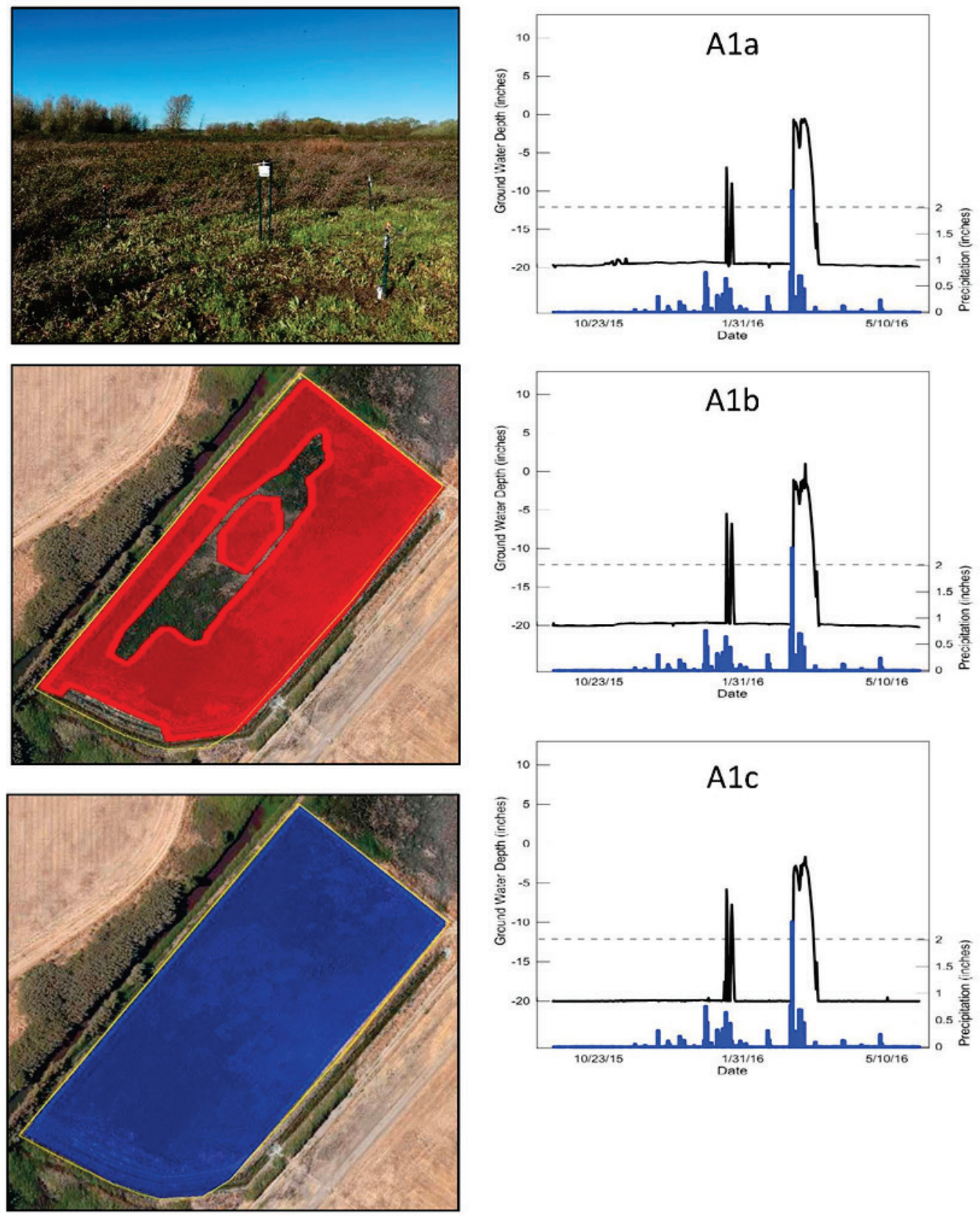
Study location A2
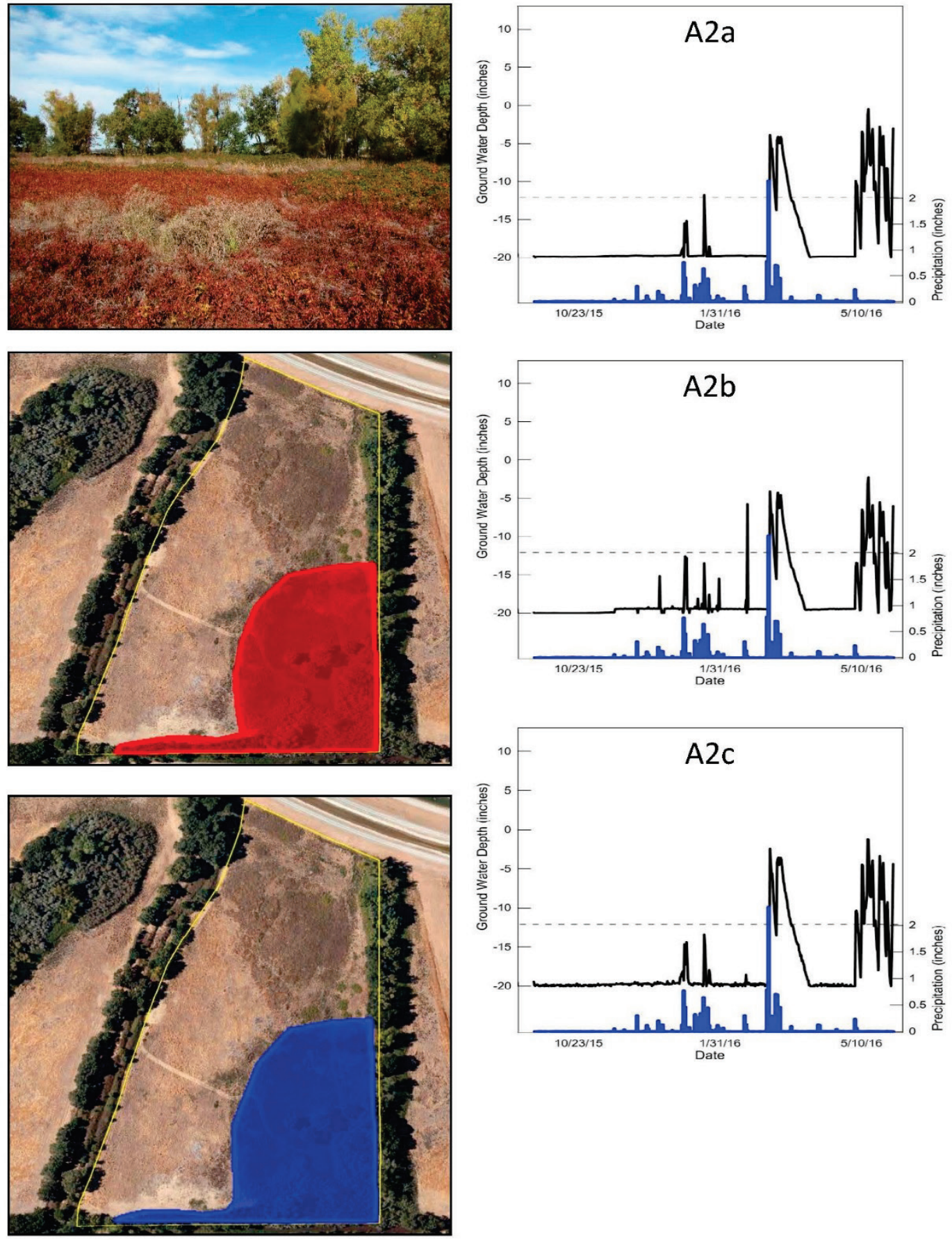
Study location $A 3$
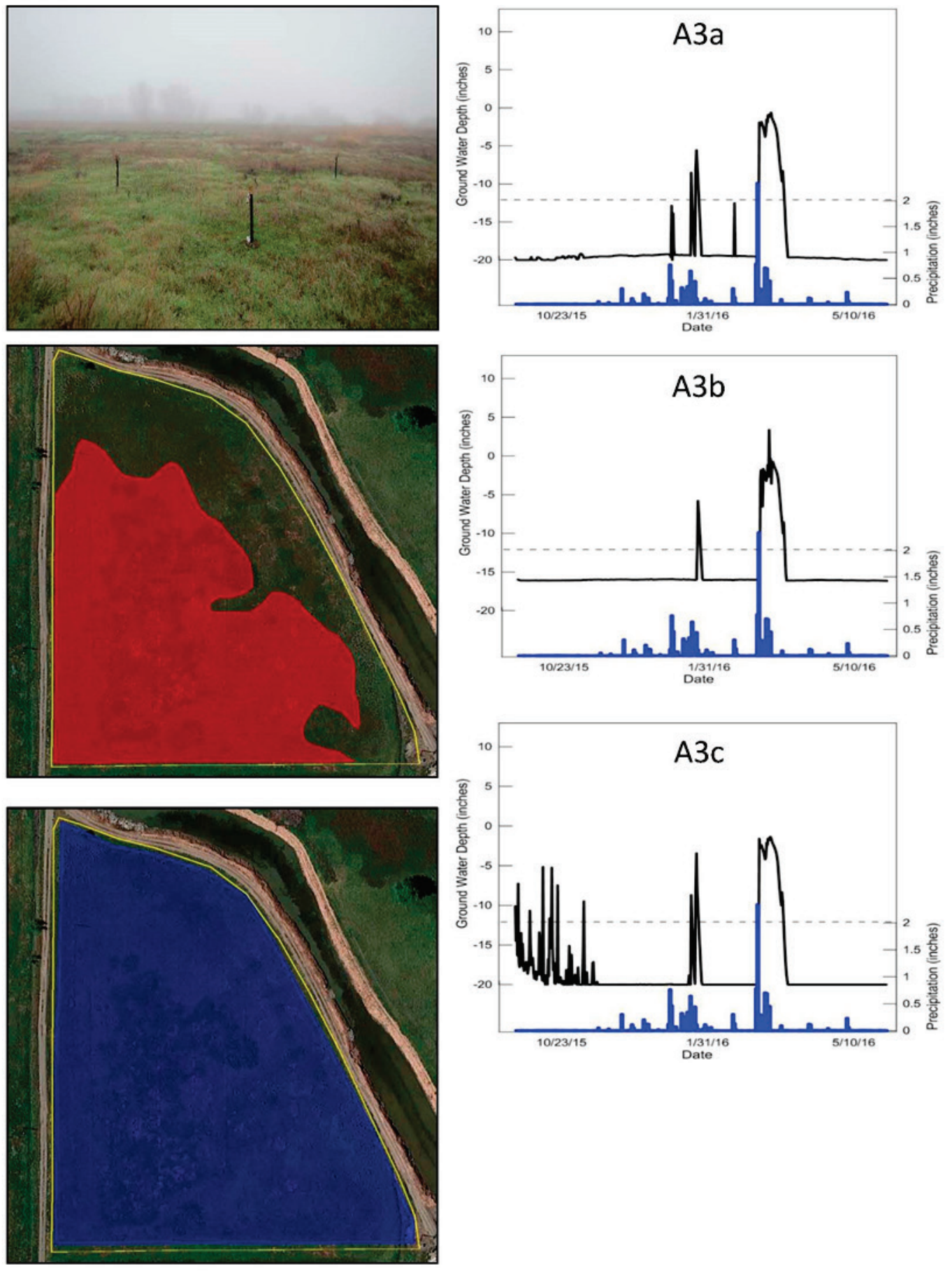
Study location A4
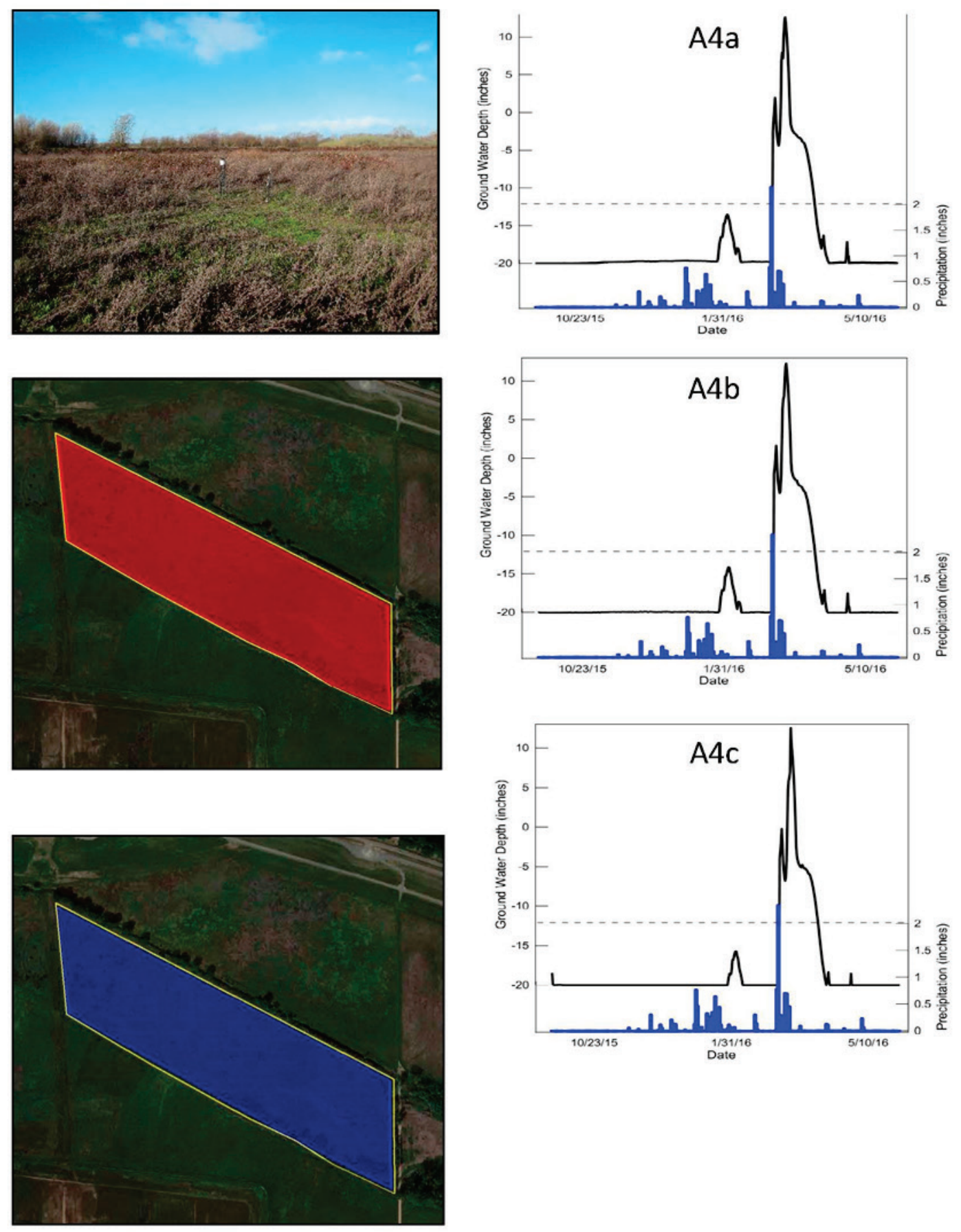
Study location A5
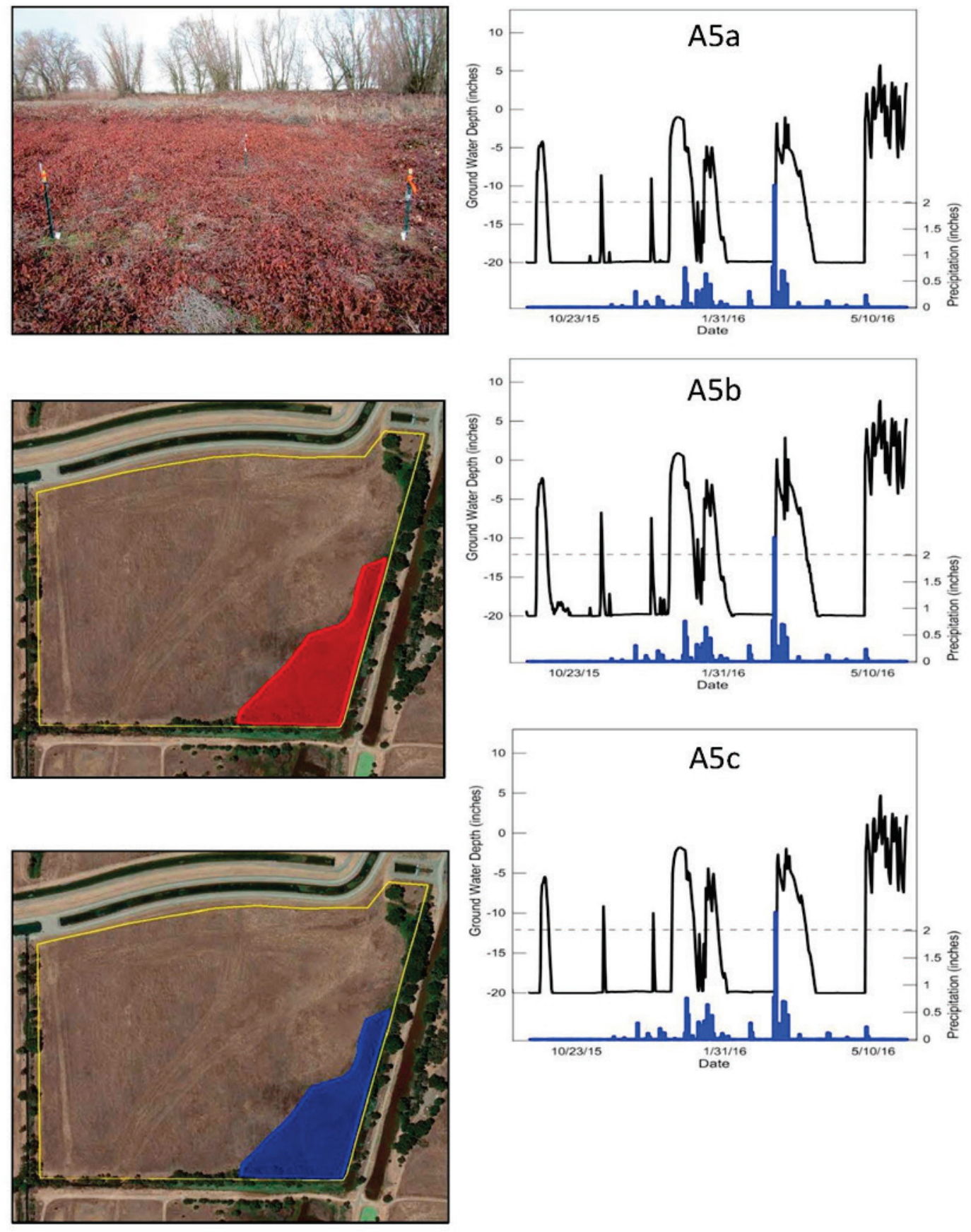
Study location A6
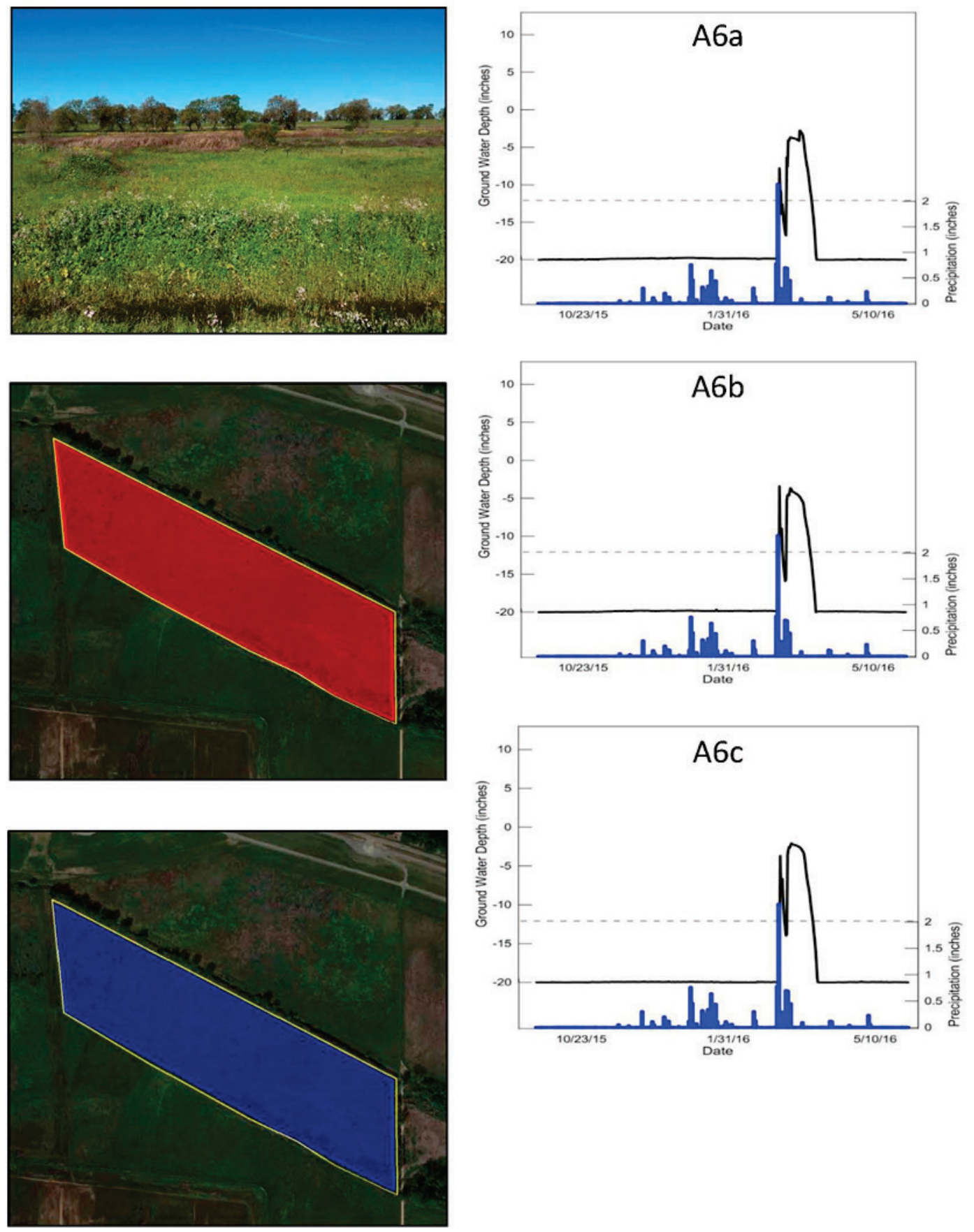
Study location G27
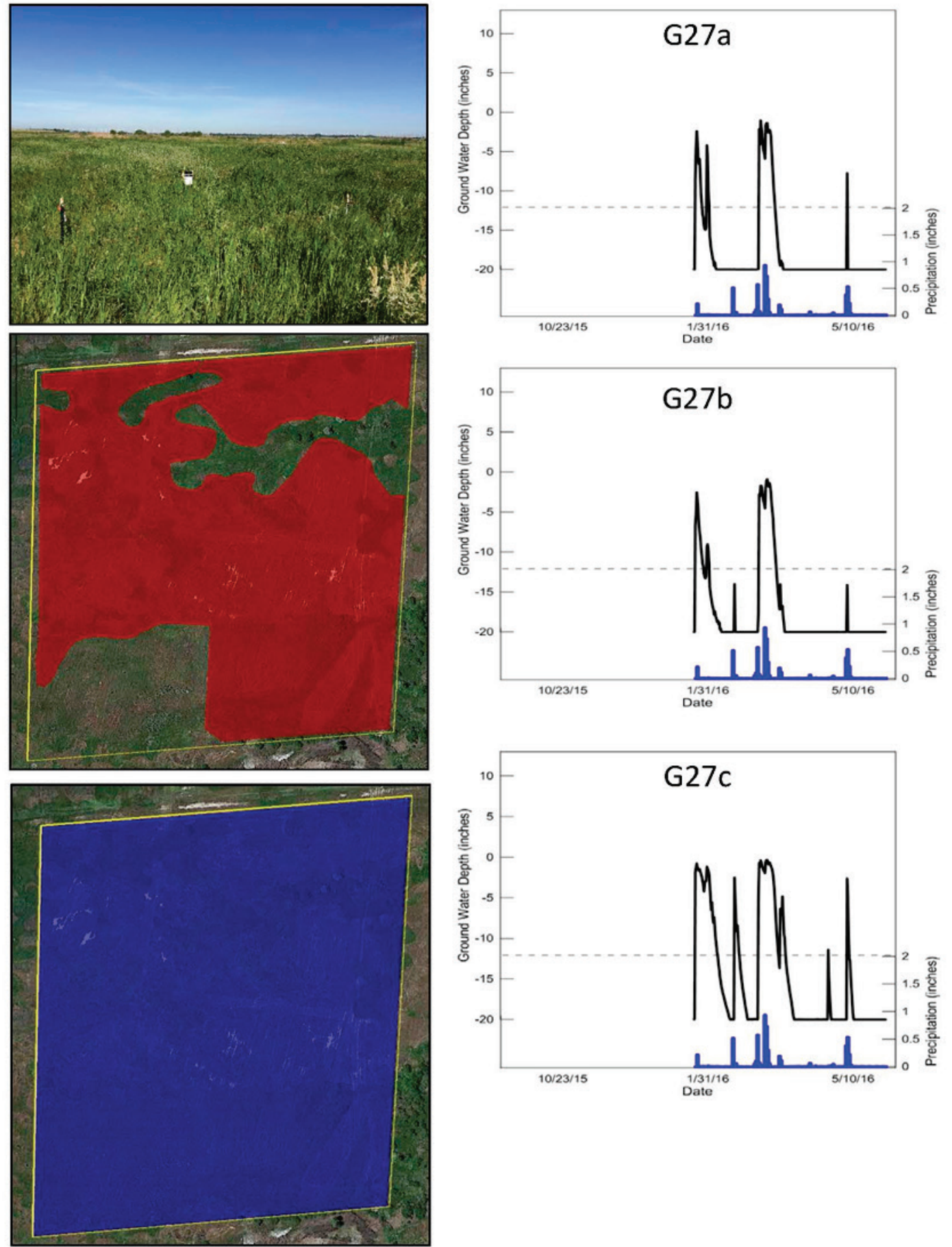
Study location G8-1
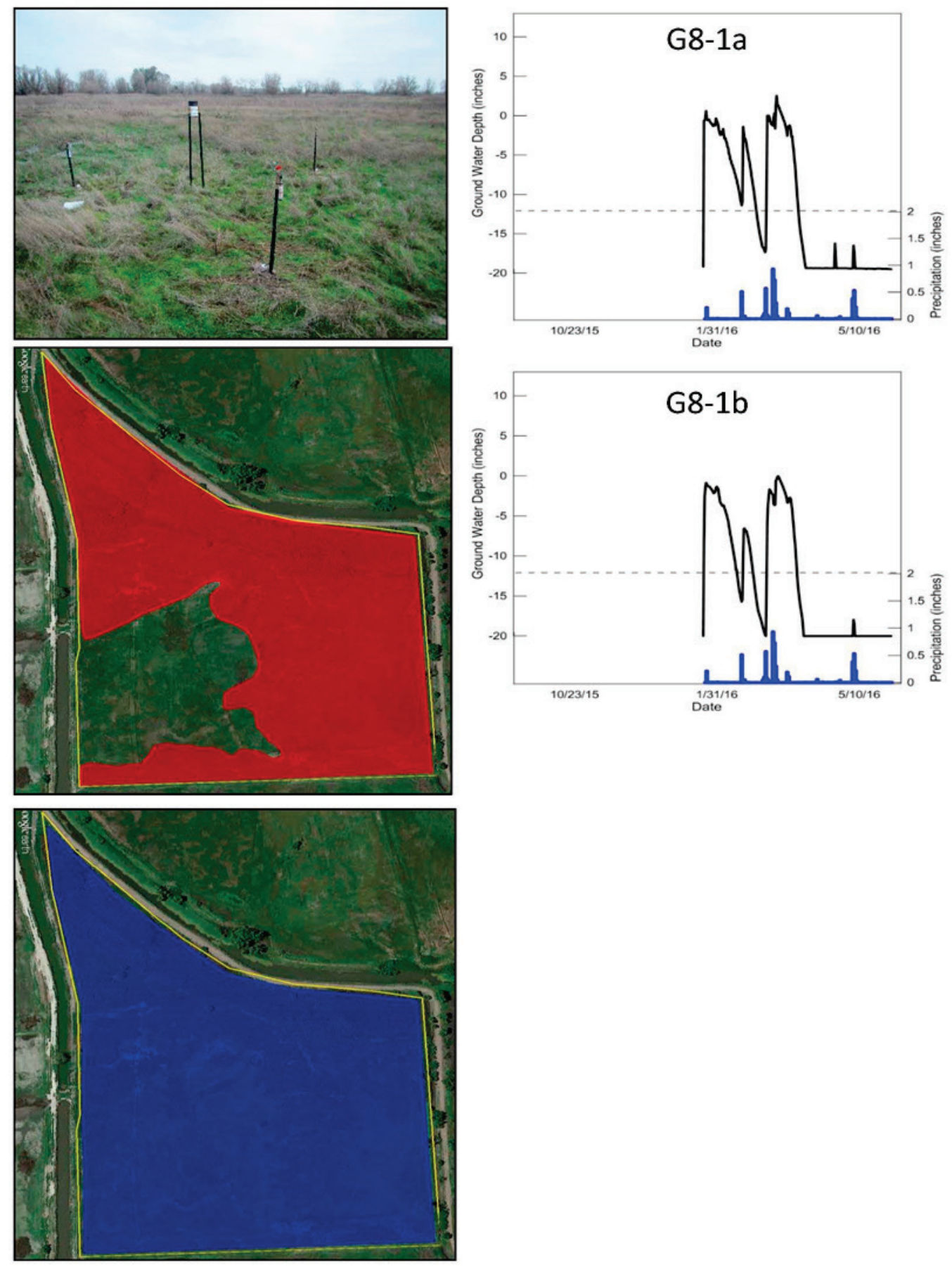
Study location G8-2

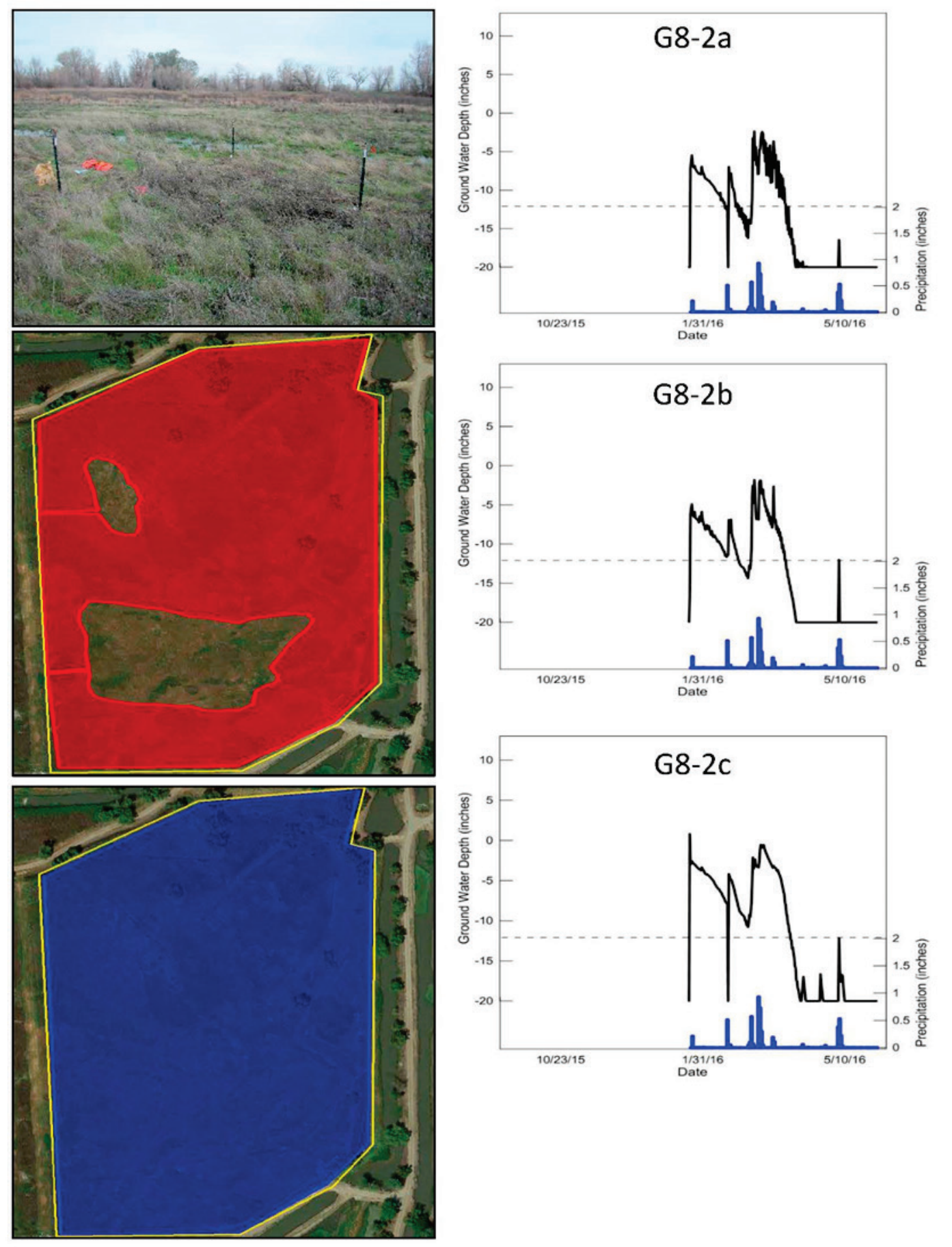


Study location G9
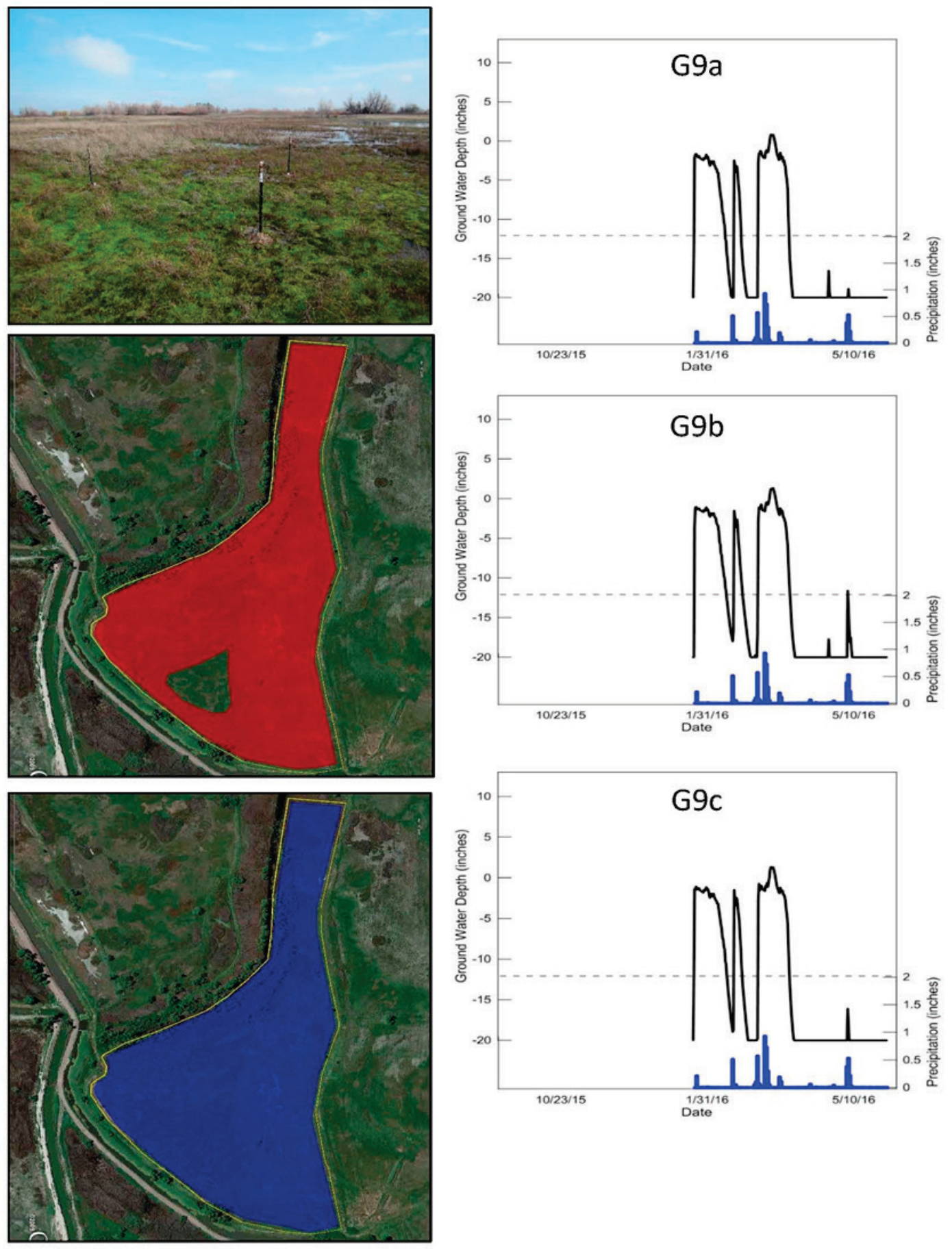
Study location $\mathrm{N}$
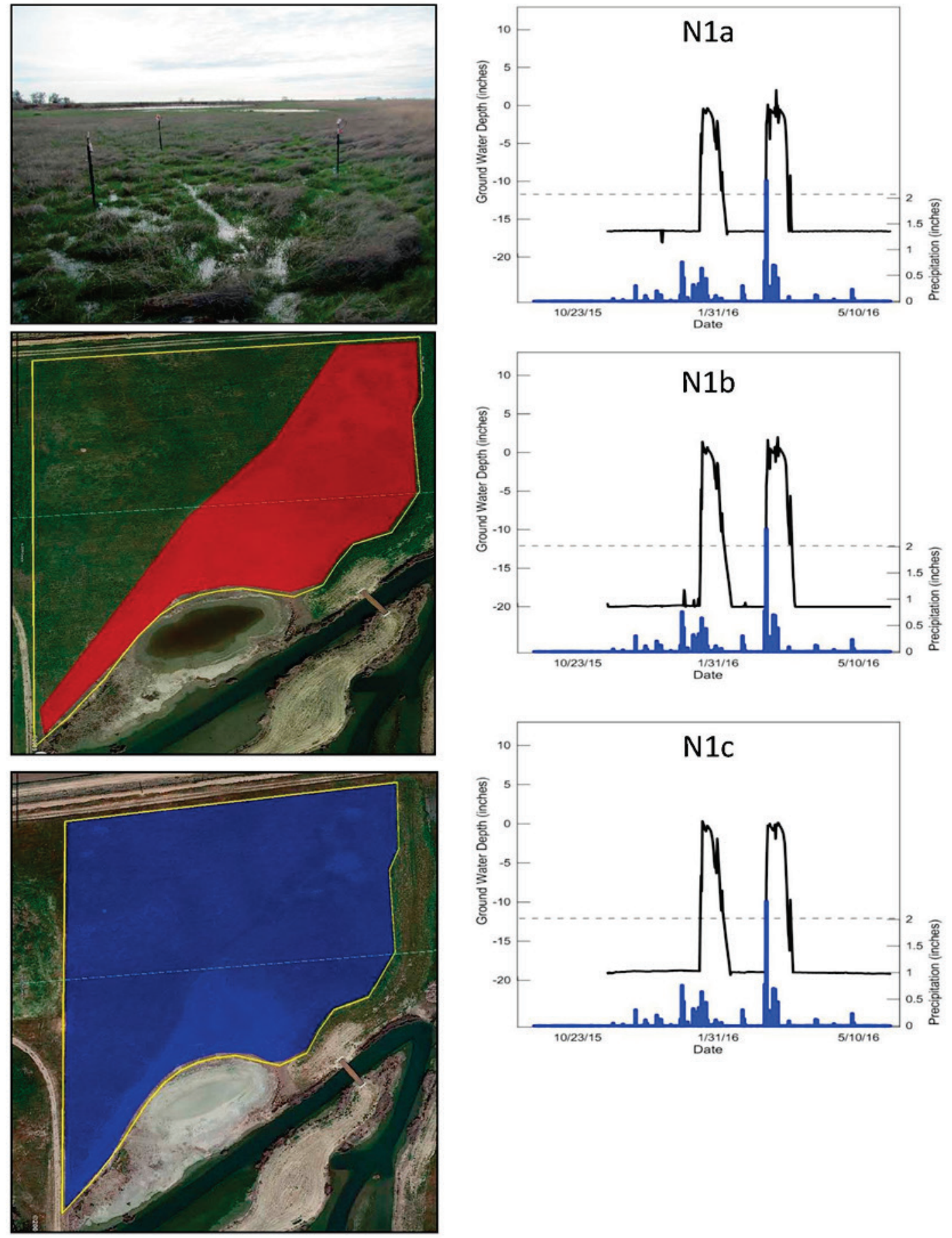
Study location $\mathrm{R}$
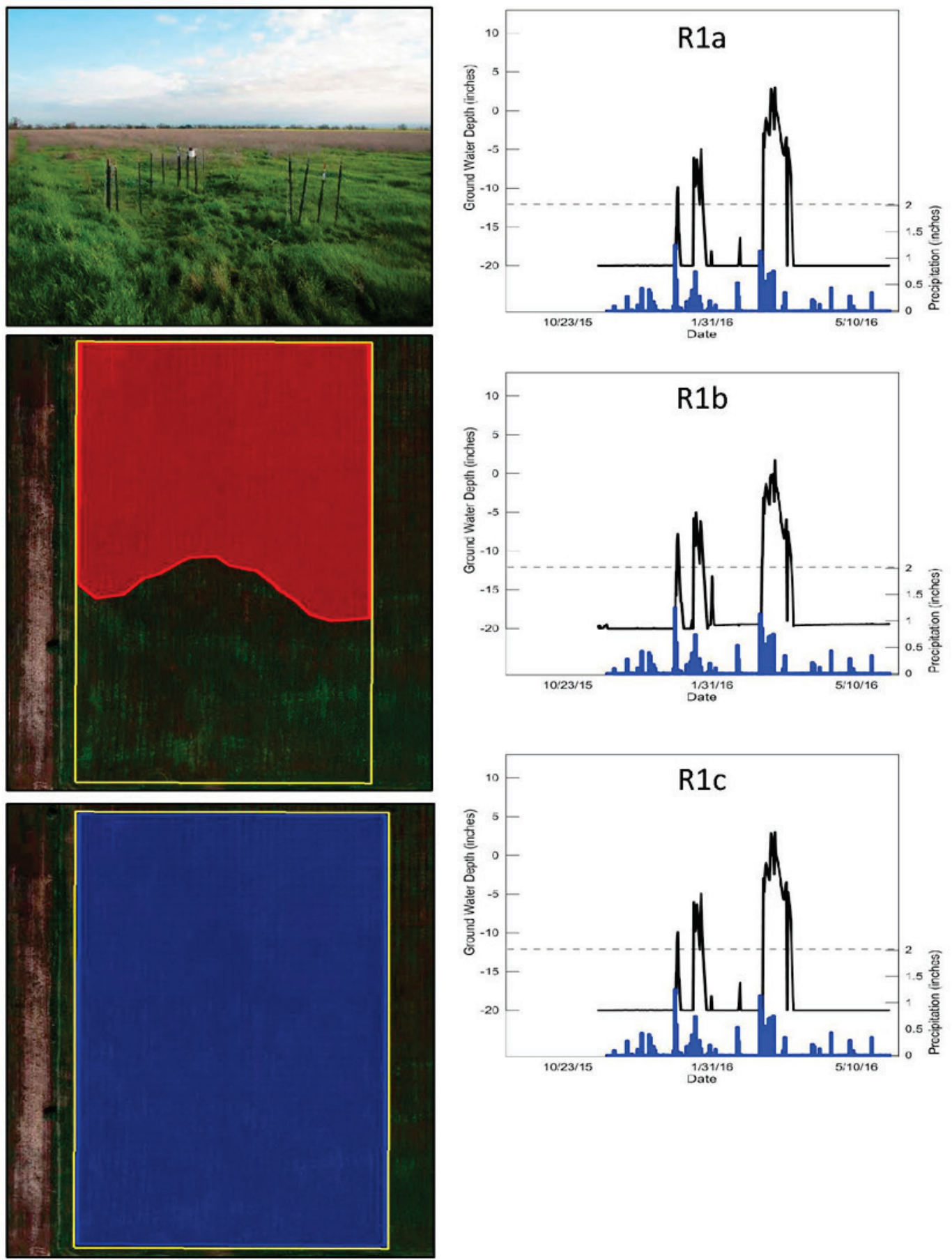
Study location $T$
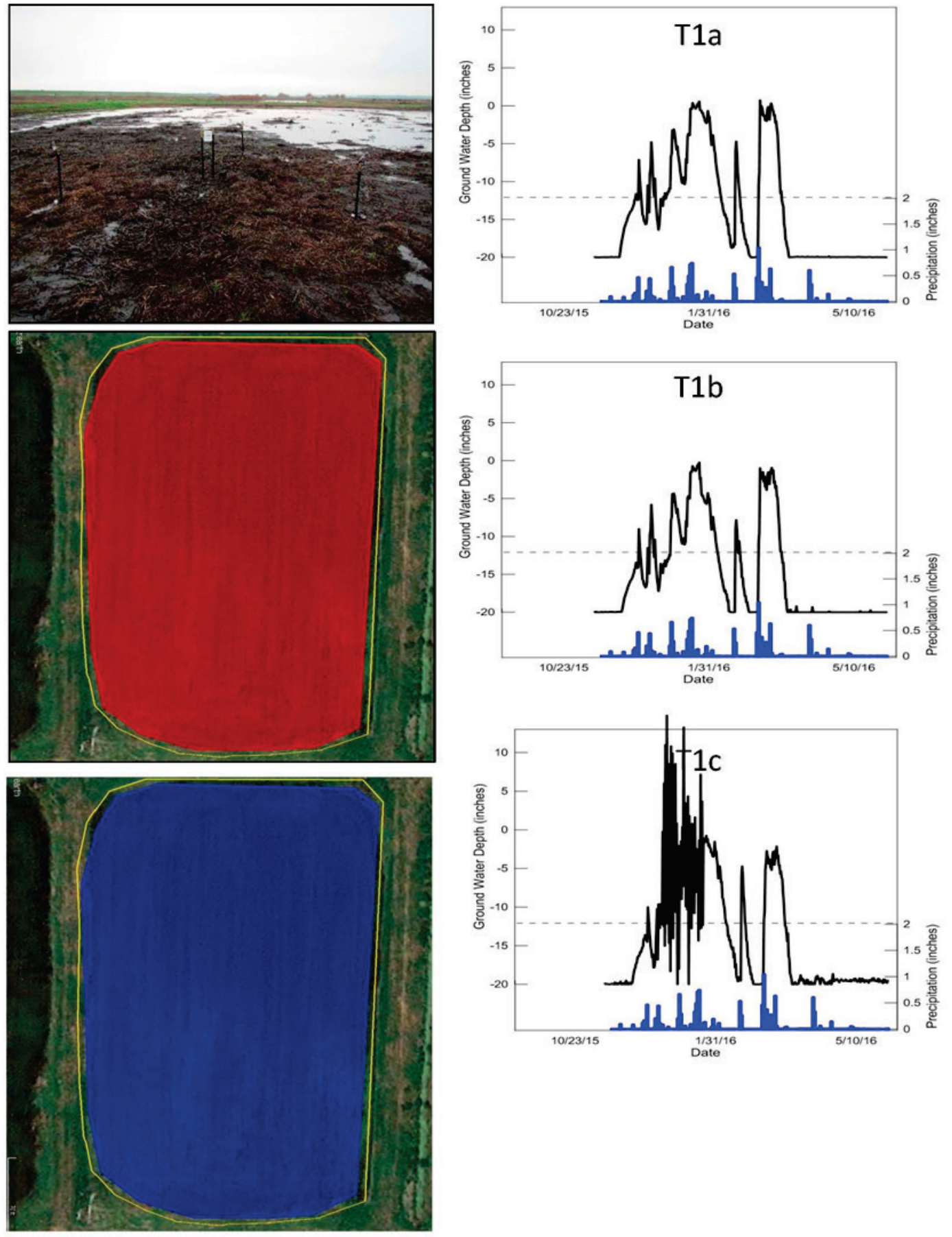


\section{Appendix C: Results of DAREM analysis for each study}

Study location A

\begin{tabular}{|c|c|c|c|c|c|c|c|c|c|c|}
\hline 2015 & & & & & & & & & & \\
\hline $\begin{array}{l}\quad \text { Prior Month } \\
\text { 3rd } \\
\text { 2nd } \\
\text { most recent } \\
\text { Month examined } \\
\end{array}$ & $\begin{array}{l}\text { Name } \\
\text { Jul } \\
\text { Aug } \\
\text { Sep } \\
\text { Oct } \\
\end{array}$ & $\begin{array}{c}\text { WETS 30th } \\
\text { percentile } \\
0.00 \\
0.00 \\
0.00\end{array}$ & $\begin{array}{c}\text { WETS 70th } \\
\text { percentile } \\
0.00 \\
0.00 \\
0.45\end{array}$ & $\begin{array}{c}\text { Measured } \\
\text { Rainfall } \\
0 \\
0 \\
0\end{array}$ & $\begin{array}{c}\text { Condition } \\
\text { Normal } \\
\text { Normal } \\
\text { Normal }\end{array}$ & $\begin{array}{c}\text { Condition } \\
\text { Value } \\
2 \\
2 \\
2\end{array}$ & $\begin{array}{c}\text { Month } \\
\text { Weight } \\
1 \\
2 \\
3 \\
\text { Total } \\
\end{array}$ & $\begin{array}{c}\text { Score } \\
2 \\
4 \\
6 \\
12 \\
\end{array}$ & NORMAL & $\begin{array}{l}\text { Dry }=6-9 \\
\text { Normal }=10-14 \\
\text { Wet }=15-19\end{array}$ \\
\hline \multicolumn{11}{|l|}{2015} \\
\hline $\begin{array}{l}\quad \text { Prior Month } \\
\text { 3rd } \\
\text { 2nd } \\
\text { most recent } \\
\text { Month examined }\end{array}$ & $\begin{array}{c}\text { Name } \\
\text { Aug } \\
\text { Sep } \\
\text { Oct } \\
\text { Nov } \\
\end{array}$ & $\begin{array}{c}\text { WETS 30th } \\
\text { percentile } \\
0.00 \\
0.00 \\
0.44\end{array}$ & $\begin{array}{c}\text { WETS 70th } \\
\text { percentile } \\
0.00 \\
0.45 \\
1.39\end{array}$ & $\begin{array}{c}\text { Measured } \\
\text { Rainfall } \\
0 \\
0 \\
0\end{array}$ & $\begin{array}{c}\text { Condition } \\
\text { Normal } \\
\text { Normal } \\
\text { Dry }\end{array}$ & $\begin{array}{c}\text { Condition } \\
\text { Value } \\
2 \\
2 \\
1\end{array}$ & $\begin{array}{c}\text { Month } \\
\text { Weight } \\
1 \\
2 \\
3 \\
\text { Total } \\
\end{array}$ & $\begin{array}{c}\text { Score } \\
2 \\
4 \\
3 \\
9 \\
\end{array}$ & Result & $\begin{array}{l}\text { Dry }=6-9 \\
\text { Normal }=10-14 \\
\text { Wet }=15-18\end{array}$ \\
\hline \multicolumn{11}{|l|}{2015} \\
\hline $\begin{array}{l}\quad \text { Prior Month } \\
\text { 3rd } \\
\text { 2nd } \\
\text { most recent } \\
\text { Month examined }\end{array}$ & $\begin{array}{c}\text { Name } \\
\text { Sep } \\
\text { Oct } \\
\text { Nov } \\
\text { Dec } \\
\end{array}$ & $\begin{array}{c}\text { WETS 30th } \\
\text { percentile } \\
0.00 \\
0.44 \\
1.06\end{array}$ & $\begin{array}{c}\text { WETS 70th } \\
\text { percentile } \\
0.45 \\
1.39 \\
3.15\end{array}$ & $\begin{array}{c}\text { Measured } \\
\text { Rainfall } \\
0 \\
0 \\
1.3\end{array}$ & $\begin{array}{c}\text { Condition } \\
\text { Normal } \\
\text { Dry } \\
\text { Normal }\end{array}$ & $\begin{array}{c}\text { Condition } \\
\text { Value } \\
2 \\
1 \\
2\end{array}$ & $\begin{array}{c}\text { Month } \\
\text { Weight } \\
1 \\
2 \\
3 \\
\text { Total } \\
\end{array}$ & $\begin{array}{c}\text { Score } \\
2 \\
2 \\
6 \\
10 \\
\end{array}$ & NORMAL & $\begin{array}{l}\text { Dry }=6-9 \\
\text { Normal }=10-14 \\
\text { Wet }=15-18\end{array}$ \\
\hline \multicolumn{11}{|l|}{2016} \\
\hline $\begin{array}{l}\quad \text { Prior Month } \\
\text { 3rd } \\
\text { 2nd } \\
\text { most recent } \\
\text { Month examined }\end{array}$ & $\begin{array}{c}\text { Name } \\
\text { Oct } \\
\text { Nov } \\
\text { Dec } \\
\text { Jan } \\
\end{array}$ & $\begin{array}{c}\text { WETS 30th } \\
\text { percentile } \\
0.44 \\
1.06 \\
1.00\end{array}$ & $\begin{array}{c}\text { WETS 70th } \\
\text { percentile } \\
1.39 \\
3.15 \\
3.54\end{array}$ & $\begin{array}{c}\text { Measured } \\
\text { Rainfall } \\
0 \\
1.3 \\
0.95\end{array}$ & $\begin{array}{l}\text { Condition } \\
\text { Dry } \\
\text { Normal } \\
\text { Dry }\end{array}$ & $\begin{array}{c}\text { Condition } \\
\text { Value } \\
1 \\
2 \\
1\end{array}$ & $\begin{array}{c}\text { Month } \\
\text { Weight } \\
1 \\
2 \\
3 \\
\text { Total } \\
\end{array}$ & $\begin{array}{c}\text { Score } \\
1 \\
4 \\
3 \\
8 \\
\end{array}$ & Result & $\begin{array}{l}\text { Dry }=6-9 \\
\text { Normal }=10-14 \\
\text { Wet }=15-18\end{array}$ \\
\hline \multicolumn{11}{|l|}{2016} \\
\hline $\begin{array}{l}\quad \text { Prior Month } \\
\text { 3rd } \\
\text { 2nd } \\
\text { most recent } \\
\text { Month examined }\end{array}$ & $\begin{array}{l}\text { Name } \\
\text { Nov } \\
\text { Dec } \\
\text { Jan } \\
\text { Feb } \\
\end{array}$ & $\begin{array}{c}\text { WETS 30th } \\
\text { percentile } \\
1.06 \\
1.00 \\
1.90\end{array}$ & $\begin{array}{c}\text { WETS 70th } \\
\text { percentile } \\
3.15 \\
3.54 \\
4.75\end{array}$ & $\begin{array}{c}\text { Measured } \\
\text { Rainfall } \\
1.3 \\
0.95 \\
4.07\end{array}$ & $\begin{array}{c}\text { Condition } \\
\text { Normal } \\
\text { Dry } \\
\text { Normal }\end{array}$ & $\begin{array}{c}\text { Condition } \\
\text { Value } \\
2 \\
1 \\
2\end{array}$ & $\begin{array}{c}\text { Month } \\
\text { Weight } \\
1 \\
2 \\
3 \\
\text { Total } \\
\end{array}$ & $\begin{array}{c}\text { Score } \\
2 \\
2 \\
6 \\
10 \\
\end{array}$ & NORMAL & $\begin{array}{l}\text { Dry }=6-9 \\
\text { Normal }=10-14 \\
\text { Wet }=15-18\end{array}$ \\
\hline \multicolumn{11}{|l|}{2016} \\
\hline $\begin{array}{l}\quad \text { Prior Month } \\
\text { 3rd } \\
\text { 2nd } \\
\text { most recent } \\
\text { Month examined }\end{array}$ & $\begin{array}{c}\text { Name } \\
\text { Dec } \\
\text { Jan } \\
\text { Feb } \\
\text { Mar } \\
\end{array}$ & $\begin{array}{c}\text { WETS 30th } \\
\text { percentile } \\
1.00 \\
1.90 \\
1.33\end{array}$ & $\begin{array}{c}\text { WETS 70th } \\
\text { percentile } \\
3.54 \\
4.75 \\
4.19\end{array}$ & $\begin{array}{c}\text { Measured } \\
\text { Rainfall } \\
0.95 \\
4.07 \\
0.51\end{array}$ & $\begin{array}{c}\text { Condition } \\
\text { Dry } \\
\text { Normal } \\
\text { Dry }\end{array}$ & $\begin{array}{c}\text { Condition } \\
\text { Value } \\
1 \\
2 \\
1\end{array}$ & $\begin{array}{c}\text { Month } \\
\text { Weight } \\
1 \\
2 \\
3 \\
\text { Total } \\
\end{array}$ & $\begin{array}{c}\text { Score } \\
1 \\
4 \\
3 \\
8 \\
\end{array}$ & DRY & $\begin{array}{l}\text { Dry }=6-9 \\
\text { Normal }=10-14 \\
\text { Wet }=15-18\end{array}$ \\
\hline \multicolumn{11}{|l|}{2016} \\
\hline $\begin{array}{l}\quad \text { Prior Month } \\
\text { 3rd } \\
\text { 2nd } \\
\text { most recent } \\
\text { Month examined } \\
\end{array}$ & $\begin{array}{c}\text { Name } \\
\text { Jan } \\
\text { Feb } \\
\text { Mar } \\
\text { Apr } \\
\end{array}$ & $\begin{array}{c}\text { WETS 30th } \\
\text { percentile } \\
1.90 \\
1.33 \\
1.60\end{array}$ & $\begin{array}{c}\text { WETS 70th } \\
\text { percentile } \\
4.75 \\
4.19 \\
3.90\end{array}$ & $\begin{array}{c}\text { Measured } \\
\text { Rainfall } \\
4.07 \\
0.51 \\
5.9\end{array}$ & $\begin{array}{c}\text { Condition } \\
\text { Normal } \\
\text { Dry } \\
\text { Wet }\end{array}$ & $\begin{array}{c}\text { Condition } \\
\text { Value } \\
2 \\
1 \\
3\end{array}$ & $\begin{array}{c}\text { Month } \\
\text { Weight } \\
1 \\
2 \\
3 \\
\text { Total } \\
\end{array}$ & $\begin{array}{c}\text { Score } \\
2 \\
2 \\
9 \\
\mathbf{1 3} \\
\end{array}$ & NORMAL & $\begin{array}{l}\text { Dry }=6-9 \\
\text { Normal }=10-14 \\
\text { Wet }=15-18\end{array}$ \\
\hline \multicolumn{11}{|l|}{2016} \\
\hline $\begin{array}{l}\quad \text { Prior Month } \\
\text { 3rd } \\
\text { 2nd } \\
\text { most recent } \\
\text { Month examined }\end{array}$ & $\begin{array}{c}\text { Name } \\
\text { Feb } \\
\text { Mar } \\
\text { Apr } \\
\text { May } \\
\end{array}$ & $\begin{array}{c}\text { WETS 30th } \\
\text { percentile } \\
1.33 \\
1.60 \\
0.52\end{array}$ & $\begin{array}{c}\text { WETS 70th } \\
\text { percentile } \\
4.19 \\
3.90 \\
1.54\end{array}$ & $\begin{array}{c}\text { Measured } \\
\text { Rainfall } \\
0.51 \\
5.9 \\
0.27\end{array}$ & $\begin{array}{l}\text { Condition } \\
\text { Dry } \\
\text { Wet } \\
\text { Dry }\end{array}$ & $\begin{array}{c}\text { Condition } \\
\text { Value } \\
1 \\
3 \\
1\end{array}$ & $\begin{array}{c}\text { Month } \\
\text { Weight } \\
1 \\
2 \\
3 \\
\text { Total } \\
\end{array}$ & $\begin{array}{c}\text { Score } \\
1 \\
6 \\
3 \\
10 \\
\end{array}$ & NORMAL & $\begin{array}{l}\text { Dry }=6-9 \\
\text { Normal }=10-14 \\
\text { Wet }=15-18\end{array}$ \\
\hline
\end{tabular}


Study location $G$

\begin{tabular}{|c|c|c|c|c|c|c|c|c|c|c|}
\hline 2015 & & & & & & & & & & \\
\hline $\begin{array}{l}\quad \text { Prior Month } \\
\text { 3rd } \\
\text { 2nd } \\
\text { most recent } \\
\text { Month examined }\end{array}$ & $\begin{array}{l}\text { Name } \\
\text { Sep } \\
\text { Oct } \\
\text { Nov } \\
\text { Dec } \\
\end{array}$ & $\begin{array}{c}\text { WETS 30th } \\
\text { percentile } \\
0.00 \\
0.44 \\
1.06\end{array}$ & $\begin{array}{c}\text { WETS 70th } \\
\text { percentile } \\
0.45 \\
1.39 \\
3.15\end{array}$ & $\begin{array}{c}\text { Measured } \\
\text { Rainfall } \\
0 \\
0.27 \\
1.66\end{array}$ & $\begin{array}{l}\text { Condition } \\
\text { Normal } \\
\text { Dry } \\
\text { Normal }\end{array}$ & $\begin{array}{c}\text { Condition } \\
\text { Value } \\
2 \\
1 \\
2\end{array}$ & $\begin{array}{c}\text { Month } \\
\text { Weight } \\
1 \\
2 \\
3 \\
\text { Total } \\
\end{array}$ & $\begin{array}{c}\text { Score } \\
2 \\
2 \\
6 \\
10 \\
\end{array}$ & NORMAL & $\begin{array}{l}\text { Dry }=6-9 \\
\text { Normal }=10-14 \\
\text { Wet }=15-18\end{array}$ \\
\hline \multicolumn{11}{|l|}{2016} \\
\hline $\begin{array}{l}\text { Prior Month } \\
\text { 3rd } \\
\text { 2nd } \\
\text { most recent } \\
\text { Month examined }\end{array}$ & $\begin{array}{c}\text { Name } \\
\text { Oct } \\
\text { Nov } \\
\text { Dec } \\
\text { Jan } \\
\end{array}$ & $\begin{array}{c}\text { WETS 30th } \\
\text { percentile } \\
0.44 \\
1.06 \\
1.00\end{array}$ & $\begin{array}{c}\text { WETS 70th } \\
\text { percentile } \\
1.39 \\
3.15 \\
3.54\end{array}$ & $\begin{array}{c}\text { Measured } \\
\text { Rainfall } \\
0.27 \\
1.66 \\
1.61\end{array}$ & $\begin{array}{l}\text { Condition } \\
\text { Dry } \\
\text { Normal } \\
\text { Normal }\end{array}$ & $\begin{array}{c}\text { Condition } \\
\text { Value } \\
1 \\
2 \\
2\end{array}$ & $\begin{array}{c}\text { Month } \\
\text { Weight } \\
1 \\
2 \\
3 \\
\text { Total } \\
\end{array}$ & $\begin{array}{c}\text { Score } \\
1 \\
4 \\
6 \\
11 \\
\end{array}$ & NORMAL & $\begin{array}{l}\text { Dry }=6-9 \\
\text { Normal }=10-14 \\
\text { Wet }=15-18\end{array}$ \\
\hline \multicolumn{11}{|l|}{2016} \\
\hline $\begin{array}{l}\quad \text { Prior Month } \\
\text { 3rd } \\
\text { 2nd } \\
\text { most recent } \\
\text { Month examined }\end{array}$ & $\begin{array}{l}\text { Name } \\
\text { Nov } \\
\text { Dec } \\
\text { Jan } \\
\text { Feb } \\
\end{array}$ & $\begin{array}{c}\text { WETS 30th } \\
\text { percentile } \\
1.06 \\
1.00 \\
1.90\end{array}$ & $\begin{array}{c}\text { WETS 70th } \\
\text { percentile } \\
3.15 \\
3.54 \\
4.75\end{array}$ & $\begin{array}{c}\text { Measured } \\
\text { Rainfall } \\
1.66 \\
1.61 \\
5.76\end{array}$ & $\begin{array}{c}\text { Condition } \\
\text { Normal } \\
\text { Normal } \\
\text { Wet }\end{array}$ & $\begin{array}{c}\text { Condition } \\
\text { Value } \\
2 \\
2 \\
3\end{array}$ & $\begin{array}{c}\text { Month } \\
\text { Weight } \\
1 \\
2 \\
3 \\
\text { Total } \\
\end{array}$ & $\begin{array}{c}\text { Score } \\
2 \\
4 \\
9 \\
15 \\
\end{array}$ & Result & $\begin{array}{l}\text { Dry }=6-9 \\
\text { Normal }=10-14 \\
\text { Wet }=15-18\end{array}$ \\
\hline \multicolumn{11}{|l|}{2016} \\
\hline $\begin{array}{l}\quad \text { Prior Month } \\
\text { 3rd } \\
\text { 2nd } \\
\text { most recent } \\
\text { Month examined } \\
\end{array}$ & $\begin{array}{c}\text { Name } \\
\text { Dec } \\
\text { Jan } \\
\text { Feb } \\
\text { Mar } \\
\end{array}$ & $\begin{array}{c}\text { WETS 30th } \\
\text { percentile } \\
1.00 \\
1.90 \\
1.33\end{array}$ & $\begin{array}{c}\text { WETS 70th } \\
\text { percentile } \\
3.54 \\
4.75 \\
4.19\end{array}$ & $\begin{array}{c}\text { Measured } \\
\text { Rainfall } \\
1.61 \\
5.76 \\
0.57\end{array}$ & $\begin{array}{c}\text { Condition } \\
\text { Normal } \\
\text { Wet } \\
\text { Dry }\end{array}$ & $\begin{array}{c}\text { Condition } \\
\text { Value } \\
2 \\
3 \\
1\end{array}$ & $\begin{array}{c}\text { Month } \\
\text { Weight } \\
1 \\
2 \\
3 \\
\text { Total } \\
\end{array}$ & $\begin{array}{c}\text { Score } \\
2 \\
6 \\
3 \\
11 \\
\end{array}$ & NORMAL & $\begin{array}{l}\text { Dry }=6-9 \\
\text { Normal }=10-14 \\
\text { Wet }=15-18\end{array}$ \\
\hline \multicolumn{11}{|l|}{2016} \\
\hline $\begin{array}{l}\quad \text { Prior Month } \\
\text { 3rd } \\
\text { 2nd } \\
\text { most recent } \\
\text { Month examined }\end{array}$ & $\begin{array}{l}\text { Name } \\
\text { Jan } \\
\text { Feb } \\
\text { Mar } \\
\text { Apr } \\
\end{array}$ & $\begin{array}{c}\text { WETS 30th } \\
\text { percentile } \\
1.90 \\
1.33 \\
1.60\end{array}$ & $\begin{array}{c}\text { WETS 70th } \\
\text { percentile } \\
4.75 \\
4.19 \\
3.90\end{array}$ & $\begin{array}{c}\text { Measured } \\
\text { Rainfall } \\
4.22 \\
0.57 \\
3.14\end{array}$ & $\begin{array}{l}\text { Condition } \\
\text { Normal } \\
\text { Dry } \\
\text { Normal }\end{array}$ & $\begin{array}{c}\text { Condition } \\
\text { Value } \\
2 \\
1 \\
2\end{array}$ & $\begin{array}{c}\text { Month } \\
\text { Weight } \\
1 \\
2 \\
3 \\
\text { Total } \\
\end{array}$ & $\begin{array}{c}\text { Score } \\
2 \\
2 \\
6 \\
10 \\
\end{array}$ & NORMAL & $\begin{array}{l}\text { Dry }=6-9 \\
\text { Normal }=10-14 \\
\text { Wet }=15-18\end{array}$ \\
\hline \multicolumn{11}{|l|}{2016} \\
\hline $\begin{array}{l}\quad \text { Prior Month } \\
\text { 3rd } \\
\text { 2nd } \\
\text { most recent } \\
\text { Month examined }\end{array}$ & $\begin{array}{l}\text { Name } \\
\text { Feb } \\
\text { Mar } \\
\text { Apr } \\
\text { May }\end{array}$ & $\begin{array}{c}\text { WETS 30th } \\
\text { percentile } \\
1.33 \\
1.60 \\
0.52\end{array}$ & $\begin{array}{c}\text { WETS 70th } \\
\text { percentile } \\
4.19 \\
3.90 \\
1.54\end{array}$ & $\begin{array}{c}\text { Measured } \\
\text { Rainfall } \\
0.57 \\
3.14 \\
0.14\end{array}$ & $\begin{array}{l}\text { Condition } \\
\text { Dry } \\
\text { Normal } \\
\text { Dry }\end{array}$ & $\begin{array}{c}\text { Condition } \\
\text { Value } \\
1 \\
2 \\
1\end{array}$ & $\begin{array}{c}\text { Month } \\
\text { Weight } \\
1 \\
2 \\
3 \\
\text { Total } \\
\end{array}$ & $\begin{array}{c}\text { Score } \\
1 \\
4 \\
3 \\
8 \\
\end{array}$ & Result & $\begin{array}{l}\text { Dry }=6-9 \\
\text { Normal }=10-14 \\
\text { Wet }=15-18\end{array}$ \\
\hline
\end{tabular}


Study location N

\begin{tabular}{|c|c|c|c|c|c|c|c|c|c|c|}
\hline 2015 & & & & & & & & & & \\
\hline $\begin{array}{l}\quad \text { Prior Month } \\
\text { 3rd } \\
\text { 2nd } \\
\text { most recent } \\
\text { Month examined } \\
\end{array}$ & $\begin{array}{l}\text { Name } \\
\text { Sep } \\
\text { Oct } \\
\text { Nov } \\
\text { Dec } \\
\end{array}$ & $\begin{array}{c}\text { WETS 30th } \\
\text { percentile } \\
0.00 \\
0.44 \\
1.06\end{array}$ & $\begin{array}{c}\text { WETS 70th } \\
\text { percentile } \\
0.45 \\
1.39 \\
3.15\end{array}$ & $\begin{array}{c}\text { Measured } \\
\text { Rainfall } \\
0 \\
0 \\
1.3\end{array}$ & $\begin{array}{l}\text { Condition } \\
\text { Normal } \\
\text { Dry } \\
\text { Normal }\end{array}$ & $\begin{array}{c}\text { Condition } \\
\text { Value } \\
2 \\
1 \\
2\end{array}$ & $\begin{array}{c}\text { Month } \\
\text { Weight } \\
1 \\
2 \\
3 \\
\text { Total } \\
\end{array}$ & $\begin{array}{c}\text { Score } \\
2 \\
2 \\
6 \\
10 \\
\end{array}$ & Result & $\begin{array}{l}\text { Dry }=6-9 \\
\text { Normal }=10-14 \\
\text { Wet }=15-18\end{array}$ \\
\hline \multicolumn{11}{|l|}{2016} \\
\hline $\begin{array}{l}\quad \text { Prior Month } \\
\text { 3rd } \\
\text { 2nd } \\
\text { most recent } \\
\text { Month examined }\end{array}$ & $\begin{array}{c}\text { Name } \\
\text { Oct } \\
\text { Nov } \\
\text { Dec } \\
\text { Jan } \\
\end{array}$ & $\begin{array}{c}\text { WETS 30th } \\
\text { percentile } \\
0.44 \\
1.06 \\
1.00\end{array}$ & $\begin{array}{c}\text { WETS 70th } \\
\text { percentile } \\
1.39 \\
3.15 \\
3.54\end{array}$ & $\begin{array}{c}\text { Measured } \\
\text { Rainfall } \\
0 \\
1.3 \\
0.95\end{array}$ & $\begin{array}{l}\text { Condition } \\
\text { Dry } \\
\text { Normal } \\
\text { Dry }\end{array}$ & $\begin{array}{c}\text { Condition } \\
\text { Value } \\
1 \\
2 \\
1\end{array}$ & $\begin{array}{c}\text { Month } \\
\text { Weight } \\
1 \\
2 \\
3 \\
\text { Total } \\
\end{array}$ & $\begin{array}{c}\text { Score } \\
1 \\
4 \\
3 \\
8 \\
\end{array}$ & Result & $\begin{array}{l}\text { Dry }=6-9 \\
\text { Normal }=10-14 \\
\text { Wet }=15-18\end{array}$ \\
\hline \multicolumn{11}{|l|}{2016} \\
\hline $\begin{array}{l}\quad \text { Prior Month } \\
\text { 3rd } \\
\text { 2nd } \\
\text { most recent } \\
\text { Month examined } \\
\end{array}$ & $\begin{array}{l}\text { Name } \\
\text { Nov } \\
\text { Dec } \\
\text { Jan } \\
\text { Feb } \\
\end{array}$ & $\begin{array}{c}\text { WETS 30th } \\
\text { percentile } \\
1.06 \\
1.00 \\
1.90\end{array}$ & $\begin{array}{c}\text { WETS70th } \\
\text { percentile } \\
3.15 \\
3.54 \\
4.75\end{array}$ & $\begin{array}{c}\text { Measured } \\
\text { Rainfall } \\
1.3 \\
0.95 \\
4.07\end{array}$ & $\begin{array}{l}\text { Condition } \\
\text { Normal } \\
\text { Dry } \\
\text { Normal }\end{array}$ & $\begin{array}{c}\text { Condition } \\
\text { Value } \\
2 \\
1 \\
2\end{array}$ & $\begin{array}{c}\text { Month } \\
\text { Weight } \\
1 \\
2 \\
3 \\
\text { Total } \\
\end{array}$ & $\begin{array}{c}\text { Score } \\
2 \\
2 \\
6 \\
10 \\
\end{array}$ & NORMAL & $\begin{array}{l}\text { Dry }=6-9 \\
\text { Normal }=10-14 \\
\text { Wet }=15-18\end{array}$ \\
\hline $\begin{array}{l}\quad \text { Prior Month } \\
\text { 3rd } \\
\text { 2nd } \\
\text { most recent } \\
\text { Month examined }\end{array}$ & $\begin{array}{l}\text { Name } \\
\text { Dec } \\
\text { Jan } \\
\text { Feb } \\
\text { Mar } \\
\end{array}$ & $\begin{array}{c}\text { WETS 30th } \\
\text { percentile } \\
1.00 \\
1.90 \\
1.33\end{array}$ & $\begin{array}{c}\text { WETS 70th } \\
\text { percentile } \\
3.54 \\
4.75 \\
4.19\end{array}$ & $\begin{array}{c}\text { Measured } \\
\text { Rainfall } \\
0.95 \\
4.07 \\
0.51\end{array}$ & $\begin{array}{l}\text { Condition } \\
\text { Dry } \\
\text { Normal } \\
\text { Dry }\end{array}$ & $\begin{array}{c}\text { Condition } \\
\text { Value } \\
1 \\
2 \\
1\end{array}$ & $\begin{array}{c}\text { Month } \\
\text { Weight } \\
1 \\
2 \\
3 \\
\text { Total } \\
\end{array}$ & $\begin{array}{c}\text { Score } \\
1 \\
4 \\
3 \\
8 \\
\end{array}$ & Result & $\begin{array}{l}\text { Dry }=6-9 \\
\text { Normal }=10-14 \\
\text { Wet }=15-18\end{array}$ \\
\hline \multicolumn{11}{|l|}{2016} \\
\hline $\begin{array}{l}\quad \text { Prior Month } \\
\text { 3rd } \\
\text { 2nd } \\
\text { most recent } \\
\text { Month examined } \\
\end{array}$ & $\begin{array}{l}\text { Name } \\
\text { Jan } \\
\text { Feb } \\
\text { Mar } \\
\text { Apr } \\
\end{array}$ & $\begin{array}{c}\text { WETS 30th } \\
\text { percentile } \\
1.90 \\
1.33 \\
1.60\end{array}$ & $\begin{array}{c}\text { WETS 70th } \\
\text { percentile } \\
4.75 \\
4.19 \\
3.90\end{array}$ & $\begin{array}{c}\text { Measured } \\
\text { Rainfall } \\
4.07 \\
0.51 \\
5.95\end{array}$ & $\begin{array}{c}\text { Condition } \\
\text { Normal } \\
\text { Dry } \\
\text { Wet }\end{array}$ & $\begin{array}{c}\text { Condition } \\
\text { Value } \\
2 \\
1 \\
3\end{array}$ & $\begin{array}{c}\text { Month } \\
\text { Weight } \\
1 \\
2 \\
3 \\
\text { Total } \\
\end{array}$ & $\begin{array}{c}\text { Score } \\
2 \\
2 \\
9 \\
13 \\
\end{array}$ & NORMAL & $\begin{array}{l}\text { Dry }=6-9 \\
\text { Normal }=10-14 \\
\text { Wet }=15-18\end{array}$ \\
\hline \multicolumn{11}{|l|}{2016} \\
\hline $\begin{array}{l}\quad \text { Prior Month } \\
\text { 3rd } \\
\text { 2nd } \\
\text { most recent } \\
\text { Month examined }\end{array}$ & $\begin{array}{l}\text { Name } \\
\text { Feb } \\
\text { Mar } \\
\text { Apr } \\
\text { May }\end{array}$ & $\begin{array}{c}\text { WETS 30th } \\
\text { percentile } \\
1.33 \\
1.60 \\
0.52\end{array}$ & $\begin{array}{c}\text { WETS 70th } \\
\text { percentile } \\
4.19 \\
3.90 \\
1.54\end{array}$ & $\begin{array}{c}\text { Measured } \\
\text { Rainfall } \\
0.51 \\
5.95 \\
0.71\end{array}$ & $\begin{array}{c}\text { Condition } \\
\text { Dry } \\
\text { Wet } \\
\text { Normal }\end{array}$ & $\begin{array}{c}\text { Condition } \\
\text { Value } \\
1 \\
3 \\
2\end{array}$ & $\begin{array}{c}\text { Month } \\
\text { Weight } \\
1 \\
2 \\
3 \\
\text { Total } \\
\end{array}$ & $\begin{array}{c}\text { Score } \\
1 \\
6 \\
6 \\
13 \\
\end{array}$ & NORMAL & $\begin{array}{l}\text { Dry }=6-9 \\
\text { Normal }=10-14 \\
\text { Wet }=15-18\end{array}$ \\
\hline
\end{tabular}


Study location $\mathrm{R}$

\begin{tabular}{|c|c|c|c|c|c|c|c|c|c|c|}
\hline $\begin{array}{l}\quad \text { Prior Month } \\
\text { 3rd } \\
\text { 2nd } \\
\text { most recent } \\
\text { Month examined } \\
\end{array}$ & $\begin{array}{l}\text { Name } \\
\text { Sep } \\
\text { Oct } \\
\text { Nov } \\
\text { Dec } \\
\end{array}$ & $\begin{array}{c}\text { WETS 30th } \\
\text { percentile } \\
0.00 \\
0.44 \\
1.06\end{array}$ & $\begin{array}{c}\text { WETS 70th } \\
\text { percentile } \\
0.45 \\
1.39 \\
3.15\end{array}$ & $\begin{array}{c}\text { Measured } \\
\text { Rainfall } \\
0 \\
0 \\
0.09\end{array}$ & $\begin{array}{l}\text { Condition } \\
\text { Normal } \\
\text { Dry } \\
\text { Dry }\end{array}$ & $\begin{array}{c}\text { Condition } \\
\text { Value } \\
2 \\
1 \\
1\end{array}$ & $\begin{array}{c}\text { Month } \\
\text { Weight } \\
1 \\
2 \\
3 \\
\text { Total } \\
\end{array}$ & $\begin{array}{c}\text { Score } \\
2 \\
2 \\
3 \\
7 \\
\end{array}$ & Result & $\begin{array}{l}\text { Dry }=6-9 \\
\text { Normal }=10-14 \\
\text { Wet }=15-18\end{array}$ \\
\hline \multicolumn{11}{|l|}{2016} \\
\hline $\begin{array}{l}\text { Prior Month } \\
\text { 3rd } \\
\text { 2nd } \\
\text { most recent } \\
\text { Month examined }\end{array}$ & $\begin{array}{l}\text { Name } \\
\text { Oct } \\
\text { Nov } \\
\text { Dec } \\
\text { Jan } \\
\end{array}$ & $\begin{array}{c}\text { WETS 30th } \\
\text { percentile } \\
0.44 \\
1.06 \\
1.00\end{array}$ & $\begin{array}{c}\text { WETS 70th } \\
\text { percentile } \\
1.39 \\
3.15 \\
3.54\end{array}$ & $\begin{array}{c}\text { Measured } \\
\text { Rainfall } \\
0 \\
0.09 \\
1.96\end{array}$ & $\begin{array}{l}\text { Condition } \\
\text { Dry } \\
\text { Dry } \\
\text { Normal }\end{array}$ & $\begin{array}{c}\text { Condition } \\
\text { Value } \\
1 \\
1 \\
2\end{array}$ & $\begin{array}{c}\text { Month } \\
\text { Weight } \\
1 \\
2 \\
3 \\
\text { Total } \\
\end{array}$ & $\begin{array}{c}\text { Score } \\
1 \\
2 \\
6 \\
9 \\
\end{array}$ & Result & $\begin{array}{l}\text { Dry }=6-9 \\
\text { Normal }=10-14 \\
\text { Wet }=15-18\end{array}$ \\
\hline \multicolumn{11}{|l|}{2016} \\
\hline $\begin{array}{l}\text { Prior Month } \\
\text { 3rd } \\
\text { 2nd } \\
\text { most recent } \\
\text { Month examined } \\
\end{array}$ & $\begin{array}{l}\text { Name } \\
\text { Nov } \\
\text { Dec } \\
\text { Jan } \\
\text { Feb } \\
\end{array}$ & $\begin{array}{c}\text { WETS30th } \\
\text { percentile } \\
1.06 \\
1.00 \\
1.90\end{array}$ & $\begin{array}{c}\text { WETS 70th } \\
\text { percentile } \\
3.15 \\
3.54 \\
4.75\end{array}$ & $\begin{array}{c}\text { Measured } \\
\text { Rainfall } \\
0.09 \\
1.98 \\
4.74\end{array}$ & $\begin{array}{l}\text { Condition } \\
\text { Dry } \\
\text { Normal } \\
\text { Normal }\end{array}$ & $\begin{array}{c}\text { Condition } \\
\text { Value } \\
1 \\
2 \\
2\end{array}$ & $\begin{array}{c}\text { Month } \\
\text { Weight } \\
1 \\
2 \\
3 \\
\text { Total } \\
\end{array}$ & $\begin{array}{c}\text { Score } \\
1 \\
4 \\
6 \\
11 \\
\end{array}$ & NORMAL & $\begin{array}{l}\text { Dry }=6-9 \\
\text { Normal }=10-14 \\
\text { Wet }=15-18\end{array}$ \\
\hline \multicolumn{11}{|l|}{2016} \\
\hline $\begin{array}{l}\quad \text { Prior Month } \\
\text { 3rd } \\
\text { 2nd } \\
\text { most recent } \\
\text { Month examined } \\
\end{array}$ & $\begin{array}{l}\text { Name } \\
\text { Dec } \\
\text { Jan } \\
\text { Feb } \\
\text { Mar } \\
\end{array}$ & $\begin{array}{c}\text { WETS 30th } \\
\text { percentile } \\
1.00 \\
1.90 \\
1.33\end{array}$ & $\begin{array}{c}\text { WETS 70th } \\
\text { percentile } \\
3.54 \\
4.75 \\
4.19\end{array}$ & $\begin{array}{c}\text { Measured } \\
\text { Rainfall } \\
1.98 \\
4.74 \\
0.92\end{array}$ & $\begin{array}{l}\text { Condition } \\
\text { Normal } \\
\text { Normal } \\
\text { Dry }\end{array}$ & $\begin{array}{c}\text { Condition } \\
\text { Value } \\
2 \\
2 \\
1\end{array}$ & $\begin{array}{c}\text { Month } \\
\text { Weight } \\
1 \\
2 \\
3 \\
\text { Total } \\
\end{array}$ & $\begin{array}{c}\text { Score } \\
2 \\
4 \\
3 \\
9 \\
\end{array}$ & DRY & $\begin{array}{l}\text { Dry }=6-9 \\
\text { Normal }=10-14 \\
\text { Wet }=15-18\end{array}$ \\
\hline \multicolumn{11}{|c|}{ 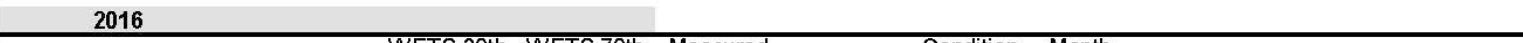 } \\
\hline $\begin{array}{l}\quad \text { Prior Month } \\
\text { 3rd } \\
\text { 2nd } \\
\text { most recent } \\
\text { Month examined }\end{array}$ & $\begin{array}{l}\text { Name } \\
\text { Jan } \\
\text { Feb } \\
\text { Mar } \\
\text { Apr } \\
\end{array}$ & $\begin{array}{c}\text { WETS 30th } \\
\text { percentile } \\
1.90 \\
1.33 \\
1.60\end{array}$ & $\begin{array}{c}\text { WETS 70th } \\
\text { percentile } \\
4.75 \\
4.19 \\
3.90\end{array}$ & $\begin{array}{c}\text { Measured } \\
\text { Rainfall } \\
4.74 \\
0.92 \\
6.04\end{array}$ & $\begin{array}{l}\text { Condition } \\
\text { Normal } \\
\text { Dry } \\
\text { Wet }\end{array}$ & $\begin{array}{c}\text { Condition } \\
\text { Value } \\
2 \\
1 \\
3\end{array}$ & $\begin{array}{c}\text { Month } \\
\text { Weight } \\
1 \\
2 \\
3 \\
\text { Total } \\
\end{array}$ & $\begin{array}{c}\text { Score } \\
2 \\
2 \\
9 \\
\mathbf{1 3} \\
\end{array}$ & NORMAL & $\begin{array}{l}\text { Dry }=6-9 \\
\text { Normal }=10-14 \\
\text { Wet }=15-18\end{array}$ \\
\hline \multicolumn{11}{|l|}{2016} \\
\hline $\begin{array}{l}\quad \text { Prior Month } \\
\text { 3rd } \\
\text { 2nd } \\
\text { most recent } \\
\text { Month examined }\end{array}$ & $\begin{array}{l}\text { Name } \\
\text { Feb } \\
\text { Mar } \\
\text { Apr } \\
\text { May } \\
\end{array}$ & $\begin{array}{c}\text { WETS 30th } \\
\text { percentile } \\
1.33 \\
1.60 \\
0.52\end{array}$ & $\begin{array}{c}\text { WETS 70th } \\
\text { percentile } \\
4.19 \\
3.90 \\
1.54\end{array}$ & $\begin{array}{c}\text { Measured } \\
\text { Rainfall } \\
0.92 \\
6.04 \\
0.93\end{array}$ & $\begin{array}{c}\text { Condition } \\
\text { Dry } \\
\text { Wet } \\
\text { Normal }\end{array}$ & $\begin{array}{c}\text { Condition } \\
\text { Value } \\
1 \\
3 \\
2\end{array}$ & $\begin{array}{c}\text { Month } \\
\text { Weight } \\
1 \\
2 \\
3 \\
\text { Total } \\
\end{array}$ & $\begin{array}{c}\text { Score } \\
1 \\
6 \\
6 \\
13 \\
\end{array}$ & NORMAL & $\begin{array}{l}\text { Dry }=6-9 \\
\text { Normal }=10-14 \\
\text { Wet }=15-18\end{array}$ \\
\hline
\end{tabular}


Study location T

\begin{tabular}{|c|c|c|c|c|c|c|c|c|c|c|}
\hline $\begin{array}{l}\quad \text { Prior Month } \\
\text { 3rd } \\
\text { 2nd } \\
\text { most recent } \\
\text { Month examined } \\
\end{array}$ & $\begin{array}{l}\text { Name } \\
\text { Sep } \\
\text { Oct } \\
\text { Nov } \\
\text { Dec } \\
\end{array}$ & $\begin{array}{c}\text { WETS 30th } \\
\text { percentile } \\
0.00 \\
0.44 \\
1.06\end{array}$ & $\begin{array}{c}\text { WETS 70th } \\
\text { percentile } \\
0.45 \\
1.39 \\
3.15\end{array}$ & $\begin{array}{c}\text { Measured } \\
\text { Rainfall } \\
0 \\
0 \\
0.09\end{array}$ & $\begin{array}{c}\text { Condition } \\
\text { Normal } \\
\text { Dry } \\
\text { Dry }\end{array}$ & $\begin{array}{c}\text { Condition } \\
\text { Value } \\
2 \\
1 \\
1\end{array}$ & $\begin{array}{c}\text { Month } \\
\text { Weight } \\
1 \\
2 \\
3 \\
\text { Total } \\
\end{array}$ & $\begin{array}{c}\text { Score } \\
2 \\
2 \\
3 \\
7 \\
\end{array}$ & Result & $\begin{array}{l}\text { Dry }=6-9 \\
\text { Normal }=10-14 \\
\text { Wet }=15-18\end{array}$ \\
\hline \multicolumn{11}{|l|}{2016} \\
\hline $\begin{array}{l}\quad \text { Prior Month } \\
\text { 3rd } \\
\text { 2nd } \\
\text { most recent } \\
\text { Month examined }\end{array}$ & $\begin{array}{l}\text { Name } \\
\text { Oct } \\
\text { Nov } \\
\text { Dec } \\
\text { Jan } \\
\end{array}$ & $\begin{array}{c}\text { WETS 30th } \\
\text { percentile } \\
0.44 \\
1.06 \\
1.00\end{array}$ & $\begin{array}{c}\text { WETS 70th } \\
\text { percentile } \\
1.39 \\
3.15 \\
3.54\end{array}$ & $\begin{array}{c}\text { Measured } \\
\text { Rainfall } \\
0 \\
0.09 \\
1.83\end{array}$ & $\begin{array}{c}\text { Condition } \\
\text { Dry } \\
\text { Dry } \\
\text { Normal }\end{array}$ & $\begin{array}{c}\text { Condition } \\
\text { Value } \\
1 \\
1 \\
2\end{array}$ & $\begin{array}{c}\text { Month } \\
\text { Weight } \\
1 \\
2 \\
3 \\
\text { Total } \\
\end{array}$ & $\begin{array}{c}\text { Score } \\
1 \\
2 \\
6 \\
9 \\
\end{array}$ & Result & $\begin{array}{l}\text { Dry }=6-9 \\
\text { Normal }=10-14 \\
\text { Wet }=15-18\end{array}$ \\
\hline \multicolumn{11}{|l|}{2016} \\
\hline $\begin{array}{l}\quad \text { Prior Month } \\
\text { 3rd } \\
\text { 2nd } \\
\text { most recent } \\
\text { Month examined }\end{array}$ & $\begin{array}{l}\text { Name } \\
\text { Nov } \\
\text { Dec } \\
\text { Jan } \\
\text { Feb } \\
\end{array}$ & $\begin{array}{c}\text { WETS 30th } \\
\text { percentile } \\
1.06 \\
1.00 \\
1.90\end{array}$ & $\begin{array}{c}\text { WETS70th } \\
\text { percentile } \\
3.15 \\
3.54 \\
4.75\end{array}$ & $\begin{array}{c}\text { Measured } \\
\text { Rainfall } \\
0.09 \\
1.83 \\
4.22\end{array}$ & $\begin{array}{c}\text { Condition } \\
\text { Dry } \\
\text { Normal } \\
\text { Normal }\end{array}$ & $\begin{array}{c}\text { Condition } \\
\text { Value } \\
1 \\
2 \\
2\end{array}$ & $\begin{array}{c}\text { Month } \\
\text { Weight } \\
1 \\
2 \\
3 \\
\text { Total } \\
\end{array}$ & $\begin{array}{c}\text { Score } \\
1 \\
4 \\
6 \\
11 \\
\end{array}$ & NORMAL & $\begin{array}{l}\text { Dry }=6-9 \\
\text { Normal }=10-14 \\
\text { Wet }=15-18\end{array}$ \\
\hline \multicolumn{11}{|l|}{2016} \\
\hline $\begin{array}{l}\quad \text { Prior Month } \\
\text { 3rd } \\
\text { 2nd } \\
\text { most recent } \\
\text { Month examined } \\
\end{array}$ & $\begin{array}{l}\text { Name } \\
\text { Dec } \\
\text { Jan } \\
\text { Feb } \\
\text { Mar } \\
\end{array}$ & $\begin{array}{c}\text { WETS 30th } \\
\text { percentile } \\
1.00 \\
1.90 \\
1.33\end{array}$ & $\begin{array}{c}\text { WETS 70th } \\
\text { percentile } \\
3.54 \\
4.75 \\
4.19\end{array}$ & $\begin{array}{c}\text { Measured } \\
\text { Rainfall } \\
1.83 \\
4.22 \\
0.9\end{array}$ & $\begin{array}{c}\text { Condition } \\
\text { Normal } \\
\text { Normal } \\
\text { Dry }\end{array}$ & $\begin{array}{c}\text { Condition } \\
\text { Value } \\
2 \\
2 \\
1\end{array}$ & $\begin{array}{c}\text { Month } \\
\text { Weight } \\
1 \\
2 \\
3 \\
\text { Total } \\
\end{array}$ & $\begin{array}{c}\text { Score } \\
2 \\
4 \\
3 \\
9 \\
\end{array}$ & Result & $\begin{array}{l}\text { Dry }=6-9 \\
\text { Normal }=10-14 \\
\text { Wet }=15-18\end{array}$ \\
\hline \multicolumn{11}{|l|}{2016} \\
\hline $\begin{array}{l}\quad \text { Prior Month } \\
\text { 3rd } \\
\text { 2nd } \\
\text { most recent } \\
\text { Month examined } \\
\end{array}$ & $\begin{array}{l}\text { Name } \\
\text { Jan } \\
\text { Feb } \\
\text { Mar } \\
\text { Apr } \\
\end{array}$ & $\begin{array}{c}\text { WETS 30th } \\
\text { percentile } \\
1.90 \\
1.33 \\
1.60\end{array}$ & $\begin{array}{c}\text { WETS 70th } \\
\text { percentile } \\
4.75 \\
4.19 \\
3.90\end{array}$ & $\begin{array}{c}\text { Measured } \\
\text { Rainfall } \\
4.22 \\
0.9 \\
3.6\end{array}$ & $\begin{array}{c}\text { Condition } \\
\text { Normal } \\
\text { Dry } \\
\text { Normal }\end{array}$ & $\begin{array}{c}\text { Condition } \\
\text { Value } \\
2 \\
1 \\
2\end{array}$ & $\begin{array}{c}\text { Month } \\
\text { Weight } \\
1 \\
2 \\
3 \\
\text { Total } \\
\end{array}$ & $\begin{array}{c}\text { Score } \\
2 \\
2 \\
6 \\
10 \\
\end{array}$ & NORMAL & $\begin{array}{l}\text { Dry }=6-9 \\
\text { Normal }=10-14 \\
\text { Wet }=15-18\end{array}$ \\
\hline \multicolumn{11}{|l|}{2016} \\
\hline $\begin{array}{l}\quad \text { Prior Month } \\
\text { 3rd } \\
\text { 2nd } \\
\text { most recent } \\
\text { Month examined }\end{array}$ & $\begin{array}{l}\text { Name } \\
\text { Feb } \\
\text { Mar } \\
\text { Apr } \\
\text { May } \\
\end{array}$ & $\begin{array}{c}\text { WETS 30th } \\
\text { percentile } \\
1.33 \\
1.60 \\
0.52\end{array}$ & $\begin{array}{c}\text { WETS 70th } \\
\text { percentile } \\
4.19 \\
3.90 \\
1.54\end{array}$ & $\begin{array}{c}\text { Measured } \\
\text { Rainfall } \\
0.9 \\
3.6 \\
1.13\end{array}$ & $\begin{array}{c}\text { Condition } \\
\text { Dry } \\
\text { Normal } \\
\text { Normal }\end{array}$ & $\begin{array}{c}\text { Condition } \\
\text { Value } \\
1 \\
2 \\
2\end{array}$ & $\begin{array}{c}\text { Month } \\
\text { Weight } \\
1 \\
2 \\
3 \\
\text { Total } \\
\end{array}$ & $\begin{array}{c}\text { Score } \\
1 \\
4 \\
6 \\
11 \\
\end{array}$ & NORMAL & $\begin{array}{l}\text { Dry }=6-9 \\
\text { Normal }=10-14 \\
\text { Wet }=15-18\end{array}$ \\
\hline
\end{tabular}




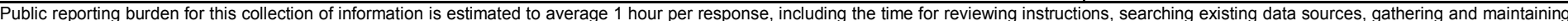

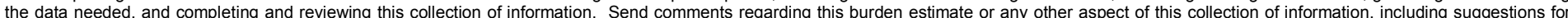

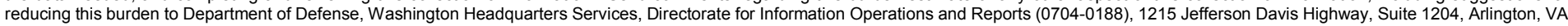

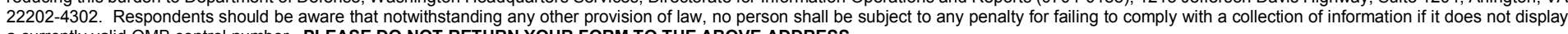
a currently valid OMB control number. PLEASE DO NOT RETURN YOUR FORM TO THE ABOVE ADDRESS.

\begin{tabular}{l|l} 
1. REPORT DATE (DD-MM-YYYY) & 2. REPORT TYPE
\end{tabular} July 2017 Final report

3. DATES COVERED (From - To)

\section{TITLE AND SUBTITLE}

Evaluation of Wetland Hydrology in Formerly Irrigated Areas

5a. CONTRACT NUMBER

5b. GRANT NUMBER

5c. PROGRAM ELEMENT NUMBER

\section{AUTHOR(S)}

Jacob F. Berkowitz, Jason P. Pietroski, and Steven J. Currie

\section{5d. PROJECT NUMBER}

A1360

5e. TASK NUMBER

\section{5f. WORK UNIT NUMBER}

8. PERFORMING ORGANIZATION REPORT NUMBER

ERDC/EL TR-17-13

U.S. Army Engineer Research and Development Center

Environmental Laboratory

3909 Halls Ferry Road

Vicksburg, MS 39180-6199

9. SPONSORING / MONITORING AGENCY NAME(S) AND ADDRESS(ES)

Headquarters, U.S. Army Corps of Engineers

Washington, DC 20314-1000
10. SPONSOR/MONITOR'S ACRONYM(S)

11. SPONSOR/MONITOR'S REPORT NUMBER(S)

\section{DISTRIBUTION / AVAILABILITY STATEMENT}

Approved for public release; distribution unlimited.

\section{SUPPLEMENTARY NOTES}

\section{ABSTRACT}

The application of irrigation waters has the potential to alter soil morphology, patterns of hydrology, and the distribution of plant communities. As a result, the identification of wetlands in irrigated areas remains challenging. The following report is the first to evaluate the capacity of wetland hydrology to persist following the cessation of external water inputs for the purposes of wetland identification. Twelve of the thirteen study locations examined met the established criteria for wetland identification. The spatial extent of wetland hydrology was determined on-site and compared to estimates based upon an analysis of aerial imagery. Findings suggest that aerial image interpretation provides a useful, but conservative approach to identifying areas of wetland hydrology in formerly irrigated areas. A framework is proposed to support wetland delineations conducted in formerly irrigated areas incorporating off-site evaluations, site visits conducted during the regular wet portion of the year, and analysis of rainfall normality.

\begin{tabular}{lll}
\hline 15. SUBJECT TERMS & Wetland surveys & Soil structure--Effect of irrigation on \\
Wetlands & Irrigation farming & Plant communities--Effect of irrigation on \\
Wetland hydrology & Rain and rainfall--Effect of irrigation on & Aerial photography
\end{tabular}

16. SECURITY CLASSIFICATION OF:

\begin{tabular}{|l|l|l|}
\hline a. REPORT & b. ABSTRACT & c. THIS PAGE \\
UNCLASSIFIED & UNCLASSIFIED & UNCLASSIFIED \\
\hline
\end{tabular}

17. LIMITATION
OF ABSTRACT

\begin{tabular}{c|l}
$\begin{array}{c}\text { 18. NUMBER } \\
\text { OF PAGES }\end{array}$ & $\begin{array}{l}\text { 19a. NAME OF RESPONSIBLE } \\
\text { PERSON }\end{array}$ \\
\cline { 2 - 2 } 60 & $\begin{array}{l}\text { 19b. TELEPHONE NUMBER (include } \\
\text { area code) }\end{array}$ \\
\hline
\end{tabular}

Standard Form 298 (Rev. 8-98) 